\title{
A quantitative Study of Variation, Natural and Induced, in pure Lines of Silene Noctiflora ${ }^{1}$.
}

Eugene P. Humbert, M. S. in Agr.

The subject matter of this paper is based upon a study, through three generations, of a pure line of Silene noctiflora. For the statistical data about seven thousand five hundred plants have been measured for the following characters: height of plant, width of plant, number of branches per plant, and number of seed pods (capsules) per plant. These characters were chosen not only because they include some of the important features such as size, form, habit of growth, and productivity, but they are such as may be quickly and accurately measured. The commonly used statistical constants are employed in dealing with all measured characters.

These seven thousand five hundred plants were under experimental control and were handled and grouped so as to give data on four more or less separate and distinct problems which are discussed separately in this paper. They are:

I. The influence of certain chemical injections on variation.

II. Effectiveness of selection in pure lines.

III. Bud variation.

IV. Influence of food supply on variation.

Along with the statistical work mentioned above there were some fifteen thousand plants under careful observation throughout one season for the detection of any plants showing marked deviation (mutation) from the normal fluctuating variability of the species.

It does not seem necessary or advisable, in this paper to take up a discussion of the prevalence of variation, or its importance in

1) Contribution IX. Laboratory of Experimental Plant Breeding, Cornell Univertisy.

Pres nted to the University Faculty of Cornell University for the degree of Doctor of Philosophy.

Induktive Abstammungs- und Vererbungslehre. IV. 
evolution, or the value of the study of variation. Any biological bibliography will list numerous papers on these subjects. Neither is it necessary to defend the use of the statistical method as a biological tool. More and more it is being recognized as the surest means of registering progress in the experimental laboratory.

The plant used, Silene noctiflora, is a wild species of no economic value. It has several qualities which adapt it to a study of this kind; (I) it has not been altered by domestication as have our economic plants; (2) it produces a great abundance of viable seed thus permitting very rapid multiplication of the lines; (3) the seeds are borne in a capsule so that for injection work many seeds may be affected by one injection; (4) after reaching a certain stage of maturity the plants remain for some time unchanged, so that a large number may be measured under very similar conditions. For instance, the height, width, and number of branches remain unchanged and the seed pods persist.

While it would of course be desirable in many ways to use an economic crop in a study of this kind, the requirements of the outlined study made such a choice impossible.

Before discussing the four separate problems mentioned above, we shall consister somewhat in detail the matevials and methods used in the investigation.

\section{Materials and methods.}

Seeds for this study were collected from an isolated plant in the summer of I90\%. This (grandmother) plant was given the pedigree number $25^{\circ}$ and all later pedigree numbers refer back to this plant. In the early spring of Igo8 twentyseven seeds were started in sterilized pots of soil and later transplanted to the "Breeding Garden." The (mother) plants produced were numbered, according to the system outlined in "Plant Breeding“, by Dr. H. J. Webber ${ }^{1}$ ), 250-r, $250-2,250-3, \ldots, 250-27$ and received identical culture and environmental conditions so far as these conditions are under the control of any experimenter.

A number of flower buds on each of these twentyseven plants were covered with paper bags to insure self fertilization. Certain of the buds under bag were then injected with chemicals and rebaged. Others were left untreated to be used as checks and in other ex-

1) Bailey, L. H. Plant Breeding, pp 308-3I9. (Macmillan Co. N. Y. 1906.) 
periments, to be mentioned later. Each single injection was recorded under a given injection number not only to indicate that such a bud had been injected but also to name the chemical employed.

A physician's hypodermic syringe was used to fill the ovary sac with fluid. Most of the buds were treated while very small, certainly before the reduction division had taken place; others only a short time before pollination.

Table I gives the data for the injections made, listing the plant, the injection number, the chemical employed, the strength of the chemical, and the age of the bud at the time of treatment.

Table I.

\begin{tabular}{|c|c|c|c|c|}
\hline $\begin{array}{c}\text { Plant } \\
\text { number }\end{array}$ & $\begin{array}{c}\text { Injection } \\
\text { number }\end{array}$ & Chemical used & Strength of chem. & Age of buds \\
\hline $250-1$ & 579 & $\mathrm{ZnSO}_{4}$ & $1 / 5 \%$ & No color showing \\
\hline$"$ & $5^{8 I}$ & $n$ & $"$ & $"$ \\
\hline$"$ & 585 & $"$ & , & $"$ \\
\hline$"$ & 587 & , & $"$ & $"$ \\
\hline , & 596 & $\mathrm{Ca}\left(\mathrm{NO}_{3}\right)_{2}$ & $1 / 20 \%$ & 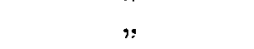 \\
\hline$"$ & 598 & $"$ & $"$ & $"$ \\
\hline$"$ & 600 & $"$ & $"$ & $"$ \\
\hline$"$ & 591 & $\mathrm{H}_{2} \mathrm{O}$ & 一 & $"$ \\
\hline$"$ & 595 & ", & - & $"$ \\
\hline $250-2$ & 610 & $\mathrm{CuSO}_{4}$ & $1 / 10 \%$ & $"$ \\
\hline$"$ & 612 & $"$ & $"$ & $"$ \\
\hline $250-5$ & 615 & $\mathrm{C}_{22} \mathrm{HCl}_{3} \mathrm{O}+\mathrm{H}_{2} \mathrm{O}$ & $"$ &. \\
\hline$\eta$ & 616 & " & $"$ & $"$ \\
\hline$"$ & 617 & , & , & $"$ \\
\hline$"$ & 620 & $"$ & , & $n$ \\
\hline$"$ & 622 & $\mathrm{Z}_{11} \mathrm{SO}_{4}$ & $"$ & $"$ \\
\hline$n$ & 624 & $"$ & $"$ & , \\
\hline $250-6$ & 627 & $"$ & , & 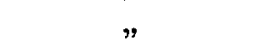 \\
\hline$"$ & 628 & $n$ & 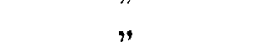 & $"$ \\
\hline $250-7$ & 634 & $\mathrm{Ca}\left(\mathrm{NO}_{3}\right)_{2}$ & $"$ & $"$ \\
\hline$"$ & 635 & $"$ & $"$ & $"$ \\
\hline$"$ & 629 & $"$ & $\Rightarrow$ & " \\
\hline$"$ & 639 & $\mathrm{H}_{2} \mathrm{O}$ & - & , \\
\hline $250-8$ & 644 & $\mathrm{ZnSO}_{4}$ & $1 / 5 \%$ & Buds small \\
\hline , & 649 & $\eta$ & $"$ &, \\
\hline $250-10$ & 663 & $\mathrm{Ca}\left(\mathrm{NO}_{3}\right)_{2}$ & $1 / 10 \%$ & 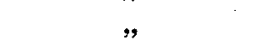 \\
\hline$"$ & 642 & $\mathrm{ZnSO}_{4}$ & $1 / 5 \%$ & $"$ \\
\hline$"$ & 774 & $"$ & $1 / 10 \%$ & Buds very small \\
\hline$"$ & 778 & 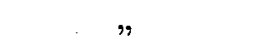 & $"$ & $n$ \\
\hline \multirow[t]{2}{*}{$250-\mathrm{Ir}$} & 769 & $"$ & $1 / 5 \%$ & 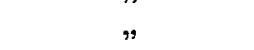 \\
\hline & & & & II* \\
\hline
\end{tabular}


Humbert.

\begin{tabular}{|c|c|c|c|c|}
\hline $\begin{array}{c}\text { Plant } \\
\text { number }\end{array}$ & $\begin{array}{l}\text { Injection } \\
\text { number }\end{array}$ & Chemical used & Strength of chem. & Age of buds \\
\hline $250-11$ & $67 \mathrm{I}$ & $\mathrm{NaCl}$ & $1 / 10 \%$ & Buds very small \\
\hline$"$ & 678 & , & $"$ & $"$ \\
\hline$"$ & 680 & $"$ & " & " \\
\hline$"$ & 707 & $\mathrm{CaCl}_{2}$ & $"$ & Buds opened \\
\hline $250--12$ & 690 & $\mathrm{C}_{2} \mathrm{HCl}_{3} \mathrm{O}+\mathrm{H}_{2} \mathrm{O}$ & $"$ & $"$ \\
\hline$"$ & 692 & " & $"$ & " \\
\hline$"$ & 693 & $"$ & $"$ & $"$ \\
\hline$"$ & 694 &, & $"$ & $"$ \\
\hline , & 706 & $\mathrm{CaCl}_{2}$ & $"$ & Buds small \\
\hline, & 807 & Air & - & Buds very small \\
\hline$n$ & 809 & $"$ & - & $"$ \\
\hline$\because$ & 810 & $"$ & - &, \\
\hline$"$ & 812 & $"$ & - & , \\
\hline $250-13$ & 710 & $\mathrm{MgSO}_{4}$ & $1 / 10 \%$ & $"$ \\
\hline, & $7 \mathrm{II}$ & $"$ & $"$ & 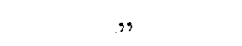 \\
\hline$"$ & 712 & $"$ & $"$ & " \\
\hline$"$ & 714 & $\because$ & ", & $"$ \\
\hline$"$ & 715 & $"$ & $"$ & , \\
\hline , & 717 & $"$ &, & " \\
\hline$"$ & 719 & $\mathrm{NaCl}$ & $1 / 20 \%$ & , \\
\hline$"$ & $7^{21}$ & $"$ & $"$ & $"$ \\
\hline$"$ & 724 & $"$ & $"$ & $"$ \\
\hline$"$ & 725 & $"$ & $"$ & , \\
\hline$"$ & 735 & $\mathrm{FeSO}_{4}$ & $"$ & $"$ \\
\hline$"$ & $73^{6}$ & $"$ & $"$ & $"$ \\
\hline$"$ & 737 & , & , & , \\
\hline$"$ & 738 & $"$ & $"$ & $"$ \\
\hline " & 739 & $"$ & $"$ & $"$ \\
\hline$"$ & $74^{\circ}$ & $"$ & $"$ & $"$ \\
\hline$"$ & 742 & $"$ & $"$ & $"$ \\
\hline $250-14$ & 726 & $\mathrm{ZnSO}_{4}$ & $"$ & , \\
\hline$"$ & 727 & $"$ & $"$ &, \\
\hline$"$ & 728 & $"$ & $"$ & , \\
\hline$"$ & 729 & $"$ & $"$ & $"$ \\
\hline$"$ & 730 & $"$ & $"$ & $"$ \\
\hline$"$ & $73 \mathrm{I}$ & " & $"$ & $"$ \\
\hline " & 745 & $\mathrm{Ca}\left(\mathrm{NO}_{3}\right)_{2}$ & $"$ & $"$ \\
\hline$"$ & 747 & $"$ & $"$ & $"$ \\
\hline$"$ & 749 & $"$ & $"$ & $"$ \\
\hline , & $75 \mathrm{I}$ & ", & $"$ & $"$ \\
\hline$"$ & 753 & $\mathrm{C}_{2} \mathrm{HCl}_{3} \mathrm{O}+\mathrm{H}_{2} \mathrm{O}$ & $1 / 10 \%$ &. \\
\hline$"$ & 754 & $"$ & $"$ & $"$ \\
\hline
\end{tabular}


The table given represents only those treatments which were successful. If all of the buds treated had developed seeds, then plants 250-I to $250-\mathrm{I}_{4}$ inclusive would have been almost equally represented in the table. Treated buds on plants $250-3,250-4$, and $250-9$ dropped off soon after being injected. Plants $250-\mathbf{r} 3$, and 250-I4 were very susceptable to treatment. Since all plants were worked with equal care we have an indication of great variability in the resistance of plants to the injection treatment.

Table 2 gives the data taken on the 1908 (mother) plants as regards height of plant, width of plant, number of branches per plant, and number of seed pods per plant. Measurement for width was taken on but four plants. The figures for height and width represent so many centimeters.

Table 2.

\begin{tabular}{|c|c|c|c|c|}
\hline Plan & Height & Width & Branches & Seed pods \\
\hline $250-1$ & 62.3 & - & 27 & 448 \\
\hline,$\quad 2$ & 60.5 & - & 25 & 451 \\
\hline$" 3$ & 40.5 & - & I I & 305 \\
\hline$" 4$ & 77.0 & - & I9 & 577 \\
\hline$" \quad 5$ & 64.5 & - & 23 & 488 \\
\hline$" \quad 6$ & 69.5 & - & 23 & 512 \\
\hline$\eta$ & 70.0 & - & 25 & 505 \\
\hline$"$ & 69.0 & - & 26 & 547 \\
\hline " & 7 I.O & - & 26 & 563 \\
\hline , IC & 72.5 & -- & 23 & 547 \\
\hline "II & 77.0 & - & $2 I$ & 472 \\
\hline "I2 & 80.0 & 46.5 & 26 & 695 \\
\hline$" 13$ & 70.5 & 44.0 & 24 & 747 \\
\hline$\Rightarrow \quad \mathbf{I}$ & 70.3 & - & 22 & 603 \\
\hline , I & 68.5 & - & 26 & 523 \\
\hline$\Rightarrow \quad$ It & 52.0 & 26.0 & 9 & 287 \\
\hline$" 17$ & 74.0 & - & 24 & 693 \\
\hline$\Rightarrow \quad x$ & 64.0 & - & 24 & 486 \\
\hline$\Rightarrow 15$ & 69.3 & - & 14 & 485 \\
\hline$\Rightarrow 20$ & 68.5 & 36.0 & 22 & 395 \\
\hline, 21 & 72.0 & - & 21 & 680 \\
\hline$\Rightarrow 2$ & 68.5 & - & 23 & 545 \\
\hline " 23 & 66.0 & - & 24 & 576 \\
\hline$" 24$ & 71.0 & 一 & 27 & 573 \\
\hline$" 25$ & 68.0 & - & 22 & 671 \\
\hline, 26 & $67 \cdot 5$ & - & 25 & 475 \\
\hline$\Rightarrow 27$ & 72.5 & - & 26 & 663 \\
\hline
\end{tabular}


In the early spring of Igog seeds were started in the green house in sterilized soil as follows: (I) all the seeds from injected capsules, planting the seeds from each capsule in a separate flat; (2) seeds from six capsules each from plants $250-$ II, 250-I2, and 250-I3, planting the seeds from each capsule in a separate flat. These six capsules were from different parts of the mother plant and all under bag. (3) seed from bagged capsules from plants $250-\mathrm{x}, 250-2$, $250-5,250-6,250-7,250-8,250--10,250-\mathrm{II}, 250-\mathrm{I} 2,250-\mathrm{I} 3$, $250-14,250-16$, and $250-20$. In this latter case the seeds came from separate capsules on each plant and these were mixed together. The seeds from each plant were planted in a separate flat. As soon as weather conditions would permit the young plants from the injected capsules and the mixed seed from individual mother plants 250-I, 250-2, etc., were taken to the plant breeding garden and set out in rows on a very uniform plot of ground. The young plants were one foot apart in the row and the rows were three feet apart. Very few died and the plot received thorough cultivation so that the plants of the 1909 crop had uniform environmental conditions to a remarkable degree. The progeny from separate capsules of mother plants 250-II, 250-I2 and 250-I3 were similarly transplanted on another plot of ground known as the "Mitchell Farm" and equally well taken care of. It does not seem necessary to give a map of the plantings. It might be well, however, to restate the system of pedigree numbers used with special reference to the Igog (third generation) crop, since from this crop most of the data are taken. The lines from injected capsules were all planted in the plant breeding garden. Each line is numbered to represent the grandmother plant, the mother plant, and the injection number. For example, $250-\operatorname{IIC} 67 \mathrm{I}$ shows the line to have come from grandmother plant 250 , from mother plant $250-I I$, and from a single capsule injected with chemical number $67 \mathrm{I}$. By turning to the table of injections we see that the chemical used $(67 \mathrm{I})$ was $\mathrm{NaCl}$, that it was of $1 / 10 \%$ strength, and that the bud was very small when treated. Individual plants of this line would have one additional figure added to the pedigree number thus: $250-$ IIC 67 I-I or $250-$ IIC 67 I-I3 etc., according to the position of the plant in the row.

The lines from capsules not injected from mother plants $250-x$, $250-2$, etc., were all planted in the plant breeding garden and are numbered $250-$ Ia, $250-2 a$, etc. Individual plants receive one additional figure thus: $250-$ ra--I etc. 
The lines from separate capsules of mother plants 250-II, 250-I2, and 250-I3 were all planted on the Mitchell Farm and are numbered 250-IIU, 250-IIV, 250-IIW, 250-IIX, 250-IIY, $250-I I Z, 250-I 2 U$, etc.

Table 3 shows the great difference in the soil conditions that existed between the Plant breeding garden and the Mitchell Farm.

Table 3 .

\begin{tabular}{|c|c|c|}
\hline & P. B. Garden & Mitchell Farm \\
\hline $\mathrm{K}_{2} \mathrm{O} \ldots \ldots \ldots$ & $0.46 \%$ & $0.43 \%$ \\
\hline$\cdots \cdots \cdots \cdot \ldots \cdot \cdots$ & $0.28 \%$ & $0.31 \%$ \\
\hline ................ & $0.25 \%$ & $0.13 \%$ \\
\hline$\cdots \cdots \cdot \cdots$ & $9.35 \%$ & $5.56 \%$ \\
\hline Acidity . . . . . . . . . . . & $17.00 \%$ & I $5.00 \%$ \\
\hline Moisture content. . . . . . . . . . & $\mathbf{1} .89 \%$ & $1.00 \%$ \\
\hline
\end{tabular}

All plants were under careful and continuous observation throughout the summer and notes were taken relative to marked deviation of particular plants from the average of the line.

When the plants were mature all of the individuals in sixtythree chosen lines were measured for height of plant, width of plant, number of branches per plant, and number of seed pods per plant. All measurements were taken in centimeters.

In making the arrays for the character "Number of seed pods", the seed pods were grouped in bunches of ten. For example, class 210-230 is treated as though but three individuals were concerned; that is, 210, 220, and 230. The mean of the class would thus be taken to be 220. This arbitrary grouping was done to save time in working out the arrays and constants. It affects all constants somewhat, hence this explanation.

The constants were worked out after the method given in Davenport's „Principles of Breeding“" ${ }^{1}$ ). All computations were carried out three decimal places. Where the fourth decimal was 6 or larger I was added to the third decimal. Where the fourth decimal was 5 or less it was dropped.

Below are given the frequency distribution of all the plants measured for each of the different characters (tables 4 to 7 inclusive), and the constants for each "population" (tables 8 to II inclusive).

1) Davenport, E. Principles of Breeding, Appendix. (Ginn and Co. Chicago and Boston. 1907.) 


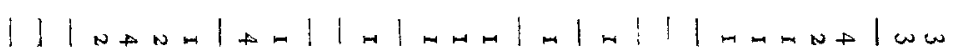

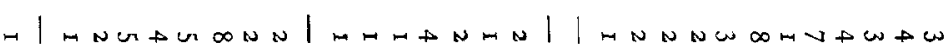

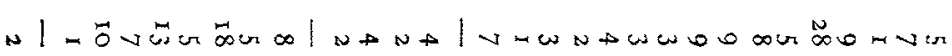
NN| VजU

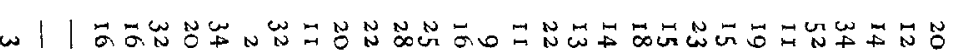

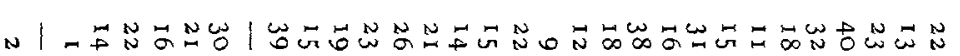
|

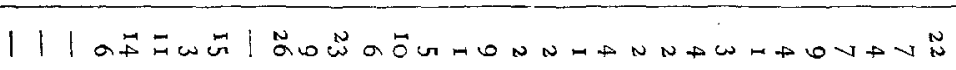

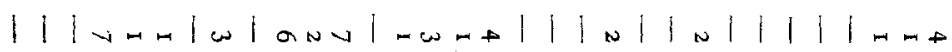
$75-77$

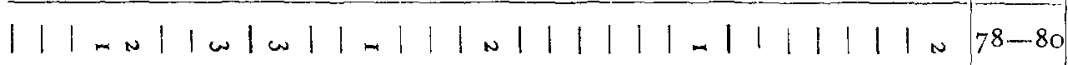

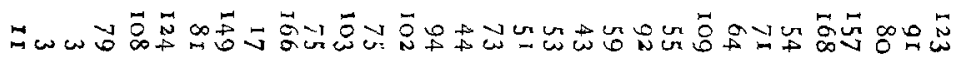




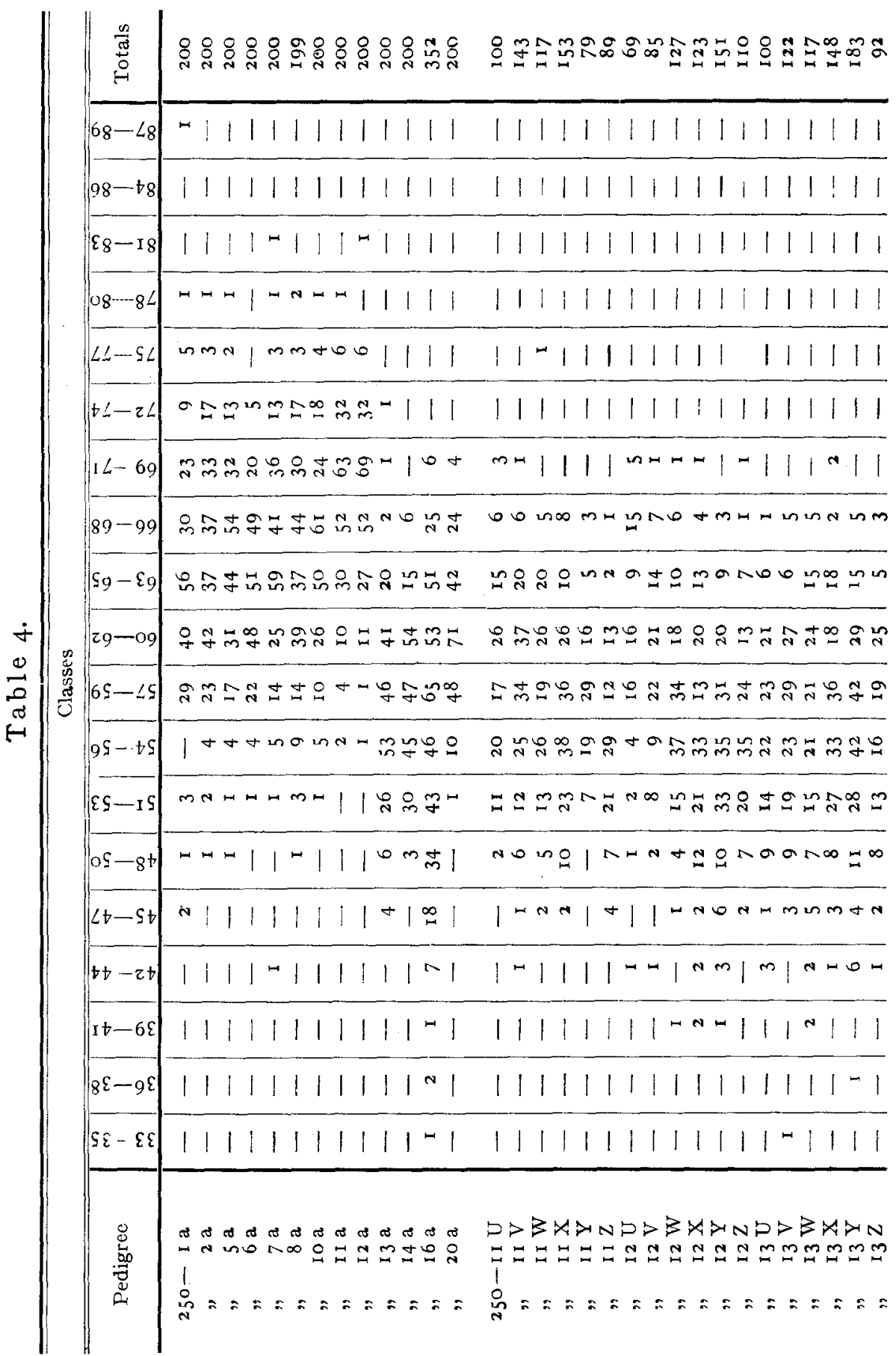




\begin{tabular}{|c|c|}
\hline 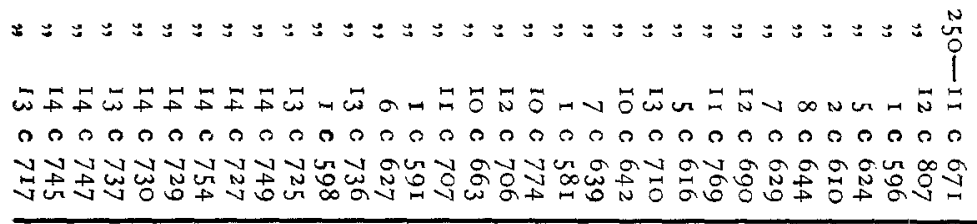 & 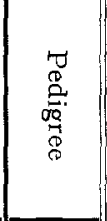 \\
\hline $1111-111111111111111111111111111$ & $(2-14)$ \\
\hline 11111111111111111111111111111111 & $|15-17|$ \\
\hline$|-1| 1-1|1| 1|1| 1|1| 11111111111111$ & $|18-20|$ \\
\hline$|1|||-|1-1|-|-m| 1|-N| 1|1| 1|1-1| 1$ & $\mid 2[-23||$ \\
\hline||$|-m M-|||-||-m-|||\omega||N N m| \omega \rightarrow m+1$ & $24-26$ \\
\hline 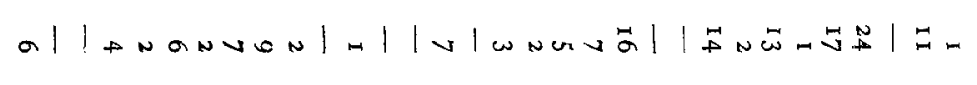 & $27-29 \mid$ \\
\hline 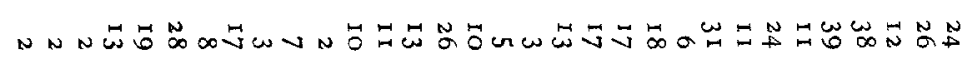 & $30-32$ \\
\hline 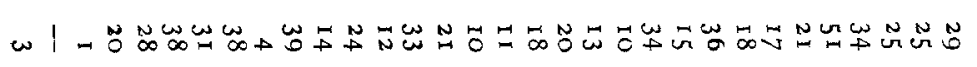 & $33-35$ \\
\hline 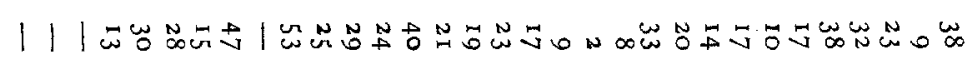 & $36-38$ \\
\hline 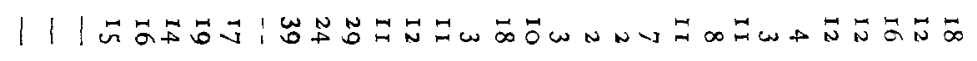 & $39-4 I$ \\
\hline$|1|$ O0 OUF & $42-44 \mid$ \\
\hline $\mid$ | & $45-47$ \\
\hline 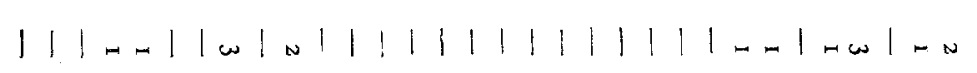 & $48-50$ \\
\hline 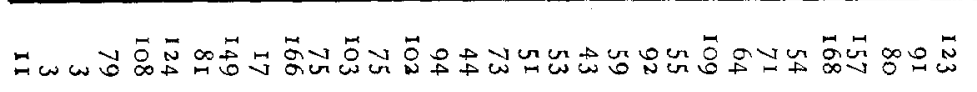 & $\frac{\overrightarrow{0}}{\rho_{0}^{3}}$ \\
\hline
\end{tabular}


A quantitative Study of Variation, Natural and Induced, etc.

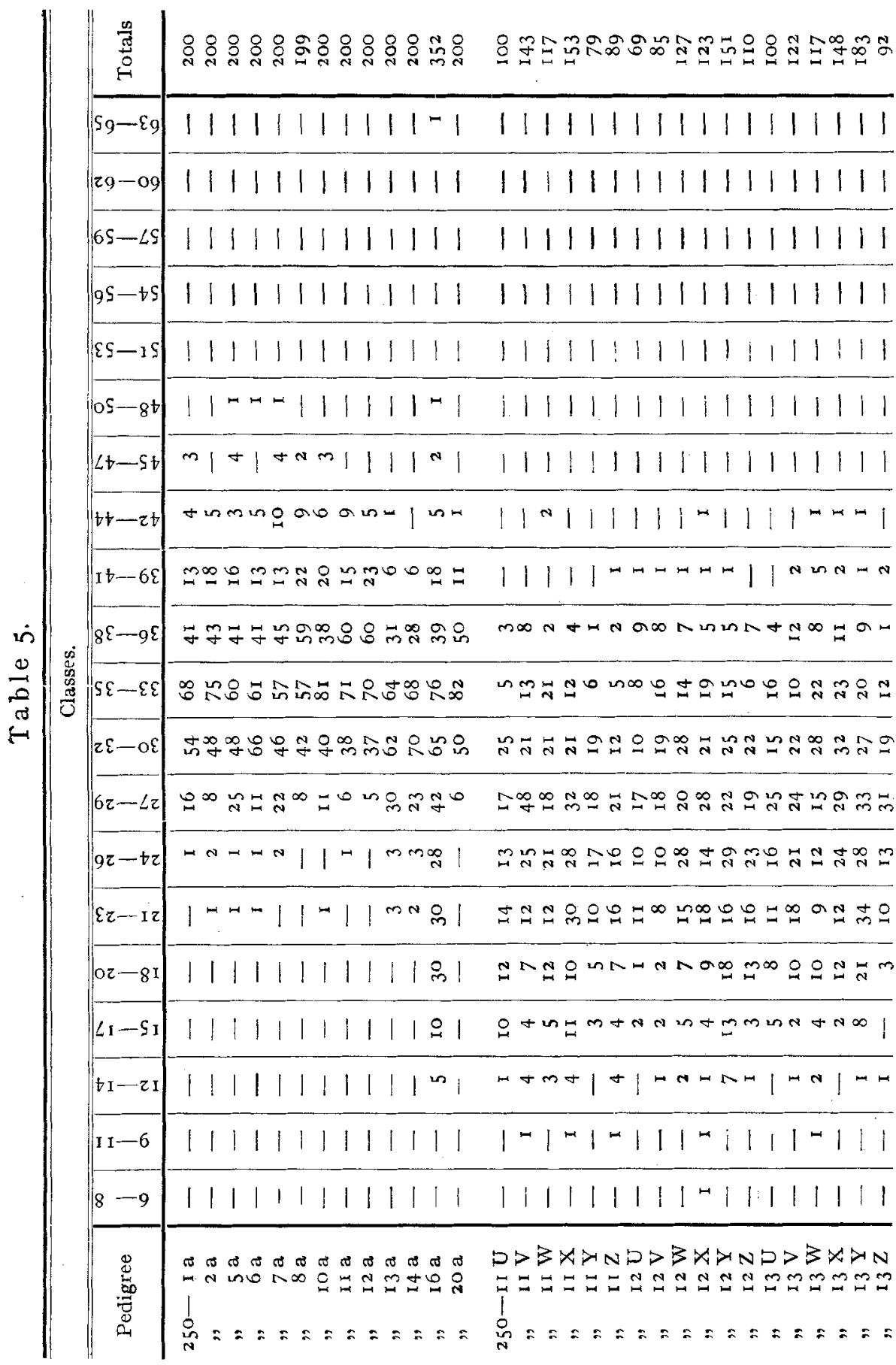


||||$|-| \omega n|| n|\omega| \omega-V \mid \omega \omega \rightarrow n \rightarrow-M N M N \omega$

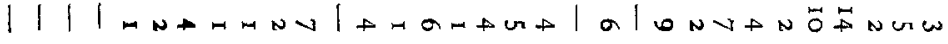

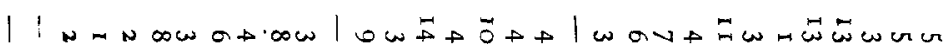

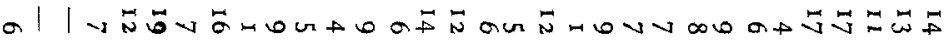

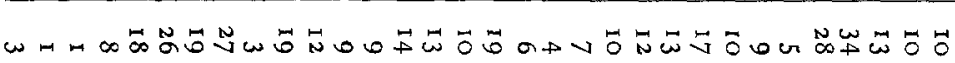
H| |

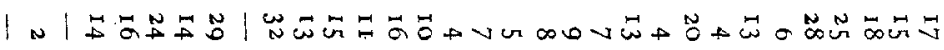

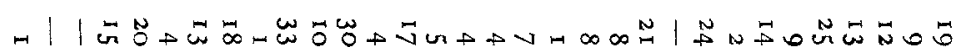

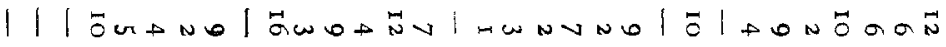

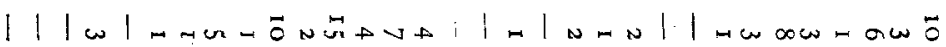

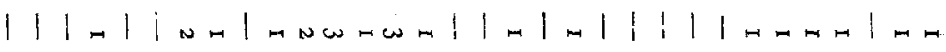
$|1| 1|1| 1|m|-1|1| 1|1-1| 1|1| 1|1| 1 \mid$ $11|1| 1|1|-1|1| 1|1| 1|1| 1|1| s|1| 11$ $111111111111111111111111111 m 1111$ $1|1| 1 \mid 11-11-111111111111111111$

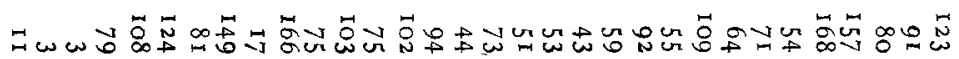


A quantitative Study of Variation, Natural and Induced, etc.

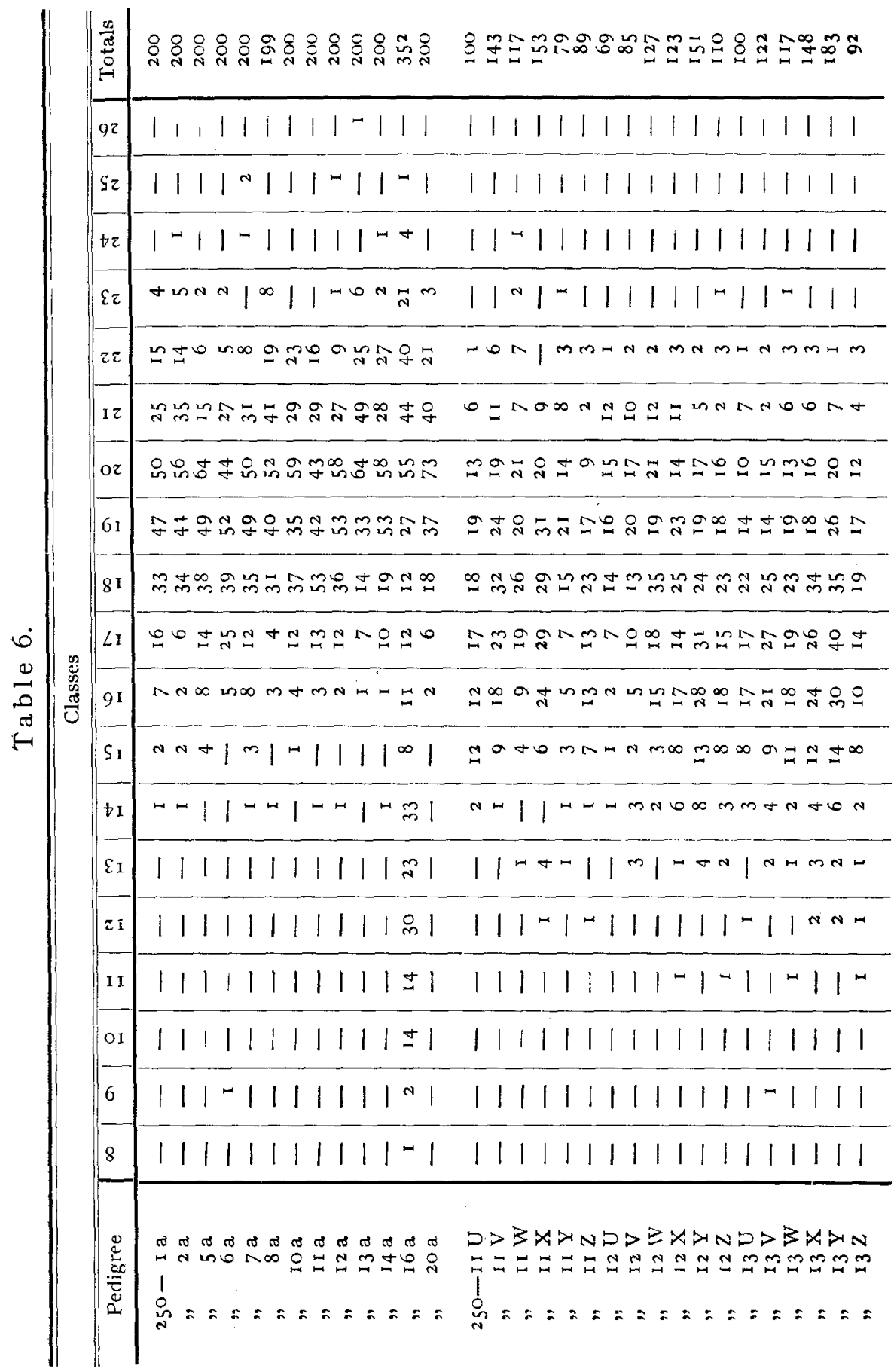




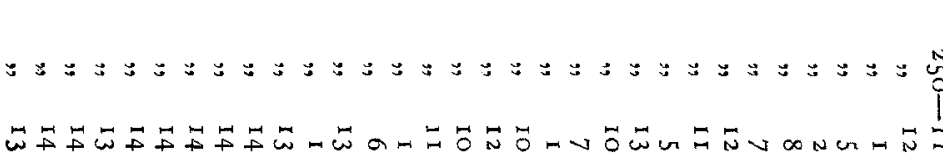
- 0000000000000000000000000000000

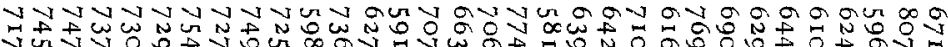

تسพ 
A quantitative Study of Variation, Natural and Induced, etc.

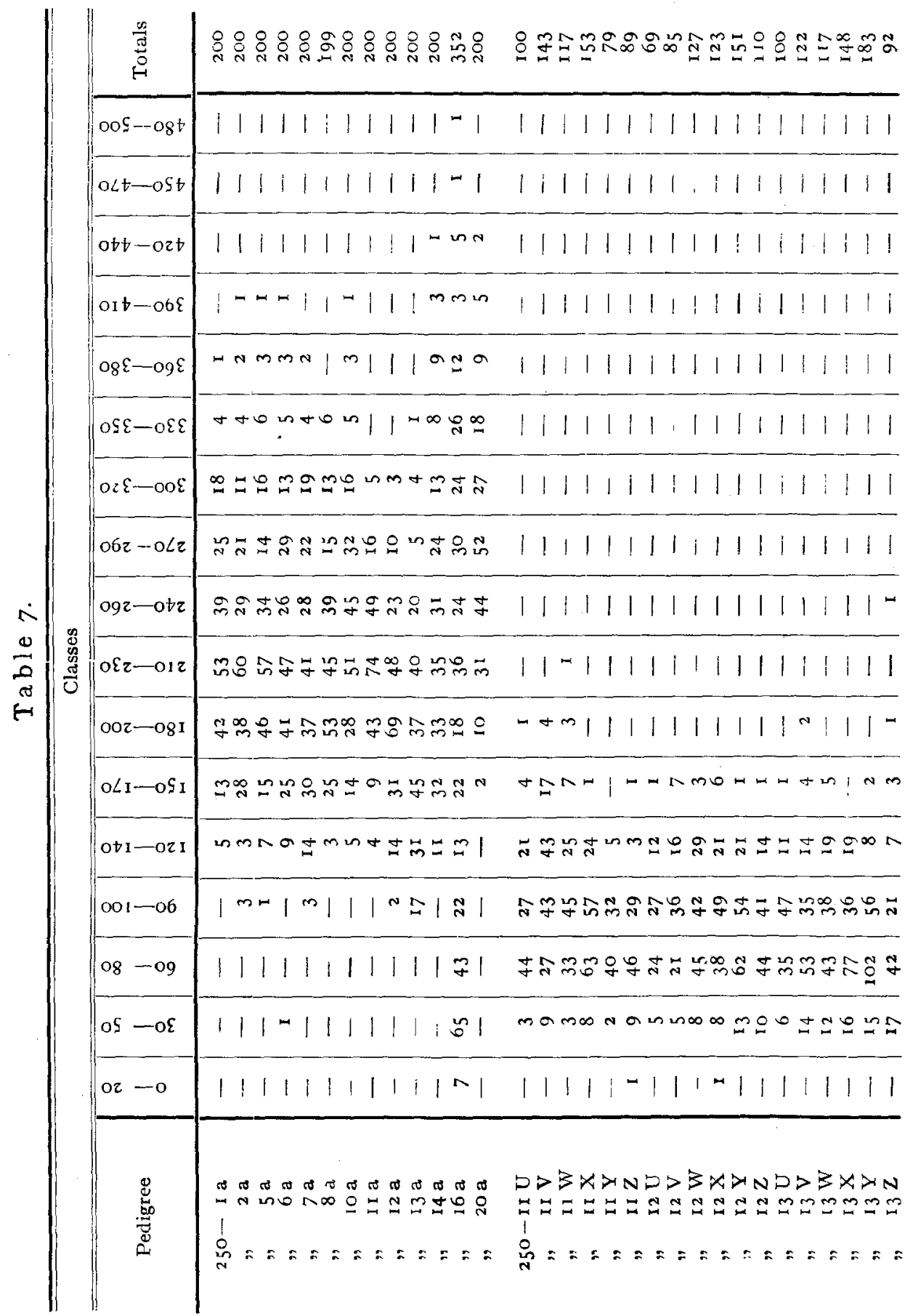


Table 8 gives the constants for all lines (or populations) for the character "height".

Table 8 (contd).

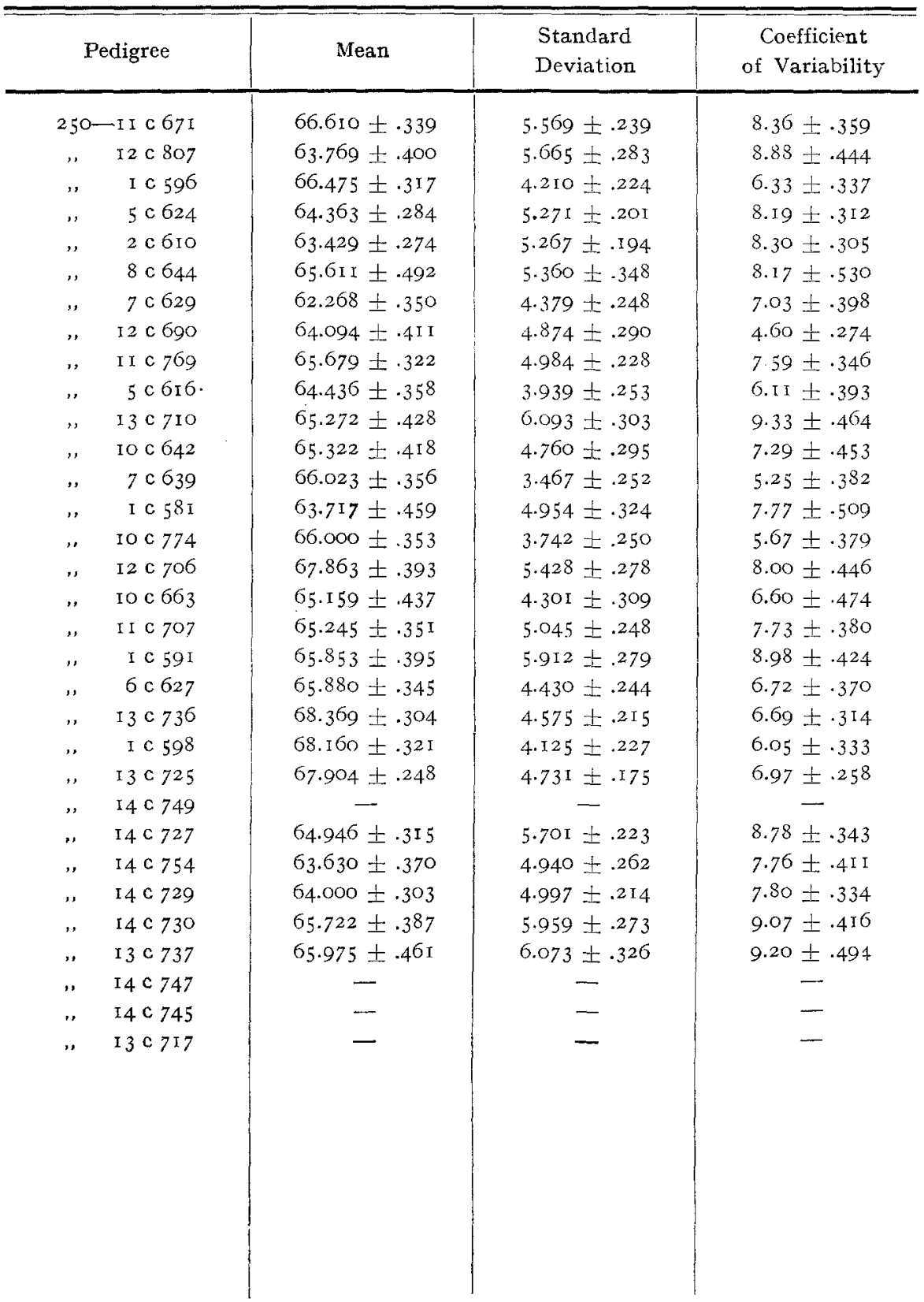


Table 8.

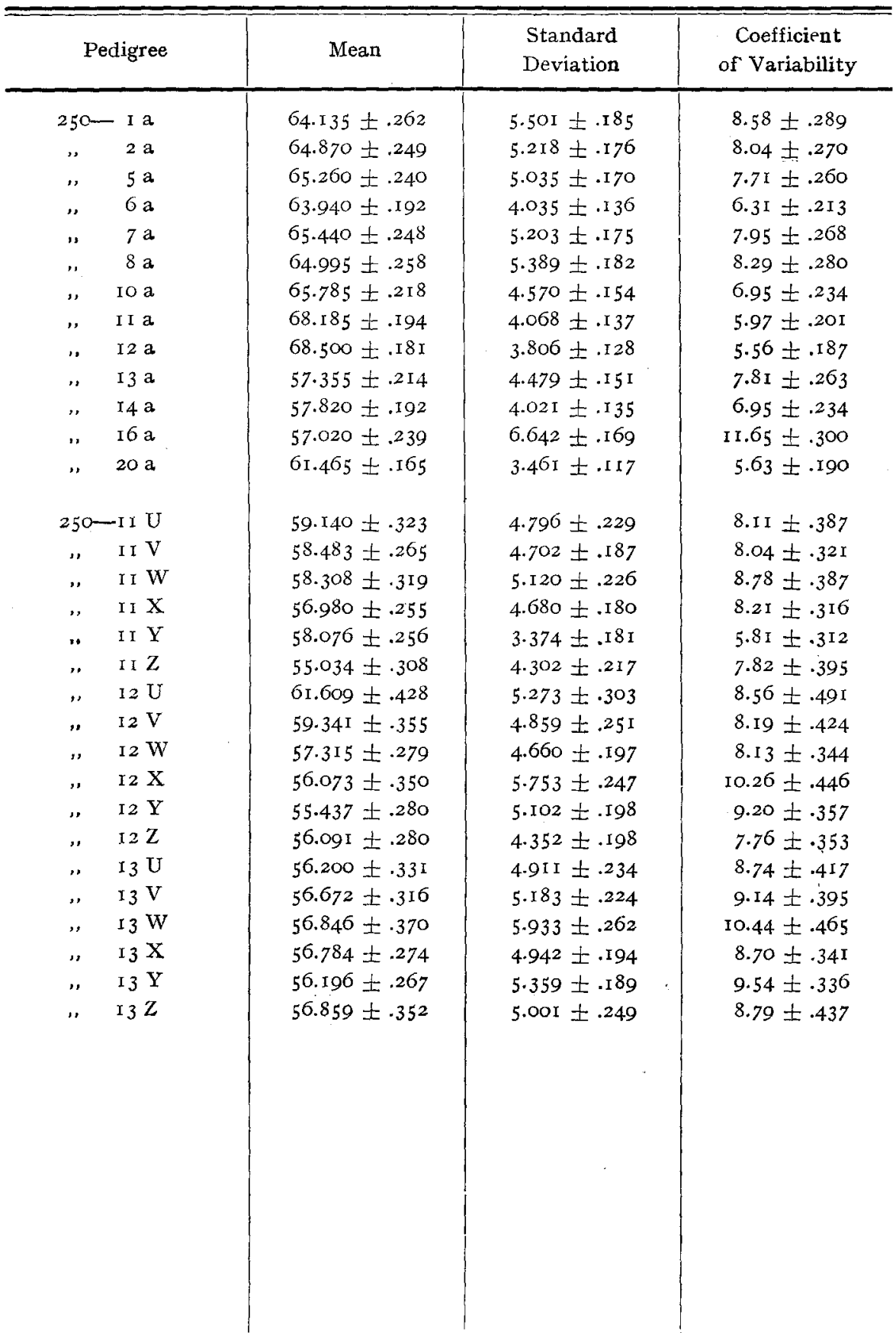


Table 9 gives the constants for all lines for the character "width".

Table 9 (contd).

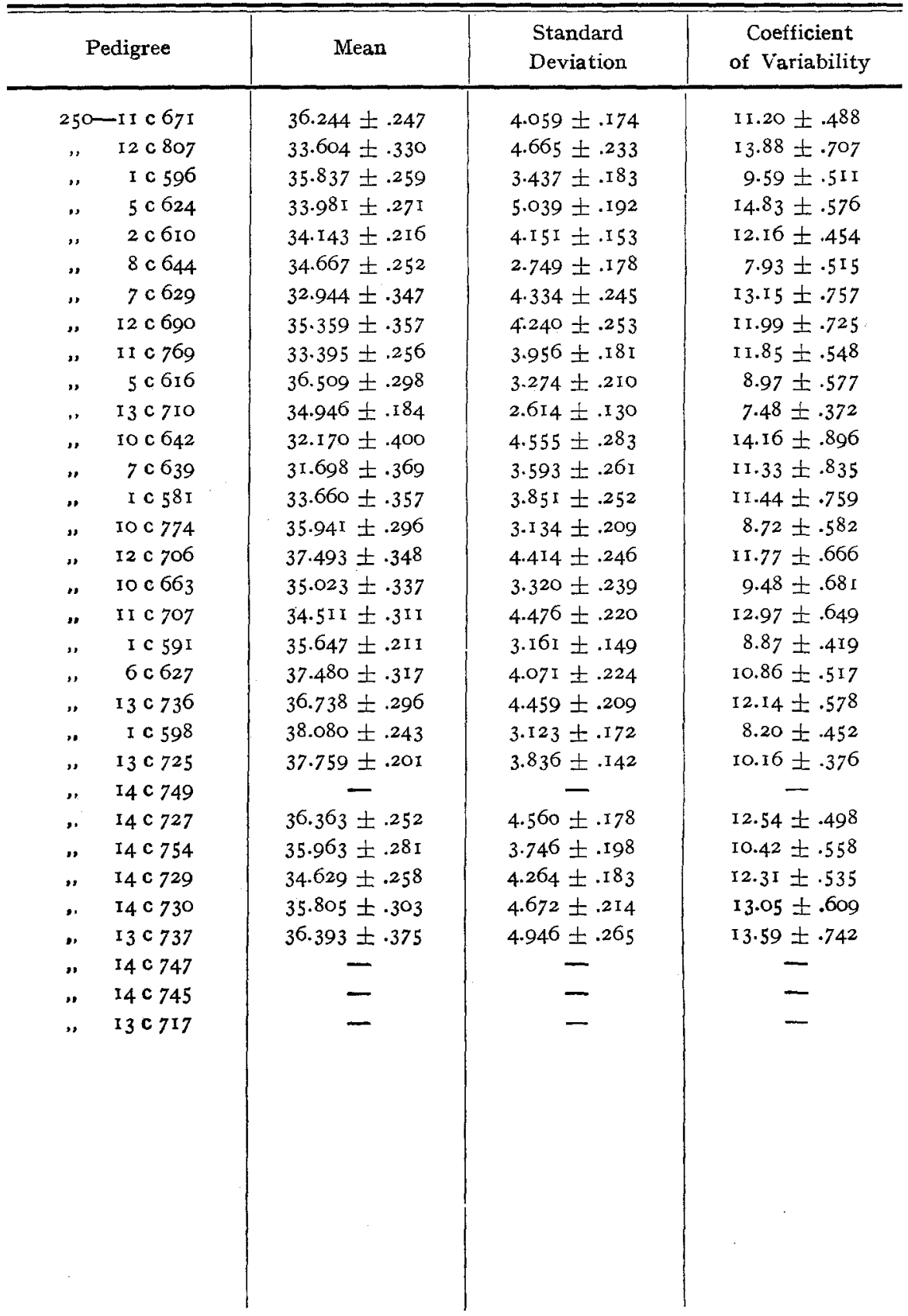


Table 9.

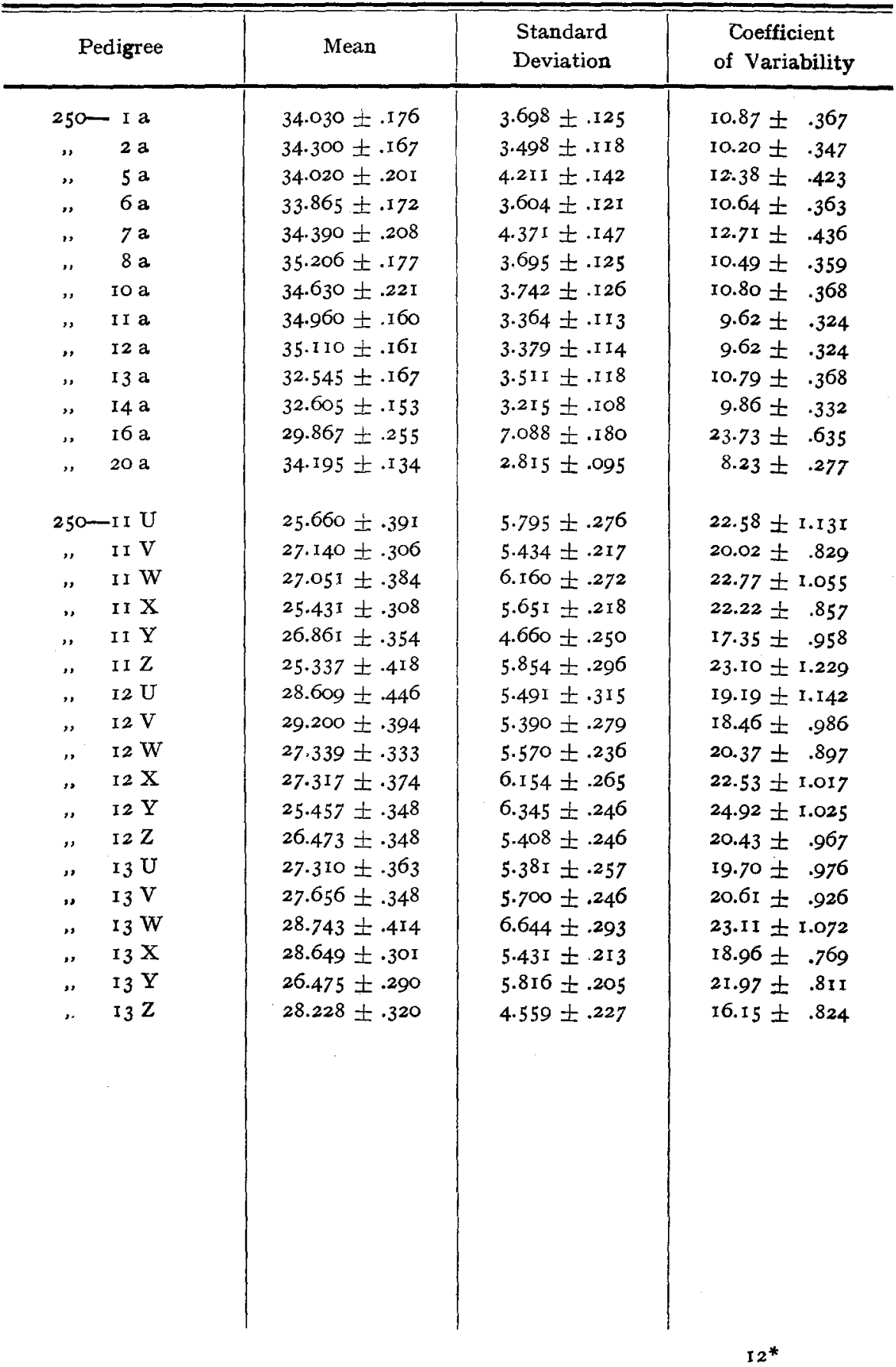


Table Io gives the constants for all lines for the character "number of branches".

Table Io (contd).

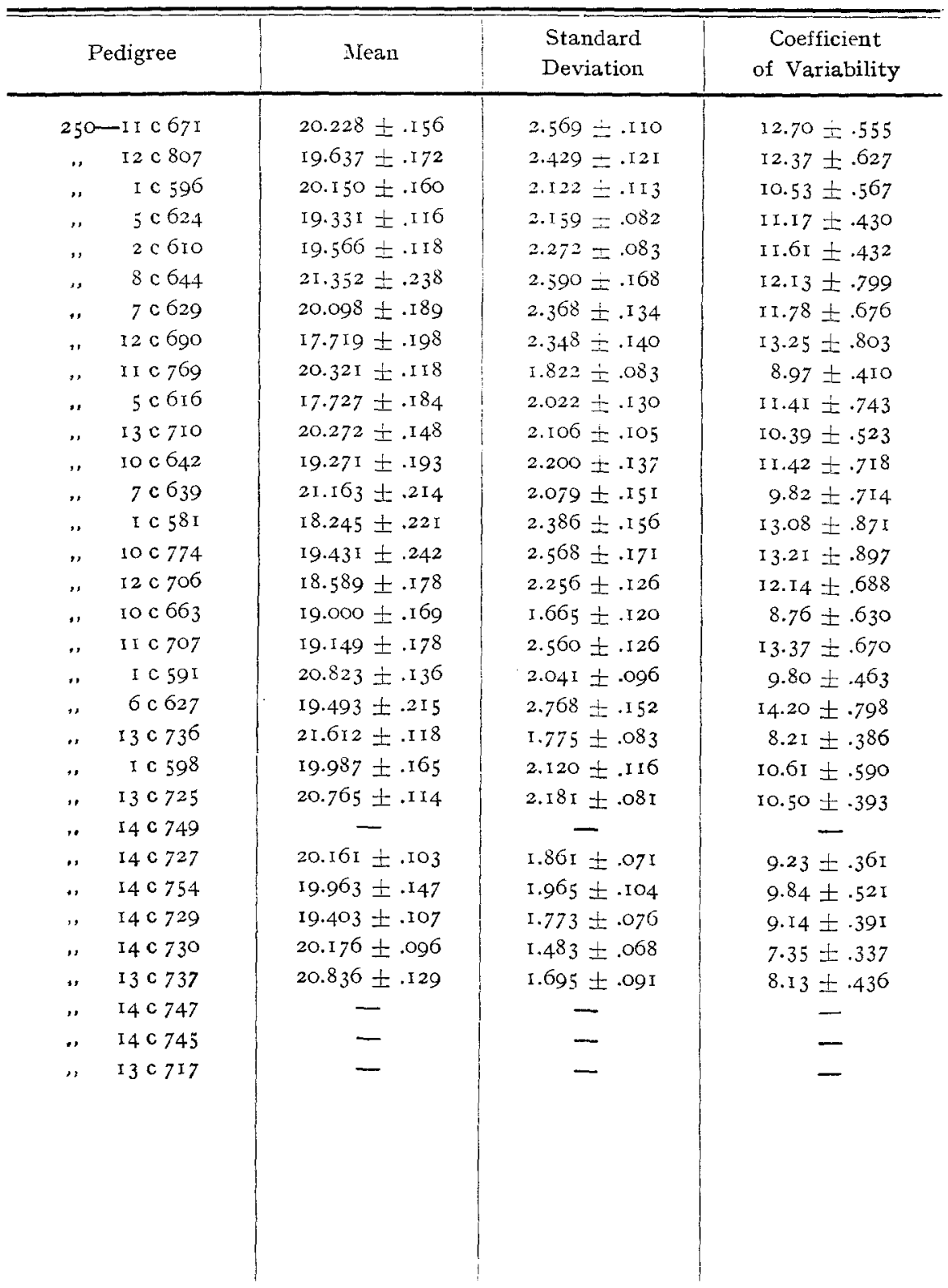


Table ro.

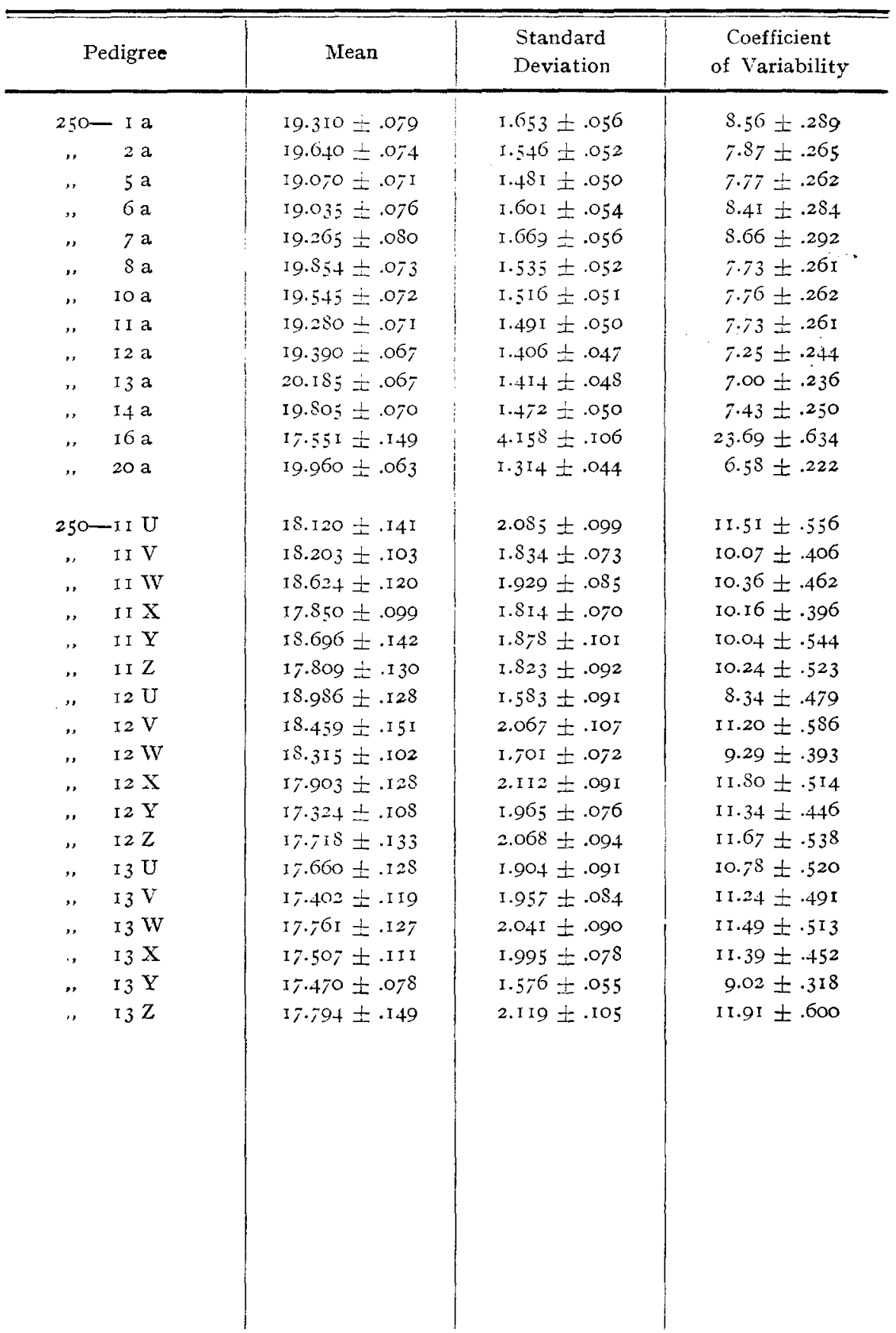


Table II gives the constants for all lines for the character "number of seed pods".

Table II (contd).

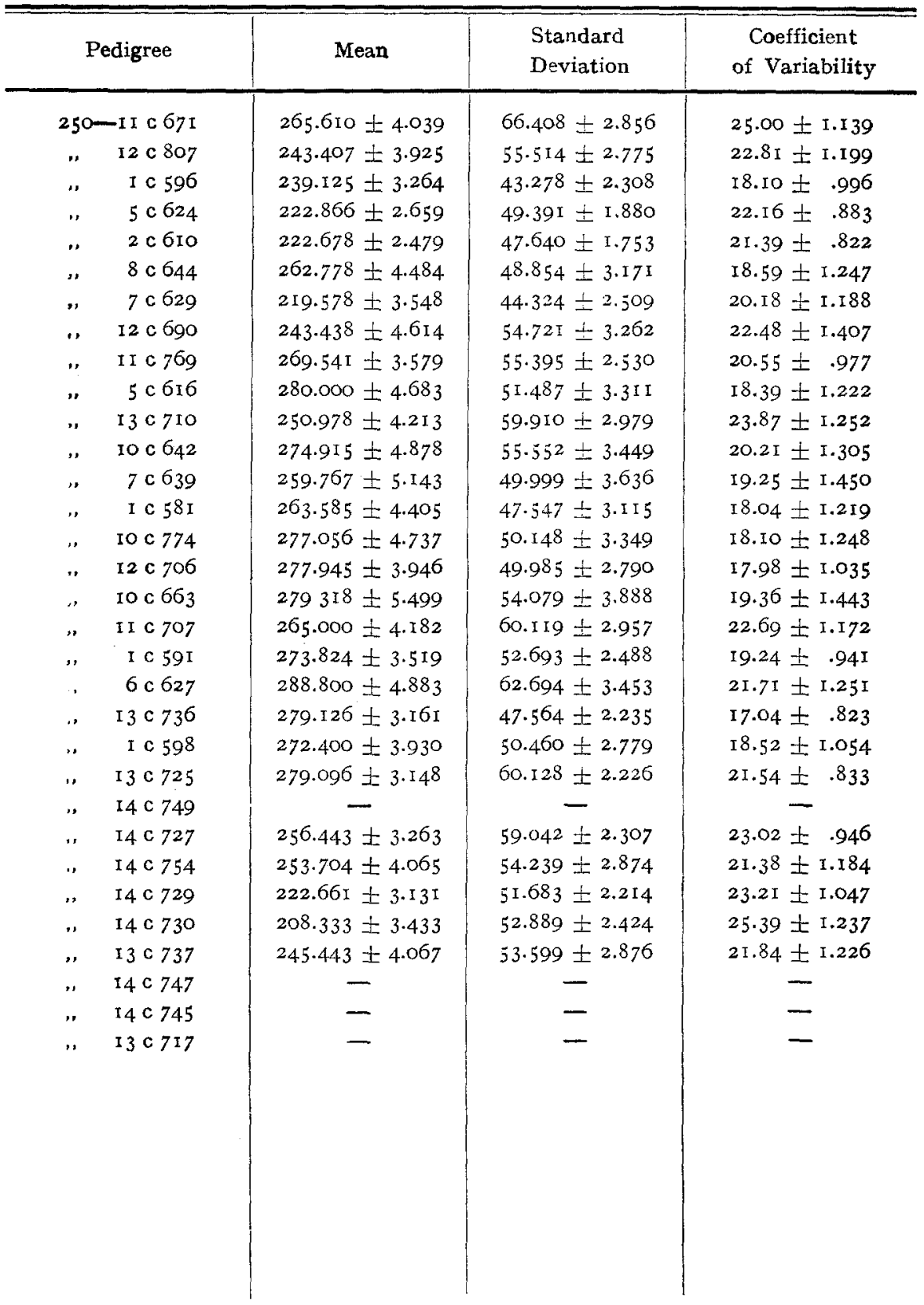


Table II.

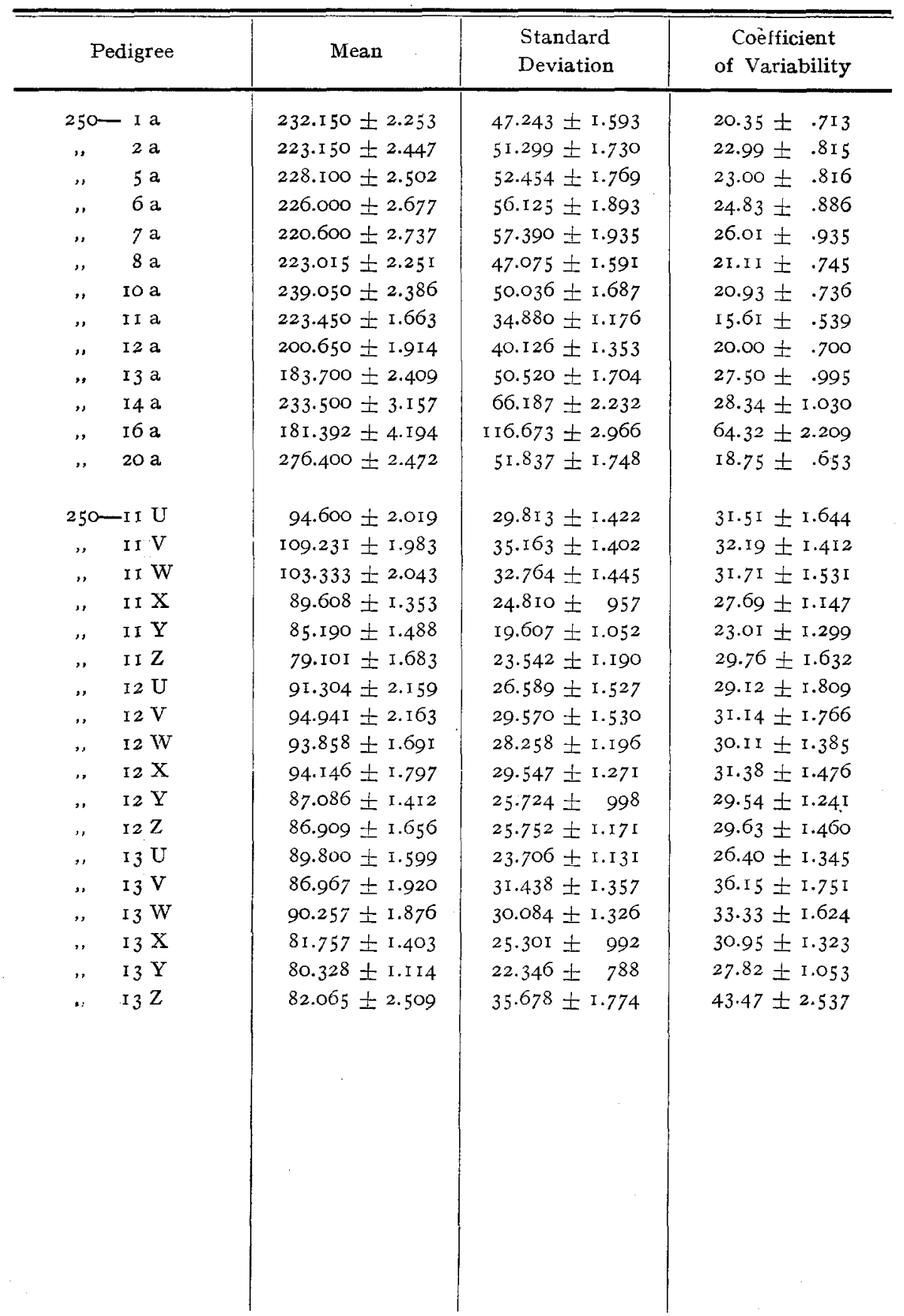




\section{Influence of Certain Chemical Injections on Variation.}

The experiment which forms the subject matter of Chapter I of this paper was planned to give data on the influence which certain chemical injections may have upon the amount and range of variation in plants, when such chemicals are injected into the young developing ovaries. The experiment was suggested by the work of Dr. D. T. MacDougal ${ }^{1}$ ) of the Carnegie Institution. MacDougal wished not only to produce mutations by artificial means but also to study the problem of "localization of the mutations in the life history of the plant". He wished to determine the exact stage at which the mutations take place so that the chromosomes might be examined with a view to determining what changes occur in them in connection with saltations in inheritance. $\mathrm{He}$ considered it most probable that changes which constitute mutations would take place prior to the reduction divisions in the embryosac or in the pollen mother cell, and therefor made the injections before fertilization had taken place. He divided the chemicals used into two classes: those of high osmotic value and those stimulative in low concentrations. The experiments on Begonia rotundifolia, with a species of Cleome, and Abutilon abutilon were without success so far as the production of new types was concerned. Some pedigreed strains of Oenothera lanarckiana were then treated with copper sulfate one part to four hundred thousand parts $(1 / 400000)$ immediately previous to pollination, and the resultant seeds planted in Sept. I905. A study of the plants showed the usual mutations of the species in about the normal proportions. $O$. biennis was next employed. In this species magnesium sulfate seemed to be without effect, but where zinc sulfate $1 / 500$ was used one rosette was discovered which differed greatly from any known form, some of the differences being plainly apparent even in the earliest leaves of the seedling. The parental form had been under careful observation for five years and no plant like the aberrant form under consideration had been noted. The plant was plainly a mutation, and supposedly one caused by the zinc solution which had been injected into the ovary of the mother plant.

1) NacDouga 1, D. T. Discontinuous Variation in Pedigree Cultures. Pop. Sci. Mo. 69: 207-225. I906.

- - Induction of Mutations. Carnegie Pub. 81: 61-64. 1907.

- Heredity and Environic Forces. Science N. S. 27: I21-128. Jan. 24, 1908.

- The Direct Influence of Environment. Fifty Years of Darwinism. pp. I14 -I 42. 09 . 
The mutant produced seeds in 1905 which when planted reproduced the characters of the parent within the limits of fluctuating variability. In succeeding crops the plants breed true even when growing uncovered with branches interlocking with $O$. biennis. Either the two types do not cross or the derivative is dominant.

Dr. MacDougal also used an evening primrose from Patagonia, Raimannia odorata, with decisive results. Identical mutations were produced by several different means: two mutations from an ovary treated with a ten per cent solution of sugar, ten from an ovary treated with calcium nitrate $1 / 1000$, and one from an ovary that had been subjected to the influence of the radium pencil. These mutations could be easily detected as soon as the cotyledons had become fully expanded. The following changes were noted. The leaves of the parental form were villous hairy, those of the mutant were entirely glabrous. The blades of the parental form become fluted, while those of the mutant receive the extra growth in the midrib and the margins become resolute. The leaves of the mutant are narrower than those of the parental form, and whereas the parental form is of biennial habit the mutant is inclined to be perennial. These characters were irreversible and fully transmissible in successive generations. The following year capsules treated with zinc sulfate $1 / 2000$ produced the same mutant, as did distilled water (subject ofcourse to the impurities of the still).

MacDougal next made injections on several species growing naturally in the vicinity of the desert laboratory of the Carnegie Institution. These species included Cereus, Ilentzclia, Argemone, Nicotinia, Escholtzia, Penstemon. and nine species of the Gencra Opuntia, and the chemicals used included calcium nitrate, potassium iodide, zinc sulfate, and methyl-blue in various proportions from $1 / 250$ to $1 / 50000$. Many plants, presumably from many or all of these treatments were under observation at the time of the last report. Decisive results with Penstemon Wrightii are reported. Of eighty plants from injected ovaries of Penstemon sixty bloomed, of which twenty were distinctly different from the parental form and in these twenty were eight distinct types. Several different injections were concerned in the production of these eight new types. "The revolution of the corolla segments, the absence of the stiff clump of trichomes from the lower lip, increase in viscidity, mottling of the flower, and adhesion of leaf bases resulting in prefoliation, are some of the distinguishing characteristics of the new forms." Of these characters, 
some are already displayed by members of the Genus, while some of the progressive and retrogressive changes seem to be taken before any relative had moved in the same direction.

Mention was made of the fact that methyl-blue was used as one of the injection chemicals. This was done for the purpose of studying the mechanics concerned in the changes which injections may cause. It was found that the dye is taken up not only by the tissues of the ovary but that the pollen tube before it reaches the ovary also takes up a considerable amount. It is of course to be inferred that the other injections were taken up to a similar degree. The generative nucleus must therefore pass through tissue that is impregnated with a foreign substance before it becomes effective in the ovary. Changes (mutations) therefor may be caused by the influence of the chemical on the ovules, or on the sperm or both and the change may be before or after the reduction divisions of the embryo-sac. The changes may be due to the stimulative effect of the solution used or perhaps it may be that a direct disturbance of the chemical balance of the chromatin and plasma is effected.

The work of Dr. MacDougal is the only bit of research found which bears directly on the problem named in the title of this chapter. Because of this it is given somewhat in detail. In all injection work of this nature an attempt is made to affect the germ-plasm of the plant directly instead of working on the somatic tissues of the plant as so many experiments on "influence of environment" and "inheritance of acquired characters do". There are however several pieces of research which attempt to produce mutations by artificial means so closely related to the injection work that they should receive brief mention here. Such papers include those of Tower ${ }^{1}$ ), Blaringham ${ }^{2}$ ), Gager ${ }^{3}$ ), Knox ${ }^{4}$ ) and Klebs ${ }^{5}$ ). The two latter are somewhat from the standpoint of "inheritance of acquired characters".

Prof. Tower has worked for more than twelve years on beetles of the genus Leptinotarsa, subjecting them to various combinations of

1) Tower, W. L. An Investigation in Evolution in Chrysomelid Beetles of the Genus Leptinotarsa. Carnegie Pub. 48. 1906.

\#) Blaringham, L. Mutation et Traumatismes. 248 pp. 1908.

$\left.{ }^{3}\right)$ Gager, C. S. Effects of the Rays of Radium on Plants. Mem. N. Y. Bot. Gar. Vol. IV. Ig08.

4) Knox, Alice A. Induction, Development, and Heritability of Fasciations. Carnegie Pub. 98: I-20. 08 .

5) Klebs, Georg. Uber die Nachkommen künstlich veränderter Blüten von Sempervivun. Sitzungsber. d. Heidelberger Akad. d. Wiss. I909. 
heat, moisture etc. Pedigreed cultures have been used and important experiments repeated several times so that the data collected are of great value. A few quotations will serve to give some idea of the work and the success attained measured in terms of new forms produced. "The use of moisture and temperature in unusual degrees of intensity has given rise to a number of modified forms and characters. From a normal form of $L$. undecimlineata a race was derived which resembles Jocoby's L. angustovittata and it breeds true to the type. (Illustrated) The eggs that had been subjected to the changed environment, fertilized with normal male germs produced mutants which breed true without subsequent segregation. In some cases the male germinal material was worked upon and in others the female substance. In some cases the change was shown in the first generation, in others successive generations were required. So long as there is no segregation or reversion after the mutation is produced the time required to fix the change is not of prime importance. Not all germ cells are modified. This may indicate differences between the eggs in their capacity for modification, or that only certain eggs were in the proper stage for modification at the time of the application of the experimental conditions. The results are sometimes modifications all in one direction, at other times they are in many directions, two, three, or more different forms arising from the same experiment. Some characters have no intergrades, others have intergrades and there is no place where one can draw a line and say that on one side all are discontinuous variations and on the other they are continuous".

In Blaringham's experiments to produce mutations by artificial means, he subjected indian corn (Zea Mays) to various mutilations. (I) The stalk was cut transversely near the ground through a greater or lesser part of its body. (2) The stalk was split longitudinally from near the ground upwards for varying distances. (3) The principle stalk was twisted about its own axis to varying degrees. (4) In reference to the ears alone the developing ear was twisted about its axis to varying degrees. Many striking variations were produced some of which breed true without regression or segregation. Four new forms have been produced which reproduce true to type. These differ in color of grain, character of growth, etc.

In the experiments briefly reviewed and others that might be cited we see that mutations have been produced by artificial means; striking variations from the parental form which breed true and become 
new elementary species. Seemingly the balance of the plant has been upset and new forms arise in consequence. Two striking facts were brought out in the reviews: in MacDougal's work the same new form was produced by various chemicals and even by distilled water (which may have been impure, however): In Tower's paper he states that the same experiment (the same treatment) may produce one or many forms. Evidently the principle use of artificial stimuli or mutilation is to upset the balance in the plant so that new forms may arise in consequence of a new balance. It seems to be but an academic statement to say that those treatments that have been successful in producing a mutation have affected the germ-plasm while those that produce changes that revert to the original type have not affected the germ-plasm but only the soma. To be of consequence to future generations the artificial condition must affect the germ-plasm.

The work of the writer on 'the influence which certain chemical injections may have on variation in plants' is briefly outlined under "Materials and Methods" of this paper. It will be recalled that some fifteen thousand plants were under careful observation throughout one season (the life time of the plants) for the purpose of noting any mutations which might occur. Approximately one half of these plants were from seeds from ovaries that had been chemically treated as outlined. The method of injecting the chemical into the ovary and the stimulants used were suggested by the work of MacDougal. The work was undertaken in the expectation that an extensive experiment of this kind would add to the sum of the knowledge along this line.

The plants under observation were for the most part remarkably uniform, which is to say that close scrutiny was necessary in order to detect differences of consequence. One striking variation was found which was repeated in several parts of the plot, but since it was found alike in lines from injected capsules and in lines from untreated capsules a full discussion of the type will be taken up in another part of this paper rather than in this chapter. Aside from the variation just mentioned there were found no types distinct enough to be considered as elementary species. The experiment did not duplicate the work of MacDougal in the matter of producing new forms by the injection method. It may be that Silene is more stable than the plants used by MacDougal (especially more stable than Oenothera) and is therefore not so easily upset in its chemical 
balance. It is possible too that a test of the plants in a second generation may show residual effects from the injection treatments.

In order to show that the injections did affect the plants to a great degree even though not sufficiently to produce mutations, the statistical method was adopted. The data obtained are shown in the tables of constants under "Materials and Methods". Since, as will be shown in chapter II, the plants in the whole experimental plat varied by lines, each line from an injected capsule is compared with a correspondling line from a capsule not injected. Which is to say that any comparison to be of value must concern the same mother- (second generation) plant. To group all plants from injected capsules together and compare them with all plants from capsules not injected would be of little value.

Let us compare then the treated and untreated capsuleprogeny of each of the mother plants.

\begin{tabular}{|c|c|c|c|c|c|c|}
\hline & & Pla & $\begin{array}{l}50-1 . \\
t\end{array}$ & & & \\
\hline & igree & Chem. & St. De & & Coef. of & Var. \\
\hline & I C 596 & $\mathrm{Ca}\left(\mathrm{NO}_{3}\right)_{2}$ & $4.210 \pm$ & 224 & $6.33 \pm$ & 337 \\
\hline & I C $58 \mathrm{I}$ & $\mathrm{ZnSO}_{4}$ & $4.954 \pm$ & 324 & $7.77 \pm$ & 509 \\
\hline & I C $59 \mathrm{r}$ & $\mathrm{H}_{2} \mathrm{O}$ & 5.9 I $2 \pm$ & 279 & $8.98 \pm$ & 424 \\
\hline & I C 598 & $\mathrm{Ca}\left(\mathrm{NO}_{3}\right)_{2}$ & $4.125 \pm$ & 227 & $6.05 \pm$ & 333 \\
\hline , & I a & - & $5.50 \mathrm{r} \pm$ & 185 & $8.58 \pm$ & 289 \\
\hline & & & & & & \\
\hline ," & I C 596 & $\mathrm{Ca}\left(\mathrm{NO}_{3}\right)_{2}$ & $3.437 \pm$ & 183 & $9.59 \pm$ & 5 II \\
\hline & I c $58 \mathrm{I}$ & $\mathrm{ZnSO}_{4}$ & $3.851 \pm$ & 252 & II. $44 \pm$ & 759 \\
\hline & I C 59 I & $\mathrm{H}_{2} \mathrm{O}$ & $3.161 \pm$ & I 49 & $8.87 \pm$ & 419 \\
\hline & I C 598 & $\mathrm{Ca}\left(\mathrm{NO}_{3}\right)_{2}$ & $3.123 \pm$ & 172 & $8.20 \pm$ & $45^{2}$ \\
\hline " & I a & - & $3.698 \pm$ & I 25 & $10.87 \pm$ & 367 \\
\hline & & $\mathrm{Numb}$ & ranches & & & \\
\hline & I C 596 & $\mathrm{Ca}\left(\mathrm{NO}_{3}\right)_{2}$ & $2.122 \pm$ & I I 3 & $10.53 \pm$ & 567 \\
\hline & I C $58 \mathrm{I}$ & $\mathrm{ZnSO}_{4}$ & $2.386 \pm$ & I 56 & I $3.08 \pm$ & 871 \\
\hline & I c 59 I & $\mathrm{H}_{2} \mathrm{O}$ & $2.04 \mathrm{I} \pm$ & 096 & $9.80 \pm$ & 463 \\
\hline & I c 598 & $\mathrm{Ca}\left(\mathrm{NO}_{3}\right)_{2}$ & $2.120 \pm$ & I 16 & $10.6 \mathrm{I} \pm$ & 590 \\
\hline " & I a & - & $1.653 \pm$ & 056 & $8.56 \pm$ & 289 \\
\hline & & $\mathrm{Numb}$ & ed Pods & & & \\
\hline & I C 596 & $\mathrm{Ca}\left(\mathrm{NO}_{3}\right)_{2}$ & $43.278 \pm$ & .308 & $18.10 \pm$ & 996 \\
\hline & I c $58 \mathrm{r}$ & $\mathrm{ZnSO}_{4}$ & $47 \cdot 547 \pm$ & 3. I I 5 & I $8.04 \pm$ & 1.219 \\
\hline & I C 59 I & $\mathrm{H}_{2} \mathrm{O}$ & $52.693 \pm$ & .488 & $19.24 \pm$ & $94 \mathbf{I}$ \\
\hline & I c 598 & $\mathrm{Ca}\left(\mathrm{NO}_{3}\right)_{2}$ & $50.460 \pm$ & 2.779 & $18.52 \pm$ & I. 054 \\
\hline$n$ & I a & - & $47.243 \pm$ & .593 & $20.35 \pm$ & .713 \\
\hline
\end{tabular}


We see here that so far as height and width are concerned the constants are no larger for the lines from injected capsules than for those from the uninjected. With the other two characters the treatment has increased the variability uniformly. It is also of interest to note that the two treatments of copper nitrate produced about an equal effect in each case both on the standard deviation and the coefficient of variability.

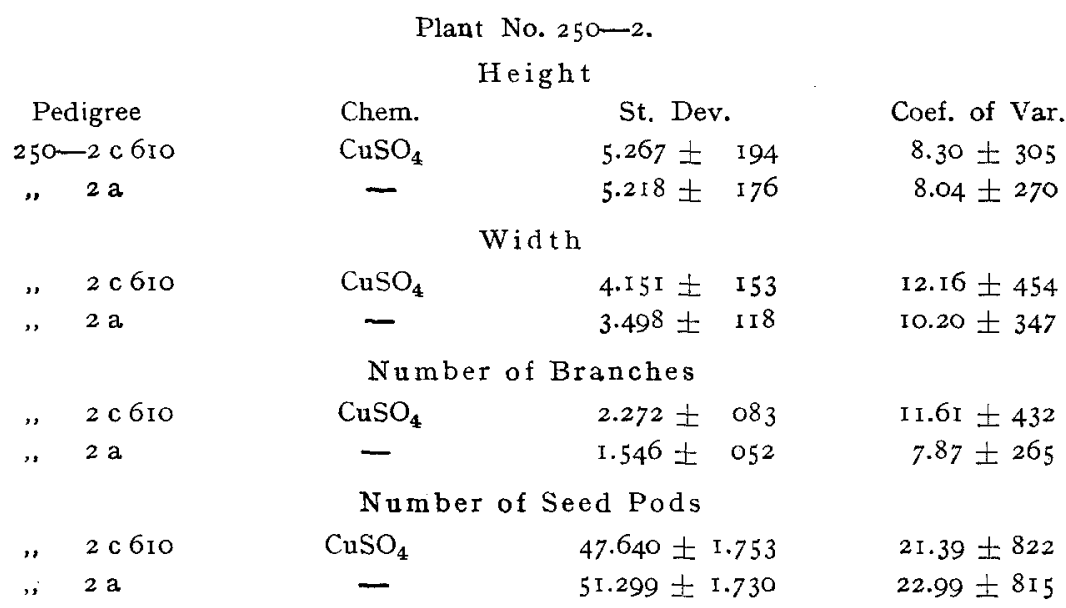

In this case both the standard deviation and the coefficient of variability are much larger for the plants from copper sulfate treated capsules than for those from untreated capsules, for three characters, and less for the character "number of seed pods". The treatment has increased the variability of the plants.

\begin{tabular}{|c|c|c|c|}
\hline \multicolumn{4}{|c|}{ Plant No. $250-5$} \\
\hline Pedigree & Chem. & St. Dev. & Coef. of Var. \\
\hline $250-5 \mathrm{c} 624$ & $\mathrm{ZnSO}_{4}$ & $5.27 \mathrm{I} \pm 20 \mathrm{I}$ & $8.9 \mathrm{I} \pm 3^{12}$ \\
\hline$" 5 \mathrm{c} 616$ & $\mathrm{C}_{2} \mathrm{HCl}_{3} \mathrm{O}+\mathrm{H}_{2} \mathrm{O}$ & $3.939 \pm 253$ & $6 . \mathrm{II} \pm 393$ \\
\hline $5 a$ & - & $5.035 \pm 170$ & $7.71 \pm 260$ \\
\hline \multicolumn{4}{|c|}{ Width } \\
\hline $5 c 624$ & $\mathrm{ZnSO}_{4}$ & $5.039 \pm 192$ & $14.83 \pm 576$ \\
\hline $5 \mathrm{c} 616$ & $\mathrm{C}_{2} \mathrm{HCl}_{3} \mathrm{O}+\mathrm{H}_{2} \mathrm{O}$ & $3.274 \pm 210$ & $8.97 \pm 577$ \\
\hline $5 \mathrm{a}$ & - & $4.211 \pm 142$ & $12.38 \pm 423$ \\
\hline \multicolumn{4}{|c|}{ Number of Branches } \\
\hline $5 \mathrm{c} 624$ & $\mathrm{ZnSO}_{4}$ & $2.159 \pm 082$ & II.I $7 \pm 430$ \\
\hline $5 \mathrm{c} 616$ & $\mathrm{C}_{2} \mathrm{HCl}_{3} \mathrm{O}+\mathrm{H}_{2} \mathrm{O}$ & $2.022 \pm 130$ & II.4I \pm 743 \\
\hline $5 a$ & - & $\mathrm{I} .48 \mathrm{I} \pm 050$ & $7.77 \pm 262$ \\
\hline
\end{tabular}


Number of Seed Pods

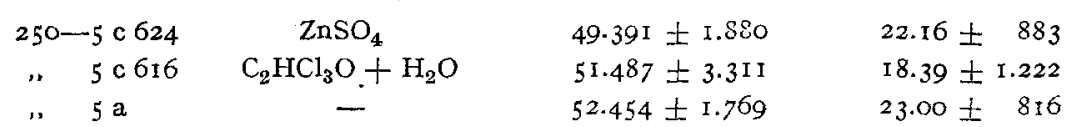

This table shows the zinc treatment to be much more generally effective than the chloral hydrate in increasing the variability. In nearly every case the former has made the constants larger than the check, while with the latter they are smaller.

\begin{tabular}{|c|c|c|c|c|c|}
\hline \multicolumn{6}{|c|}{$\begin{array}{c}\text { Plant No. } 250-6 . \\
\text { Height }\end{array}$} \\
\hline \multirow{2}{*}{$\begin{array}{c}\text { Pedigree } \\
250-6 \text { c } 627\end{array}$} & \multirow{2}{*}{$\begin{array}{l}\text { Chem. } \\
\mathrm{ZnSO}_{4}\end{array}$} & \multicolumn{2}{|c|}{ St. Dev. } & \multicolumn{2}{|c|}{ Coef. of Var. } \\
\hline & & $4 \cdot 430 \pm$ & 244 & $6.72 \pm$ & 370 \\
\hline . $6 \mathrm{a}$ & - & $4.035 \pm$ & 136 & $6.31 \pm$ & 2 I 3 \\
\hline \multicolumn{6}{|c|}{ Width } \\
\hline $6 \mathrm{c} 627$ & $\mathrm{ZnSO}_{4}$ & $4.071 \pm$ & 224 & $10.86 \pm$ & 517 \\
\hline $6 a$ & - & $3.604 \pm$ & $12 \mathrm{I}$ & $10.64 \pm$ & $36 \mathfrak{3}$ \\
\hline \multicolumn{6}{|c|}{ Number of Branches } \\
\hline $6 \mathrm{c} 627$ & $\mathrm{ZnSO}_{4}$ & $2.768 \pm$ & 152 & $14.20 \pm$ & 798 \\
\hline $6 a$ & - & $1.601 \pm$ & 054 & $8.41 \pm$ & 284 \\
\hline \multicolumn{6}{|c|}{ Number of Seed Pods } \\
\hline $6 \mathrm{c} 62^{-}$ & $\mathrm{ZnSO}_{4}$ & $62.694 \pm$ & .453 & $21.71 \pm 1$ & $.25 \mathrm{I}$ \\
\hline . $6 a$ & - & $56.125 \pm$ & .893 & $24.83 \pm$ & 886 \\
\hline
\end{tabular}

We find here that zinc sulfate has increased the standard deviation in each instance, and that it has increased the coefficient of variability in all instances except one.

\begin{tabular}{|c|c|c|c|c|c|}
\hline \multicolumn{6}{|c|}{$\begin{array}{c}\text { Plant No. } 250-7 \\
\text { Height }\end{array}$} \\
\hline \multirow{2}{*}{$\begin{array}{l}\text { Pedigree } \\
250-7 \text { c } 629\end{array}$} & \multirow{3}{*}{$\begin{array}{c}\text { Chem. } \\
\mathrm{Ca}\left(\mathrm{NO}_{3}\right)_{2} \\
\mathrm{H}_{2} \mathrm{O}\end{array}$} & \multicolumn{2}{|c|}{ St. Dev. } & \multirow{3}{*}{$\begin{array}{l}\text { Coef. of } \\
7.03 \pm \\
5.25 \pm\end{array}$} & \multirow{3}{*}{$\begin{array}{l}\text { Var. } \\
398 \\
382\end{array}$} \\
\hline & & $4.379 \pm$ & 248 & & \\
\hline . $7 \subset 639$ & & $3.467 \pm$ & 252 & & \\
\hline $7 a$ & - & $5.203 \pm$ & 175 & $7.95 \pm$ & 268 \\
\hline \multicolumn{6}{|c|}{ Width } \\
\hline $7 \mathrm{c} 629$ & $\mathrm{Ca}\left(\mathrm{NO}_{3}\right)_{2}$ & $4.334 \pm$ & 245 & I3.I5 士 & 757 \\
\hline 7 c 639 & $\mathrm{H}_{2} \mathrm{O}$ & $3.593 \pm$ & $26 \mathrm{r}$ & $11.33 \pm$ & 835 \\
\hline $7 \mathrm{a}$ & - & $4.37 I \pm$ & 147 & $12.71 \pm$ & 436 \\
\hline \multicolumn{6}{|c|}{ Number of Branches } \\
\hline 7 c 629 & $\mathrm{Ca}\left(\mathrm{NO}_{3}\right)_{2}$ & $2.368 \pm$ & I 34 & II. $78 \pm$ & 676 \\
\hline \# 7 c 639 & $\mathrm{H}_{2} \mathrm{O}$ & $2.079 \pm$ & $15 \mathrm{I}$ & $9.82 \pm$ & 714 \\
\hline$\therefore 7 a$ & - & $1.669 \pm$ & 056 & $8.66 \pm$ & 292 \\
\hline
\end{tabular}




\begin{tabular}{|c|c|c|c|}
\hline \multicolumn{4}{|c|}{ Number of Seed Pods } \\
\hline $250-7 \mathrm{c} 629$ & $\mathrm{Ca}\left(\mathrm{NO}_{3}\right)_{2}$ & $44.324 \pm 2.509$ & $20.18 \pm$ \\
\hline , $\quad 7 \mathrm{c} 639$ & $\mathrm{H}_{2} \mathrm{O}$ & $49.999 \pm 3.636$ & $19.25 \pm 1.450$ \\
\hline $7 a$ & - & $57.390 \pm I .935$ & $26.01 \pm 935$ \\
\hline
\end{tabular}

With plant No. $250-7$ the results are not of importance except that we see in practically every case a greater influence by calcium nitrate than by water.

\begin{tabular}{|c|c|c|c|c|}
\hline \multicolumn{5}{|c|}{$\begin{array}{c}\text { Plant No. } 250-8 . \\
\text { Height }\end{array}$} \\
\hline \multirow{2}{*}{$\begin{array}{c}\text { Pedigree } \\
250-8 \text { c } 644^{4}\end{array}$} & \multirow{3}{*}{$\begin{array}{l}\text { Chem. } \\
\mathrm{ZnSO}_{4} \\
-\end{array}$} & St. Dev. & \multicolumn{2}{|c|}{ Coef. of Var. } \\
\hline & & $5.360 \pm 348$ & $8.17 \pm$ & $53^{\circ}$ \\
\hline " $8 \mathrm{a}$ & & $5.389 \pm \quad 182$ & $8.29 \pm$ & 280 \\
\hline \multicolumn{5}{|c|}{ Width } \\
\hline $3<644$ & $\mathrm{ZnSO}_{4}$ & $2.749 \pm \quad \mathrm{I} / \mathrm{S}$ & $7.93 \pm$ & 515 \\
\hline $8 \mathrm{a}$ & - & $3.695 \pm 125$ & $10.49 \pm$ & 359 \\
\hline \multicolumn{5}{|c|}{ Number of Branches } \\
\hline $8 \mathrm{c} 644$ & $\mathrm{ZnSO}_{4}$ & $2.590 \pm 168$ & 12.1 $3 \pm$ & \\
\hline $8 \mathrm{a}$ & - & $1.535 \pm 052$ & $7.73 \pm$ & $26 \mathrm{I}$ \\
\hline \multicolumn{5}{|c|}{ Number of Seed Pods } \\
\hline , $8 \mathrm{c} 644$ & $\mathrm{ZnSO}_{4}$ & $48.854 \pm 3.17 \mathrm{I}$ & \multicolumn{2}{|c|}{$18.59 \pm \mathrm{I} .247$} \\
\hline$" 8 a$ & - & $47.075 \pm 1.591$ & \multicolumn{2}{|c|}{2 I.TI \pm 745} \\
\hline
\end{tabular}

Height

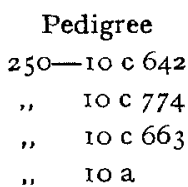

, 10 c 642

, I0 774

, Ioc 663

, I0 a

., Io c 642

, 100774

". Iо 663

.. IO
St. Dev.

$4.760 \pm 295$
$3.742 \pm 250$
$4.301 \pm 309$
$4.570 \pm 154$

Width

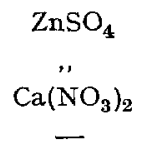

$4.555 \pm 283$

3.134士 209

$3.320 \pm 239$

$3.742 \pm 126$

Number of Branches

$\mathrm{ZnSO}_{4}$

$\mathrm{Ca}\left(\mathrm{NO}_{3}\right)_{2}$
$2.200 \pm \mathrm{I} 37$

$2.568 \pm$ I7 I

$1.665 \pm 120$

$1.516 \pm 05 \mathrm{I}$
Coef. of Var.

$7.29 \pm 453$

$5.67 \pm 379$

$6.60 \pm 474$

$6.95 \pm 234$

$$
\begin{array}{r}
14.16 \pm 896 \\
8.72 \pm 582 \\
9.48 \pm 681 \\
10.80 \pm 368
\end{array}
$$

$11.42 \pm \quad 718$
$13.21 \pm 897$
$8.76 \pm 630$
$7.76 \pm \quad 262$




\begin{tabular}{|c|c|c|c|c|}
\hline \multicolumn{5}{|c|}{ Number of Seed Pods } \\
\hline , & $10 \mathrm{c} 64^{2}$ & $\mathrm{ZnSO}_{4}$ & $55.55^{2} \pm 3.449$ & $20.21 \pm 1.305$ \\
\hline "f & IO c 774 & ", & $50.14^{8} \pm 3.349$ & $18.10 \pm 1.248$ \\
\hline ", & Iо c 663 & $\mathrm{Ca}\left(\mathrm{NO}_{3}\right)_{2}$ & $54.079 \pm 3.888$ & $19.36 \pm 1.443$ \\
\hline , & IO a & - & $50.036 \pm 1.687$ & $20.93 \pm 736$ \\
\hline
\end{tabular}

With plant No. 250-Io the injections have increased the standard deviation in ten cases out of twelve. The results as regards coefficient of variability are not so consistant; but since the number of variates are less in the injected lines than in the untreated the standard deviation seems to be the best measure of variability and we would say that variability is increased. Ofcourse, other things being equal the larger the population the larger will be the standard deviation.

\begin{tabular}{|c|c|c|c|c|c|c|}
\hline \multicolumn{7}{|c|}{ Plant No. 250 -II. } \\
\hline & digree & Chem. & \multicolumn{2}{|c|}{ St. Dev. } & Coef. of & Var. \\
\hline & - I c 67 I & $\mathrm{NaCl}$ & $5 \cdot 569 \pm$ & 239 & $8.36 \pm$ & 359 \\
\hline , & I I c 769 & $\mathrm{ZnSO}_{4}$ & $4.984 \pm$ & 228 & $7.59 \pm$ & 346 \\
\hline$"$ & II c 707 & $\mathrm{CaCl}_{2}$ & $5.045 \pm$ & 248 & $7.73 \pm$ & 380 \\
\hline , & I I a & - & $4.068 \pm$ & I 37 & $5.97 \pm$ & 201 \\
\hline \multicolumn{7}{|c|}{ Width } \\
\hline & - I I c 67 I & $\mathrm{NaCl}$ & $4.059 \pm$ & I 74 & II.20 \pm & 488 \\
\hline ," & I I c 769 & $\mathrm{ZnSO}_{4}$ & $3.956 \pm$ & I 81 & II. $85 \pm$ & 548 \\
\hline , & II c 707 & $\mathrm{CaCl}_{2}$ & $4.476 \pm$ & 220 & I $2.97 \pm$ & 649 \\
\hline , & I I & - & $3 \cdot 364 \pm$ & I I 3 & $9.62 \pm$ & 324 \\
\hline \multicolumn{7}{|c|}{ Number of Branches } \\
\hline , & II c 67 I & $\mathrm{NaCl}$ & $2.569 \pm$ & I IO & $12.70 \pm$ & 555 \\
\hline , & II c 769 & $\mathrm{ZnSO}_{4}$ & I. $822 \pm$ & 083 & $8.97 \pm$ & 410 \\
\hline , & II C 707 & $\mathrm{CaCl}_{2}$ & $2.560 \pm$ & 126 & $13.37 \pm$ & 670 \\
\hline , & I I a & - & $\mathrm{I} .49 \mathrm{I} \pm$ & 050 & $7.73 \pm$ & 261 \\
\hline \multicolumn{7}{|c|}{ Number of Seed Pods } \\
\hline ," & II c 67 I & $\mathrm{NaCl}$ & \multicolumn{2}{|c|}{$66.408 \pm 2.856$} & \multicolumn{2}{|c|}{$25.00 \pm$ I.I 39} \\
\hline ", & I I c 769 & $\mathrm{ZnSO}_{4}$ & \multirow{2}{*}{\multicolumn{2}{|c|}{$55.395 \pm 2.530$}} & \multicolumn{2}{|c|}{$20.55 \pm 977$} \\
\hline & I I C 707 & $\mathrm{CaCl}_{2}$ & & $60.119 \pm 2.957$ & \\
\hline , & I I a & - & \multicolumn{2}{|c|}{$34.880 \pm 1.176$} & \multicolumn{2}{|c|}{$\begin{array}{l}22.69 \pm 1.172 \\
15.61 \pm 539\end{array}$} \\
\hline
\end{tabular}

With plant No. 250-II the results of injection are most striking. The variability is markedly increased in each case both as measured by standard deviation and by coefficient of variability.

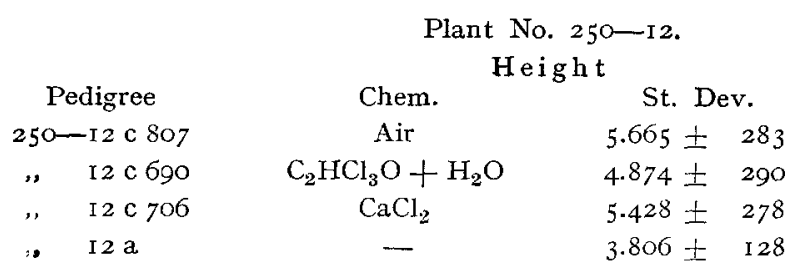

Induktive Abstammungs- und Vererbungslehre. IV.
Coef. of Var.

$8.88 \pm 444$

$4.60 \pm 274$

$8.00 \pm 446$

$5.56 \pm 187$

I 3 


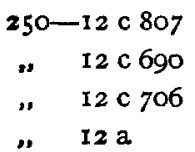

, $21 \mathrm{c} 807$

, 12 c 690

"I2 706

"I $2 \mathrm{a}$

" $\quad$ I 2 c 807
" $\quad$ I 2 c 690
" $\quad$ I 2 c 706
" $\quad$ I 2 a
Width

\begin{tabular}{|c|c|c|c|c|}
\hline Air & $4.665 \pm$ & 233 & $13.88 \pm$ & 707 \\
\hline $\mathrm{C}_{2} \mathrm{HCl}_{3} \mathrm{O}+\mathrm{H}_{2} \mathrm{O}$ & $4.240 \pm$ & 253 & II.99 \pm & 725 \\
\hline $\mathrm{CaCl}_{2}$ & $4.414 \pm$ & 246 & II.77 \pm & 666 \\
\hline- & $3.379 \pm$ & 114 & $9.62 \pm$ & 324 \\
\hline \multicolumn{5}{|c|}{ Number of Branches } \\
\hline Air & $2.429 \pm$ & 121 & $12.37 \pm$ & 627 \\
\hline $\mathrm{C}_{2} \mathrm{HCl}_{3} \mathrm{O}+\mathrm{H}_{2} \mathrm{O}$ & $2.348 \pm$ & 140 & $13.25 \pm$ & 803 \\
\hline $\mathrm{CaCl}_{2}$ & $2.256 \pm$ & 126 & $12.14 \pm$ & 688 \\
\hline- & $1.406 \pm$ & 047 & $7.25 \pm$ & 24 \\
\hline
\end{tabular}

Number of Seed Pods

$\begin{array}{cll}\text { Air } & 55.514 \pm 2.775 & 22.8 \mathrm{I} \pm \mathrm{I} . \mathrm{I} 99 \\ \mathrm{C}_{2} \mathrm{HCl}_{3} \mathrm{O}+\mathrm{H}_{2} \mathrm{O} & 54.72 \mathrm{I} \pm 3.262 & 22.48 \pm 1.407 \\ \mathrm{CaCl}_{2} & 49.985 \pm 2.790 & 17.98 \pm \mathrm{I} .035 \\ - & 40.126 \pm \mathrm{I} .353 & 20.00 \pm 700\end{array}$

The same consistent increase in variability due to injection noted for plant No. 250-II is seen here for plant No. 250-I2.

\begin{tabular}{|c|c|c|c|c|c|c|}
\hline \multicolumn{7}{|c|}{ Height } \\
\hline \multicolumn{2}{|c|}{ Pedigree } & Chem. & \multicolumn{2}{|c|}{ St. Dev. } & \multicolumn{2}{|c|}{ Coef. of Var. } \\
\hline 25 & -130710 & $\mathrm{MgSO}_{4}$ & $6.093 \pm$ & 303 & $9.33 \pm$ & 464 \\
\hline$"$ & I 3 C 736 & $\mathrm{FeSO}_{4}$ & $4.575 \pm$ & 2 I 5 & $6.69 \pm$ & 314 \\
\hline " & I 3 c 725 & $\mathrm{NaCl}$ & $4731 \pm$ & 175 & $6.97 \pm$ & 258 \\
\hline " & I 3 C 737 & $\mathrm{FeSO}_{4}$ & $6,073 \pm$ & .326 & $9.20 \pm$ & 494 \\
\hline$"$ & I $3 a$ & - & $4 \cdot 479 \pm$ & $.15 \mathrm{I}$ & $7.81 \pm$ & 263 \\
\hline \multicolumn{7}{|c|}{ Width } \\
\hline$"$ & $13 \mathrm{c} 7 \mathrm{ro}$ & $\mathrm{MgSO}_{4}$ & $2.6 \mathrm{I} 4 \pm$ & 130 & $7 \cdot 48 \pm$ & 372 \\
\hline " & I 3 c 736 & $\mathrm{FeSO}_{4}$ & $4.459 \pm$ & 209 & $12.14 \pm$ & 578 \\
\hline " & I 3 c 725 & $\mathrm{NaCl}$ & $3.836 \pm$ & 142 & I0.16 土 & 376 \\
\hline " & I 3 C 737 & $\mathrm{FeSO}_{4}$ & $4.946 \pm$ & 265 & I $3.59 \pm$ & 742 \\
\hline " & I3 a & - & 3.5 II \pm & I 18 & $10.79 \pm$ & 368 \\
\hline \multicolumn{7}{|c|}{ Number of Branches } \\
\hline$"$ & I3 C 7 IO & $\mathrm{MgSO}_{4}$ & $2.106 \pm$ & IO5 & $10.39 \pm$ & 523 \\
\hline " & $13 c 736$ & $\mathrm{FeSO}_{4}$ & I. $775 \pm$ & 083 & $8.21 \pm$ & 386 \\
\hline " & I 3 c 725 & $\mathrm{NaCl}$ & $2.181 \pm$ & $08 \mathrm{I}$ & $10.50-$ & 393 \\
\hline " & I $3 \subset 737$ & $\mathrm{FeSO}_{4}$ & $1.695 \pm$ & $09 \mathrm{I}$ & 8.13士 & 436 \\
\hline 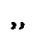 & I3a & - & $1.414 \pm$ & 048 & $7.00 \pm$ & 236 \\
\hline \multicolumn{7}{|c|}{ Number of Seed Pods } \\
\hline " & I 3 C 710 & $\mathrm{MgSO}_{4}$ & $59.910 \pm$ & .979 & $23.87 \pm$ & .252 \\
\hline ", & I 3 c 736 & $\mathrm{FeSO}_{4}$ & $47 \cdot 5^{6} 4$ 土 & .235 & I7.04 上 & 823 \\
\hline " & $13 C 725$ & $\mathrm{NaCl}$ & $60.128 \pm$ & .226 & 2 I. $54 \pm$ & 833 \\
\hline & I 3 c 737 & $\mathrm{FeSO}_{4}$ & $53.599 \pm$ & .876 & $21.84 \pm$ & .226 \\
\hline " & I3 a & - & $50.520 \pm$ & .704 & $27.50] \pm$ & 995 \\
\hline
\end{tabular}

The results here are not so consistent, yet in general there is increased variability. 
Plant No. $250-14$.

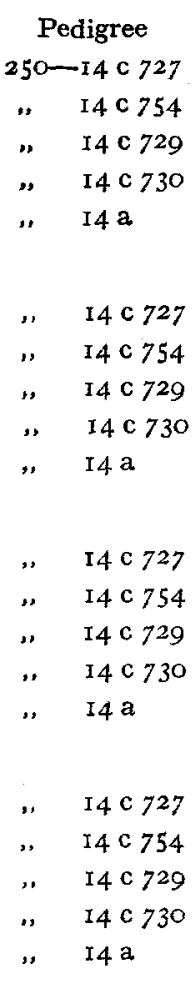

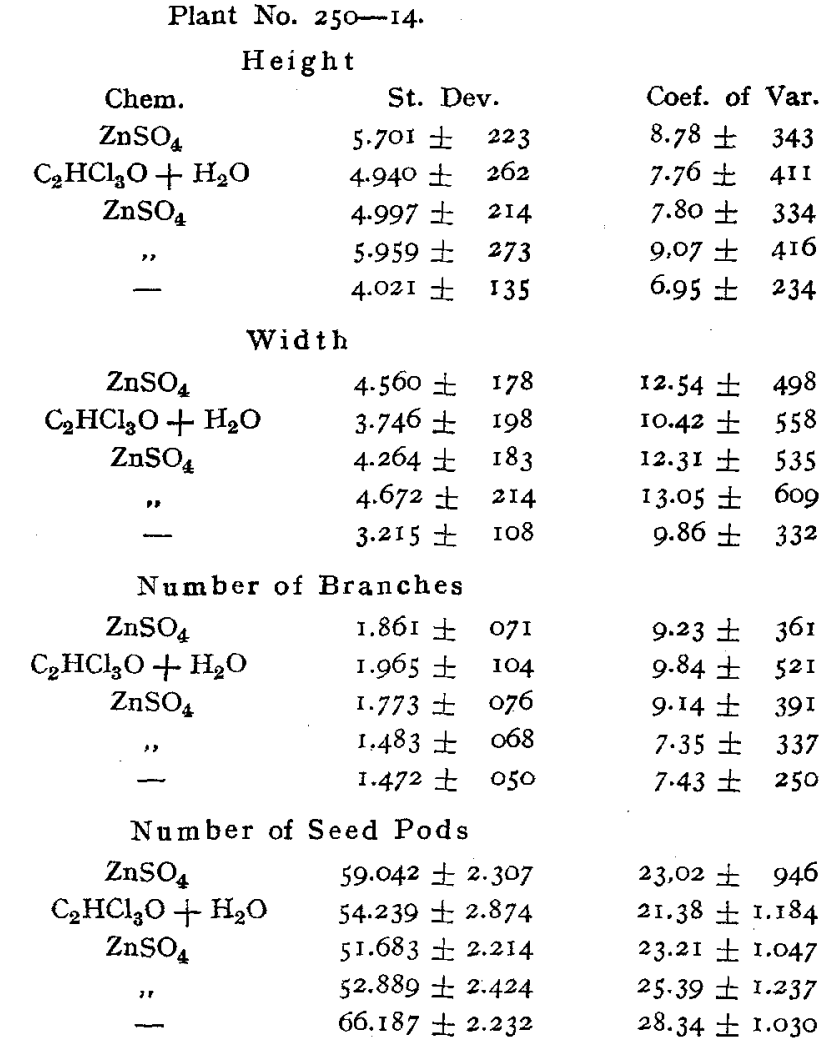

For the characters height, width, and number of branches, the injection treatments show marked increase in variability. For the character number of seed pods the treatments show less variation than the untreated. In nearly every case the chloral hydrate shows less effect than the zinc.

It is scarcely to be supposed that the injection of a stimulant into an ovary would make the progeny of that ovary less variable than the species. Results which tend to show such an effect must be put under the head of uncontrollable experimental error.

A much more minute and detailed analysis might be given here of these tables, taking up each constant and its probable error by itself. All of the data are presented so that such detail is easily obtainable by observation, therefore it seems that further discussion is unwarranted.

It was noted that the injections were more effective in increasing the variability in some lines than in others. A comparison of plants 
250-7 and 250-II shows this very plainly. Also that the same chemical does not produce an equal effect each time, even when used on the same plant. This may indicate differences in the condition of the buds at the time of treatment.

We may conclude that while the injection of chemical stimulants in the developing ovary did not, in the case of Silene noctiflora, produce mutations, such injections did produce in most cases a marked increase in the variability of the species. This change would be somewhat more strongly brought out were the lines of equal size and only the standard deviation used as the measure. In all cases the number of variates in the lines from injected capsules is less than lines from the uninjected.

\section{Effectiveness of Selection in pure lines.}

The question as to whether or not accumulative effects accrue from continued selection has long occupied an important place in discussions of inheritance. The general belief that mass selection is the surest if not the only method of improvement is shown over and over again by the practices of both practical breeders and experiment station workers. "Select the best and use this for the parent stock with the assurance that "like produces like" ", has been the gist of counsel. Darwin ${ }^{1}$ ) was firmly of the opinion that improvement has been brought about chiefly by the piling up of small favorable fluctuations and says, "We cannot suppose that all breeds were suddenly produced as perfect and as useful as we now see them, indeed in many cases we know that this has not been their history. The key is man's power of accumulative selection; nature gives successive variations; man adds them up in certain directions useful to him. If selection consisted merely in separating some very distinct variety and breeding from it, the principle would be so obvious as hardly to be worth notice; but its importance consists in the great effect produced by the accumulation in one direction, during successive generations, of differences absolutely inappreciable by an uneducated eye...."

Those who believe that accumulative effects do result from continued selection have had a strong champion in the statistical school. Galton's ${ }^{2}$ ) law of ancestral inheritance (somewhat modified by

1) Darwin, Chas., Origin of Species. Chap. r. pp 25-26.

2) Galton, Francis. Natural inheritance. I889. 
Pearson ${ }^{1}$ ) which states that the offspring inherits one half of its characteristics from its parents, one fourth from its grand parents, one eighth from its great-grand parents, etc., has had great influence in shaping the opinions of breeders and investigators. Allowing this law to hold good, it would be possible ofcourse to shift the mean of a race from generation to generation by selection. The question is, were the experiments upon which this law was built up and is being supported of the kind from which general conclusions should be drawn? As we will see many of the men who formerly worked with this so called "statistical school" are now among its strongest critics.

With the publication of the "Mutationstheorie“ by de Vries ${ }^{2}$ ) about the year Igoo new light began to be thrown upon the subject. De Vries believes that the shifting of a mean by selection can proceed only to a limited degree, and that when the selection is discontinued the mean will soon find its former position. He believes that selection alone cannot account for all of the facts of evolution, that experiments fail to show real accumulative effects, and he has gone further by showing experimentally that species may arise by sudden jumps or mutations.

At the Svalof Experiment Station ${ }^{3}$ ) striking results have been obtained by isolating types and multiplying the strains thus produced. The work of this station is in direct confirmation of the mutation theory.

Johannsen ${ }^{4}$ ) published in 1903 the results of some careful and extensive experiments with beans and barley which brought out the fact that especial attention should be given to the analysis of the experimental data before attempting conclusions. In his selection experiments he found the greatest difference in the behavior of the material, whether "pure lines" or "populations" were used. A pure line by definition is a self fertilized race which has come direct from a single seed. A population is a mixture of lines. His experiments duplicated the results of Galton where populations were used, but gave no results from selection in pure lines. Which is to say that the attempts to shift the mean of a pure line were unsuccessful.

\footnotetext{
1) Pearson, Karl. Biometrica.

2) Vries, Hugo de. Die Mutationstheorie. I903.

3) Vries, Hugo de. Plant Breeding, pp. 29-106. (1907. Open Court Chicago.)

4) Johannsen, W. Uber Erblichkeit in Populationen und in reinen Linien. (1903. Verlag von Gustav Fischer in Jena.)
} 
Jennings 1 ) in his experiments with the common infusorian Paramecium published in 1908, found, as did Johannsen, that from a mixed population pure lines may be isolated, which will breed true and not revert to the mean of the original population even when selection is discontinued. Selection within the pure lines was ineffective.

Pearl ${ }^{2}$ ) has recently shown that there is no cumulative effect where Domestic Fowls are selected for fecundity. More than this, he shows that fowls that are the result of such selection are more variable for this character than fowls that are not the result of such selection.

Hanel ${ }^{3}$ ) with Hydra, and Love ${ }^{4}$ ) with peas, have found the same general rcsults to obtain.

All of these experiments which point to the lack of cumulative effect show that all of the experiments usually cited to prove that cumulative effects do accrue, are subject to the explanation that the results are due to the more or less complete isolation of pure lines from a mixed population.

The work of the author with Silene noctiflora offers some data on the subject. By comparing the measurements taken on the mother plants (table No. 2) with the means of the lines from untreated capsules of the next generation (tables Nos. 8, 9, Io and II) the following curves are produced. Fig. No. I is for the character "height", No. 2 is for "width", No. 3 "number of branches", and No. 4 is for the character "number of seed pods". In each case the solid line represents the measurement of the mother plants, arranged so as to form an ascending series, and the broken line represents the mean af the corresponding progeny.

Were there an inheritance of the characters in question between mother plants and their progeny the lines would run more or less parallel. This they do not do, especially in cases of Fig. 3 (number of branches) and Fig. 4 (number of seed pods). In these instances the "best straight lines" diverge more and more from each other.

1) Jennings, H. S. Heredity, Variation, and Evolution in Protozoa. II. Proc. Amer. Phil. Soc. 47:393-546. 1908.

2) Pearl, Raymond. Is there a Cumulative Effect of Selection? Zeitschr. Ind. Abstammungs- und Vererbungslehre. Band II. Heft 4.

3) Hane1, Elise. Vererbung bei ungeschlechtlicher Fortpflanzung von Hydra grisea. Jenaische Zeitschr. 43:321-372. 1907.

4) Love, H. H. Are Fluctations Inherited? American Naturalist. July I9Io. 
A quantitative Study of Variation, Natural and Induced, etc.

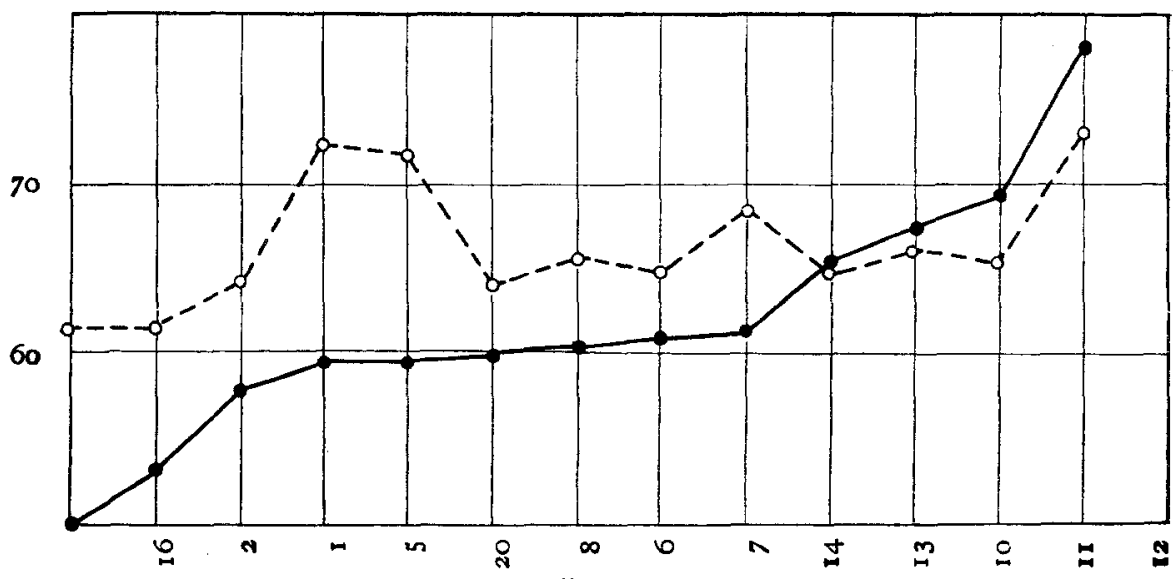

Fig. I.

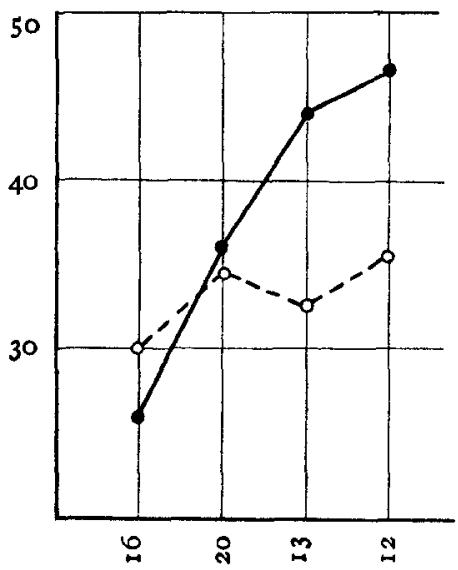

Fig. 2.

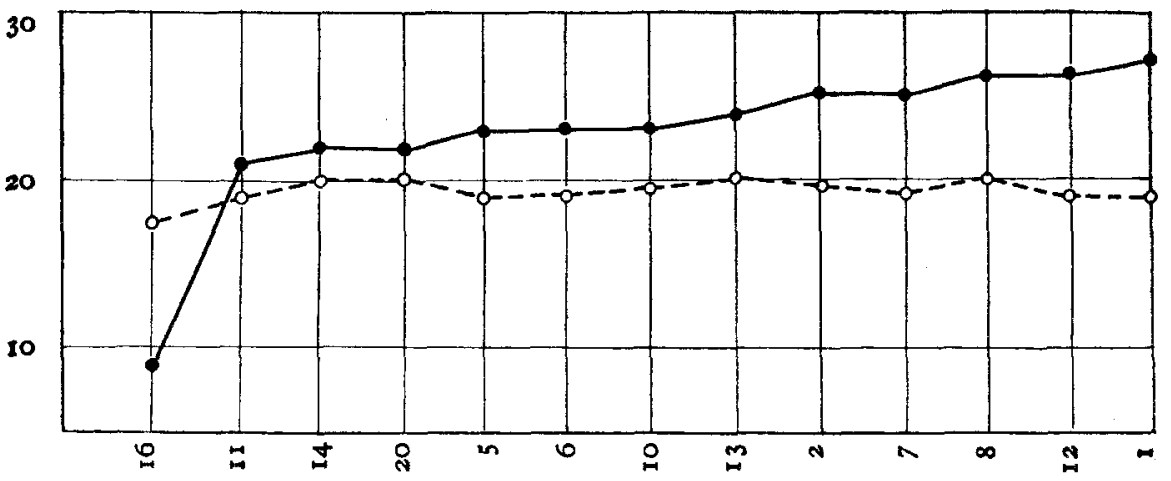

Fig. 3 . 
The lines 250-I6a and 250-20a may be studied further with profit. We have seen (table No. 2) that mother plant 250-I6 was a dwarfed plant with few branches and few seed pods, and that mother plant $250-20$ was a large upright plant. The progeny of these two plants along with that of $250-I_{4}$, which is inserted for

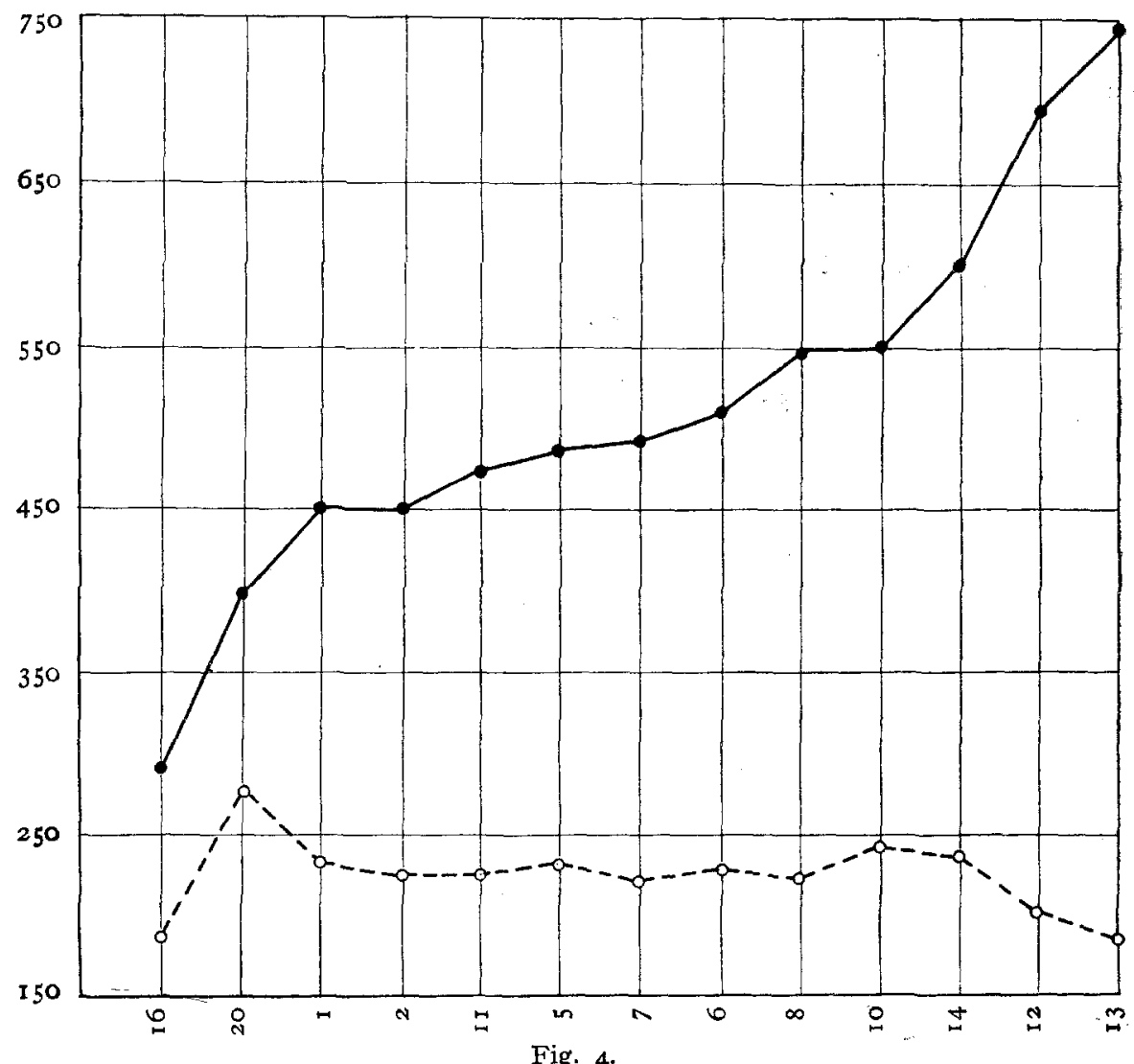

a check as being about the average of the lot, are shown in the following curves. Fig. 5 represents the character "height", Fig. 6 "width", Fig. 7 ,number of branches", and Fig. 8 "number of seed pods". In each Figure the solid line represents the progeny $250-\mathbf{r}_{4} \mathrm{a}$, the broken line represents progeny 250-r6a and the dot-and-dash line represents progeny 250-20a.

For the constants, mean, standard deviation, and coefficient of variability, with their respective probable errors, of these three lines, the reader is refered to tables $8,9,10$, and II. It will be seen that 
250-16a has great variability, and is inclined to break up into two distinct types, as witnessed by the bi-modal curves. 250-20a has but little variability and is decidedly uni-modal. The differences between these lines, and this tendency of $250-16 \mathrm{a}$ to break up into two types

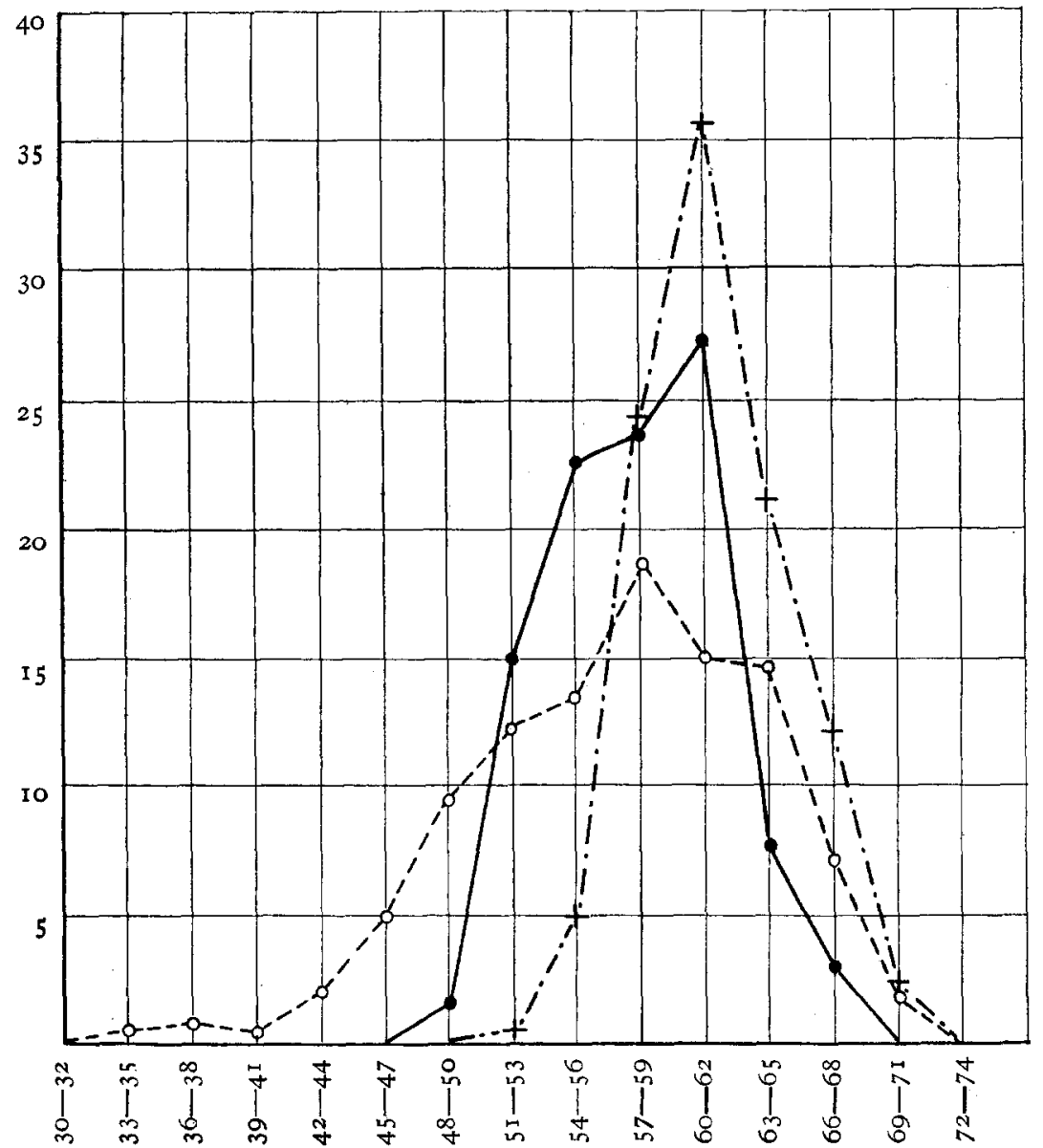

Fig. 5 .

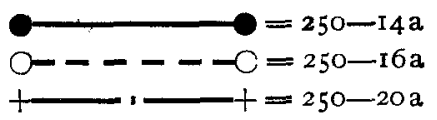

are more plainly shown by the use of correlation tables. Tables I3 to $2 \mathrm{I}$ inclusive represent the facts. (See correlation tables page 2I6.) Notice that in each table that concerns 250-r6a (tables I6, I7, and $I 8$ ) there is a decided indication that the line tends to produce 
two types for each of the characters studied. This tendency was also plainly marked in the experimental field as large and small plants were found in each row of 250-I6a and in any section of each row. This is shown by a glance at table I2 which gives some of the figures recorded in the field note book.

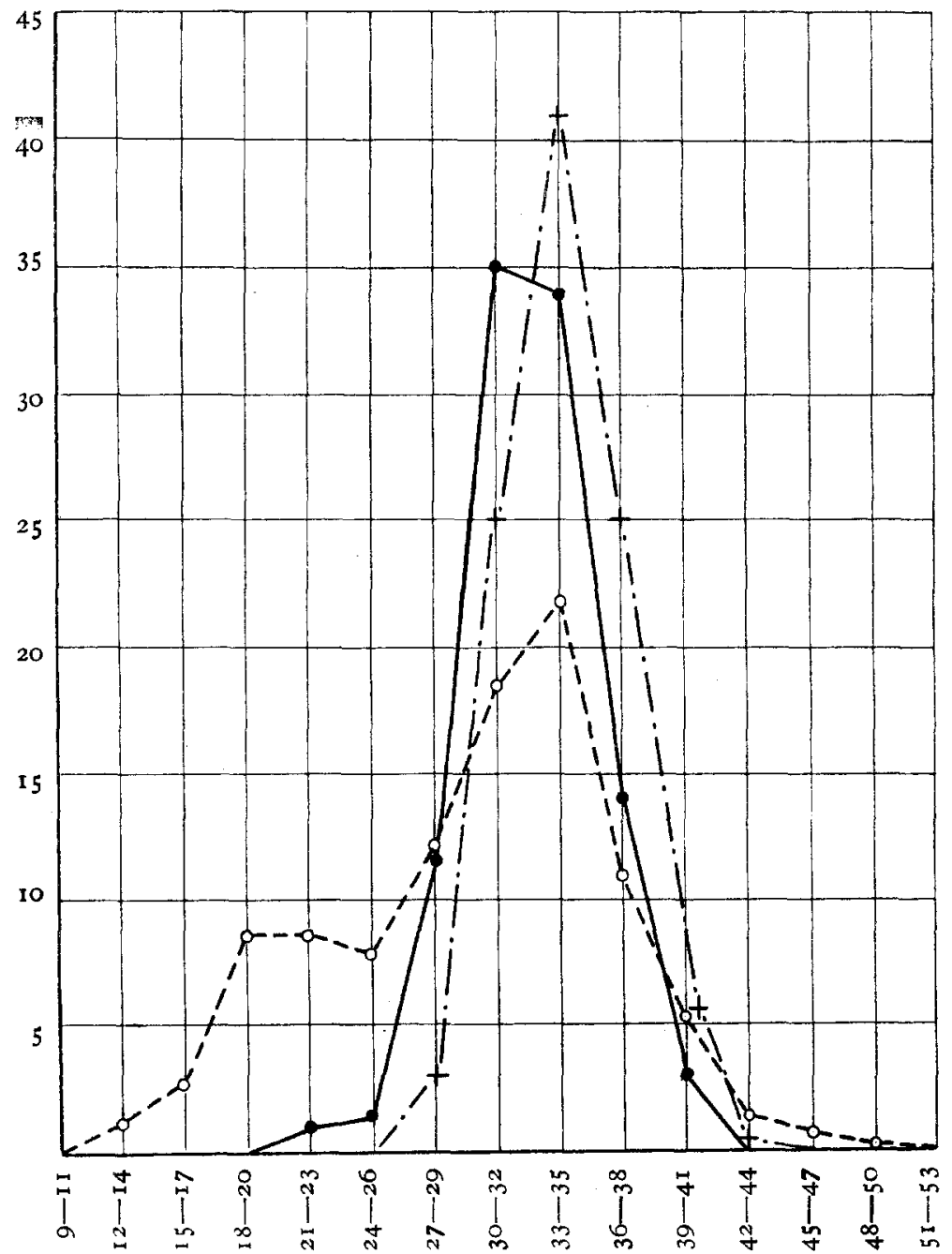

Fig. 6 .

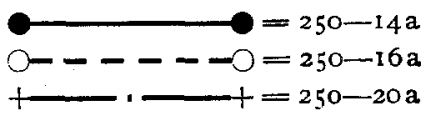


The progeny of mother plant 250-16 is not representative of the characters of that plant, but two types are produced which may or may not breed true to type. This remains to be tested out by further experiments.

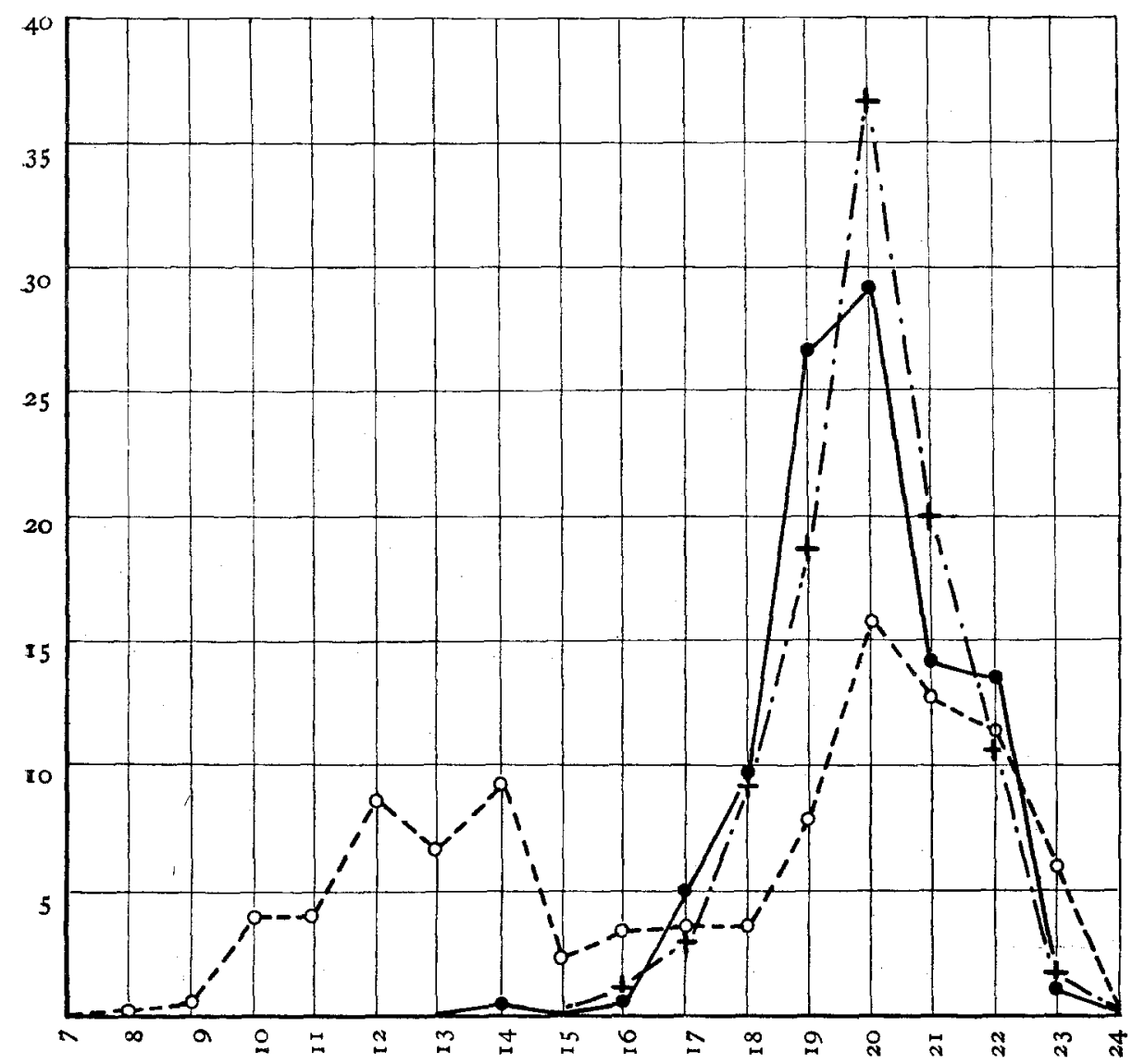

Fig. 7 .

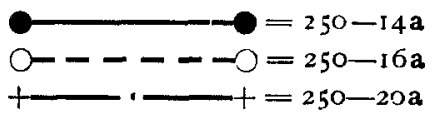

The fact was previously stated in this paper that a certain striking variation was found, both in lines from treated capsules and in a line from an untreated capsule. Figures 9, Io, and II are inserted to illustrate this variation or mutation. 


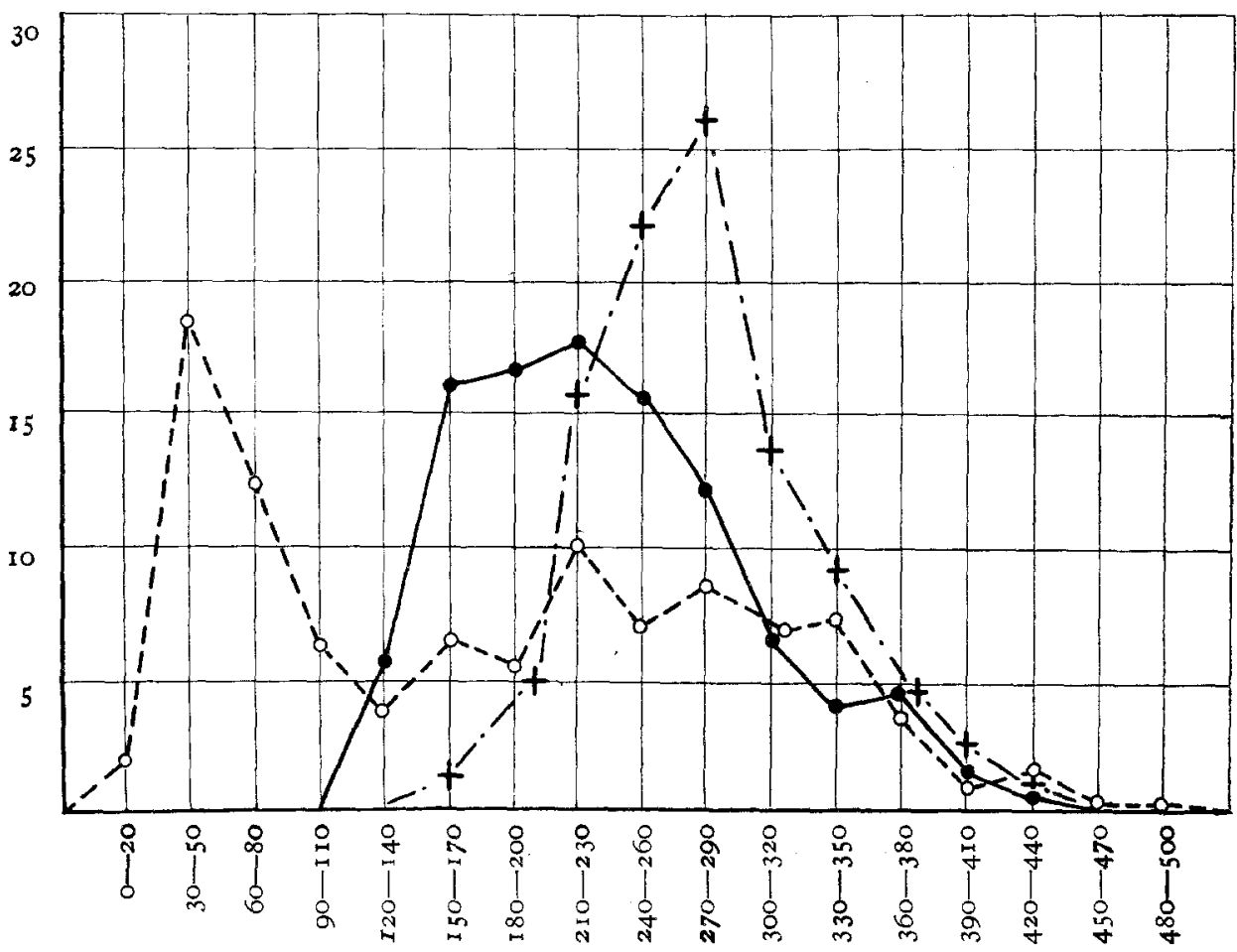

Fig. 8.

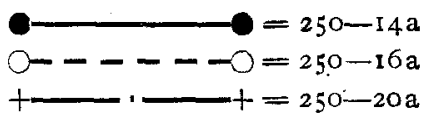

Table rz.

\begin{tabular}{|c|c|c|c|c|c|c|}
\hline \multicolumn{3}{|c|}{ Pedigree } & $\begin{array}{c}\text { Height } \\
\mathrm{cm} .\end{array}$ & $\begin{array}{c}\text { Width } \\
\mathrm{cm} .\end{array}$ & Branches & Seed Pods \\
\hline \multicolumn{3}{|c|}{$250-16 a-28$} & 61.0 & 34.0 & 20 & 344 \\
\hline 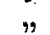 & $\eta$ & 29 & 67.0 & 34.0 & I9 & 308 \\
\hline$"$ & 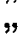 & 30 & 47.5 & 23.5 & I 2 & 56 \\
\hline$\because$ & 9 & $3 I$ & 53.5 & $3 I .0$ & 12 & 63 \\
\hline$"$ & 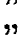 & 32 & 65.0 & 36.5 & $2 \mathrm{I}$ & 430 \\
\hline$"$ & $"$ & 33 & 55.5 & 22.0 & I6 & 68 \\
\hline$"$ & $"$ & 34 & 46.5 & 25.5 & I4 & 86 \\
\hline$"$ & $"$ & 35 & 67.0 & 39.5 & $2 I$ & 443 \\
\hline$\eta$ & " & 36 & 50.5 & 23.5 & I3 & 75 \\
\hline$n$ & $"$ & 37 & 44.5 & 23.5 & I 3 & 53 \\
\hline$\eta$ & $"$ & 38 & 65.0 & 36.0 & $2 I$ & 333 \\
\hline$"$ &, & 39 & 64.5 & 31.5 & 20 & 391 \\
\hline 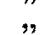 & 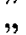 & 40 & 65.5 & 35.5 & 23 & 378 \\
\hline$\%$ & " & $4 \mathrm{I}$ & 49.0 & 24.0 & I 3 & 78 \\
\hline
\end{tabular}


Fig. No. 9 represents the mutant ( $\mathrm{I}$ ); and the normal type of the species (2). Differences in leaf form, thickness of stem, character of branch termination, and productiveness are shown. Fig. No. Io shows in more detail the difference in the branch termination, and

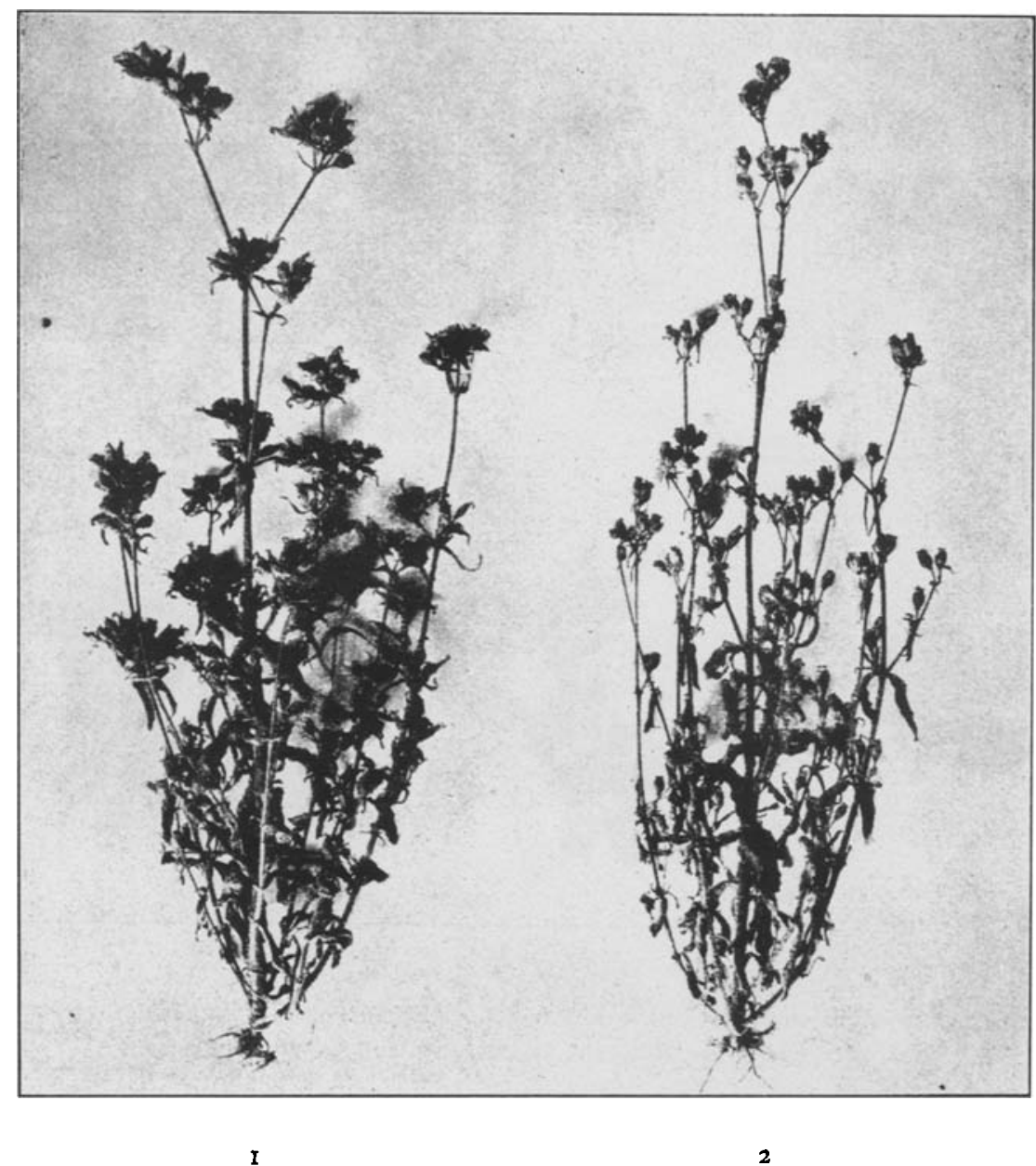

Fig. 9. No. I is plant $250-5 a-245$; No. 2 is plant $250-5 a-244$.

the number of seed pods found in typical clusters. Those from plant No. 250-5a-244 represent the normal type of the species, while those from plant No. 250-5a-245 represent the mutation.

Fig. No. II represents the five mutations of this type found and the pedigree number attached gives the relationships of the plants. 
$250-5 a-245$ comes from a capsule that was untreated. The others are from capsules that were treated with one or another of several different chemicals.

Table No. 28 shows the productiveness of these mutations in "number of seed pods" produced.
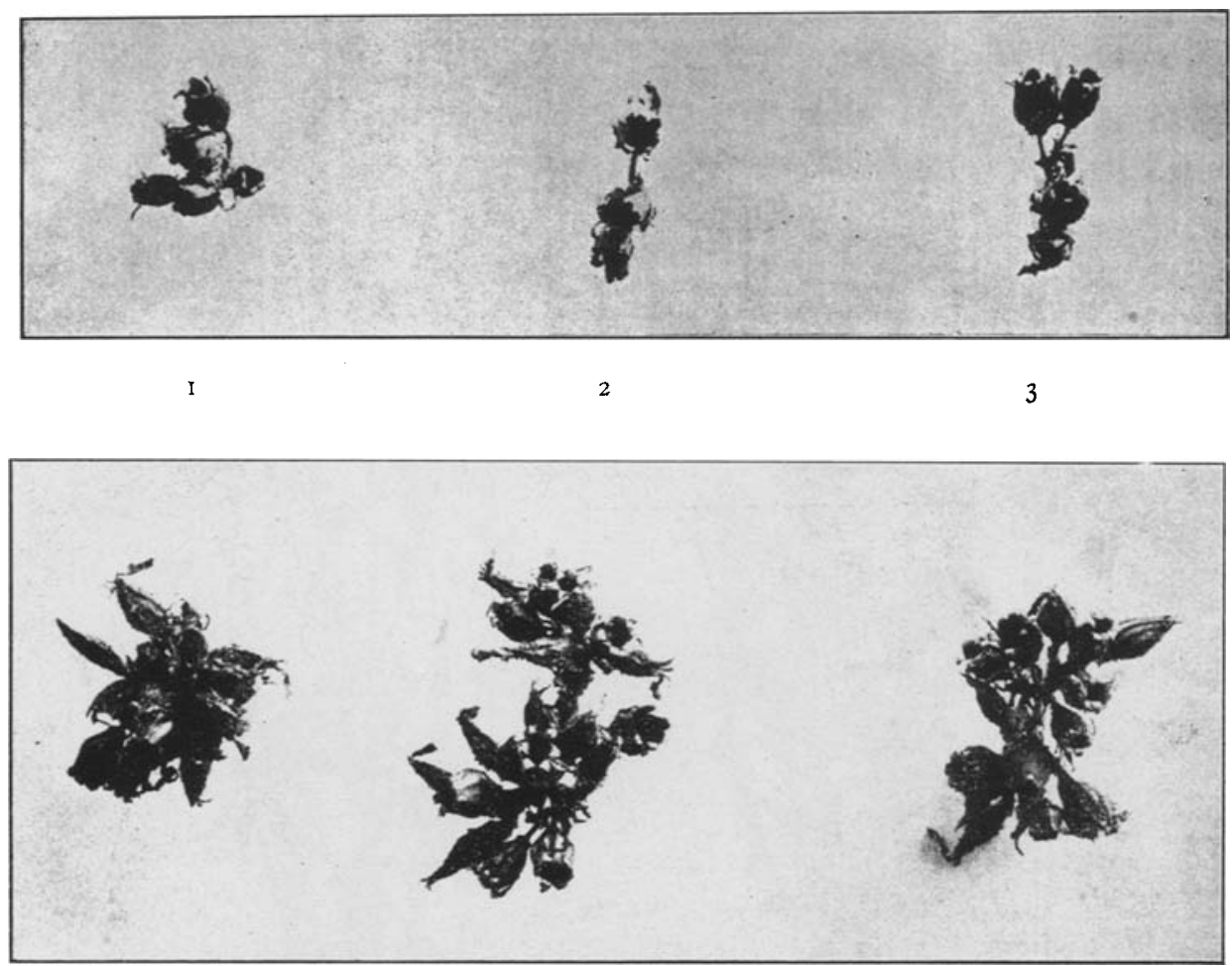

4 5

6

Fig. 10. This shows the character of the inflorescence of plants $250-5 \mathrm{a}-245$ and $250-5 \mathrm{a}-244$. Nos, 1,2 and 3 are from the latter, 4,5 and 6 from the former.

\section{Table 28 .}

\begin{tabular}{|c|c|}
\hline \multirow{2}{*}{\multicolumn{2}{|c|}{$\begin{array}{r}\text { Pedigree } \\
250-5 a-245\end{array}$}} \\
\hline & \\
\hline$\because$ & $14 \mathrm{C} 730-115$ \\
\hline פ" & I4C $75 \mathrm{I}-54$ \\
\hline : & $14 c 724-134$ \\
\hline "צ & I 3 c $737-88$ \\
\hline
\end{tabular}

Seed Pods
322
525
529
670
793

That this is much larger production than usual is shown by the fact that but three of the normal type plants produced as many as 


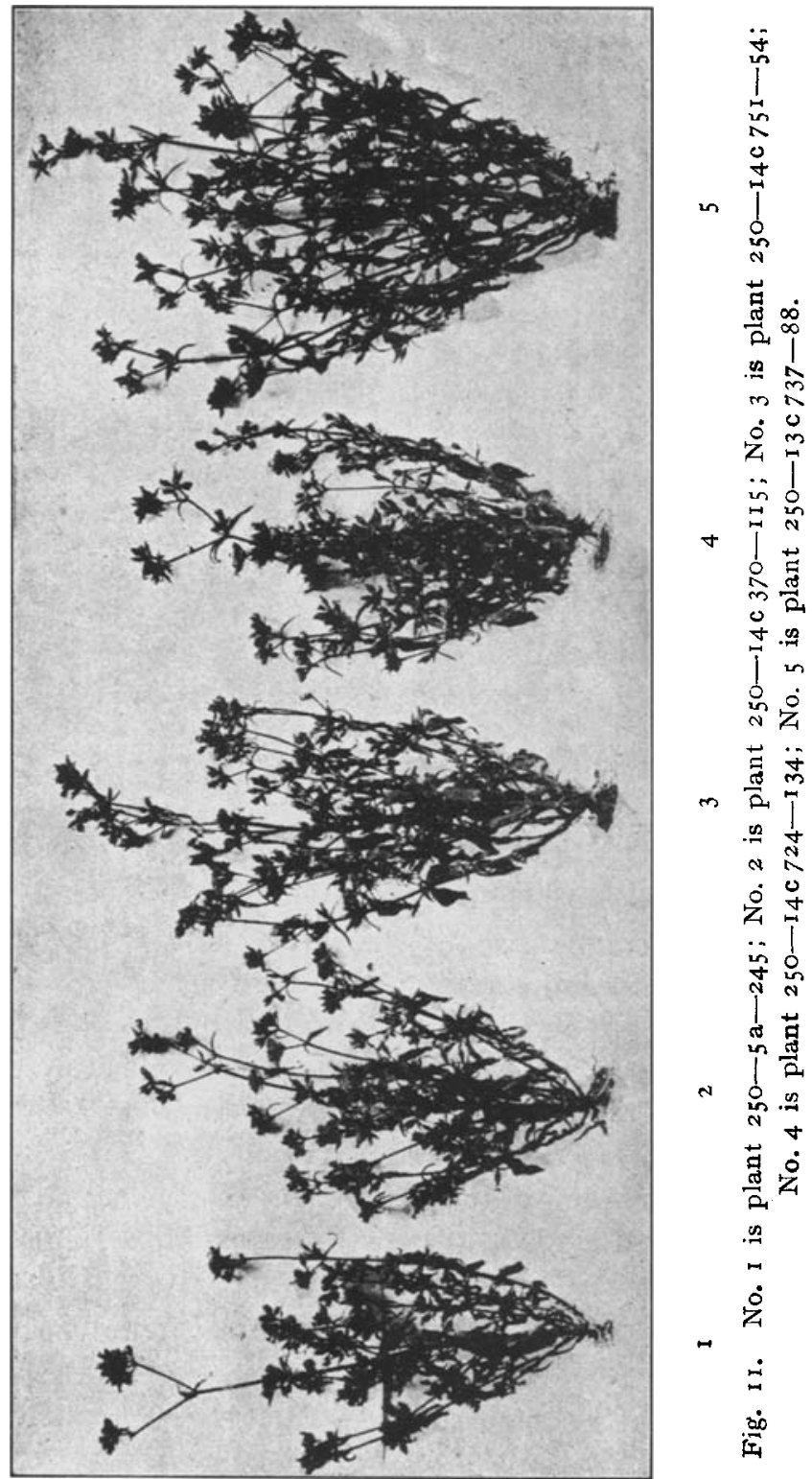


480 seed pods, while but eight produced more than 450 . (See table No. 7.)

The terms "mutation" and striking variation have been used in describing the new form. That it will breed true to type and thus answer the requirements of a "mutation" has not been proved, hence the term striking variation is to be preferred. Young seedlings from this type, however, growing in the green house with normal seedlings do show a consistant difference.

\section{Bud Variation.}

It is not the purpose of this chapter to give a full review of the subject of bud variation. Without going into the different theories as to the cause of these variations, or giving a catalogue of the important ones listed in literature, we may discuss them as real facts in existence. Webber ${ }^{1}$ ) has pointed out the possible analogy between bud variation and seedling variation as follows: „From our present knowledge of the cytology of heredity we would assume that hereditary changes such as those manifested by bud variation as well as seedling variations are due to rearrangements of the hereditary units or anlagen which occur during cell division. In the case of seedling variation we assume that this rearrangement takes place primarily during the progress of the reduction division that preceeds the formation of the sexual cells. So far as microscopic investigations go we have no evidence that would strengthen the idea of such a redistribution of characters ever taking place in the somatic cells. However, we have the strongest of all possible proofs that it does occur in the fact that in bud variation we get segregation of character analogous to the segregation in seedlings. In hybrids the characters very frequently segregate in the somatic cells giving branches resembling the pure parental characters which reproduce these characters through the seed. Cytological evidence against the possibility or probability of such an occurence is of no value in the face of its actual occurance".

East ${ }^{2}$ ) gives practically the same thought in this quotation: "The investigations reported in the foregoing pages suggest very forcibly that the behavior of variations reproduced by budding is in

1) Webber, H. J. Clonal or Bud Variation. Amer. Breeders Asso. 5:347357. 1909.

2) East, E. M. The Transmission of Variations in the Potato in Asexual Reproduction. Connecticut Exp. Sta. Rep. 1909-1910. 
many ways essentially like that of variations coming from seed. The inherited variations that were found have all but one concerned characters that mendelize in sexual reproduction, and as there is no evidence upon the inheritence of the one exception, it may be left out of consideration .... It follows that segregation may occur in the somatic cells, and that by division of one of these somatic cells a line of descendants originates lacking a Mendelian character that is present in the parent cell. The fact does not develope anything new in regard to the relative importance of the chromosomes and the cytoplasm as bearers of hereditary characters, but it certainly seems to show that Mendelian segregation is not limited to the reduction division in the maturation of sexual cells."

If bud variation and seedling variation may be treated as analogous the measurement of one should be as important as the measurement of the other. In fact it seems that greater care should be exercised in distinguishing the one from the other. It seems quite certain that what is in fact due to bud variation is often listed as due to seedling variation.

It is an easy matter to note the extent of bud variation when the plant is reproduced by vegetative parts, but it is more difficult when sexually produced seeds are used in reproduction. Which is to say that differences in seedlings may be due to bud variation on the mother plant, but owing to the fact that the reduction division processes have since taken place we are prone to list these differences as seedling variations. Suppose, however, that all of the seedlings from one bud (capsule) vary about a certain mean and that seedlings from another bud (capsule) vary about a different mean. Have we not in such a case an evidence of bud variation on the mother plant carried forward by means of sexually produced seeds? A study based on this hypothesis is here reported.

It was stated in "Materials and Methods" of this paper that six self fertilized capsules were collected from each of the three mother plants, 250-II, 250-I2, and 250-I3. The pure lines produced from these six capsules of each mother plant offer instructive data regarding the extent of bud variation on said mother plants. A comparison of the constants is the method used for the interpretation of the facts. 
Plant No. 250-II.

$\mathrm{Height}$

\begin{tabular}{|c|c|c|}
\hline \multirow{2}{*}{\multicolumn{2}{|c|}{$\begin{array}{c}\text { Pedigree } \\
250-\text { I I U }\end{array}$}} & Mod \\
\hline & & 61 \\
\hline ", & I I $\mathrm{V}$ & $6 \mathrm{I}$ \\
\hline " & II W & 55 \\
\hline ." & I I X & 55 \\
\hline, & I I $\mathrm{Y}$ & $5^{8}$ \\
\hline ", & I I $Z$ & 55 \\
\hline , & I I $U$ & $3^{I}$ \\
\hline ", & II $\mathrm{V}$ & 28 \\
\hline " & I I $W$ & 25 \\
\hline ", & I I $\mathrm{X}$ & 28 \\
\hline " & I I $Y$ & 31 \\
\hline " & I I $Z$ & \\
\hline " & I I U & 19 \\
\hline ", & I I V & 1 \\
\hline " & II $W$ & \\
\hline " & I I $\mathbf{X}$ & 19 \\
\hline ", & I I $\mathbf{Y}$ & 19 \\
\hline$"$ & I I $Z$ & \\
\hline$"$ & I I $U$ & 70 \\
\hline$"$ & II $\mathrm{V}$ & \\
\hline " & I I W & \\
\hline " & II $\mathrm{X}$ & \\
\hline " & II $\mathbf{Y}$ & \\
\hline " & I I 2 & \\
\hline
\end{tabular}

Mean
$59.140 \pm 323$
$58.483 \pm 265$
$58.308 \pm 319$
$56.980 \pm 255$
$58.076 \pm 256$
$55.034 \pm 308$
Width

St. Dev.

$4.796 \pm 229$

$4.7 \mathrm{O} 2 \pm 187$

$5.120 \pm 226$

$4.680 \pm \mathrm{I} 8 \mathrm{O}$

$3.374 \pm 18 \mathrm{I}$

$4.302 \pm 217$

$25.660 \pm 39 \mathrm{I}$

$27.140 \pm 306$

$27.051 \pm 384$

$25.43 \mathrm{I} \pm 308$

$26.86 \mathrm{I} \pm 354$

$25.337 \pm 418$

$5.795 \pm 276$

$5.434 \pm 217$

$6.160 \pm 272$

$5.65 \mathrm{r} \pm 218$

$4.660 \pm 250$

$5.854 \pm 296$
$\mathrm{Number}$ of Branches

\begin{tabular}{|c|c|c|c|}
\hline $18.120 \pm$ & $14 \mathrm{I}$ & $2.085 \pm$ & 099 \\
\hline $18.203 \pm$ & IO3 & $1.834 \pm$ & 073 \\
\hline $8.624 \pm$ & 120 & $1.929 \pm$ & 085 \\
\hline $17.850 \pm$ & 099 & 1.8 I $4 \pm$ & 070 \\
\hline $18.696 \pm$ & 142 & $1.87^{8} \pm$ & IOI \\
\hline I $7.809 \pm$ & I 30 & $1.823 \pm$ & 092 \\
\hline \multicolumn{4}{|c|}{ Number of Seed Pods } \\
\hline $94.600 \pm$ & 2.019 & $29.8 \mathrm{r} 3 \pm$ & 1.422 \\
\hline $109.23 I \pm$ & 1.983 & 35.16 & 1.402 \\
\hline 103.333 土 & 2.043 & $32.764 \pm$ & I. 445 \\
\hline $89.608 \pm$ & I. 353 & $24.810 \pm$ & 957 \\
\hline $85.190 \pm$ & 1.488 & $19.607 \pm$ & I. 052 \\
\hline 79.101 & I. 683 & $23.542 \pm$ & I.190 \\
\hline
\end{tabular}

Plant No. 250-12.

$\mathrm{Height}$

\begin{tabular}{ccc}
\multicolumn{2}{c}{ Pedigree } & Mode \\
$250-12 \mathrm{U}$ & 61 \\
" & $12 \mathrm{~V}$ & 58 \\
" & I2 $\mathrm{W}$ & 55 \\
" & 12 X & 55 \\
" & $12 \mathrm{Y}$ & 55 \\
" & $12 \mathrm{Z}$ & 55 \\
& & \\
" & $12 \mathrm{U}$ & 28 \\
" & $12 \mathrm{~V}$ & $3 \mathrm{I}$ \\
" & $12 \mathrm{~W}$ & 25 \\
" & $12 \mathrm{X}$ & 28 \\
" & $12 \mathrm{Y}$ & 25 \\
. & $12 \mathrm{Z}$ & 25
\end{tabular}

Mean

$61.609 \pm \quad 428$

$59.34 \mathrm{I} \pm 355$

$57.315 \pm 279$

$56.073 \pm 35 \circ$

$56.09 \mathrm{I} \pm 280$

Width

$28.609 \pm 446$

$29.200 \pm 394$

$27.339 \pm 333$

$27.317 \pm 374$

$25.457 \pm 348$

$26.473 \pm 348$
$55.437 \pm 280$
St. Dev.

$5.273 \pm 303$

$4.859 \pm 25 \mathrm{I}$

$4.660 \pm 197$

$5.753 \pm 247$

$5.102 \pm 198$

$4.352 \pm 198$

$5.570 \pm 236$

6.154 土 265

$6.345 \pm 246$

$5.408 \pm 246$
$5.491 \pm 315$

$5.390 \pm 279$
Coef. of Var.

$8 . I I \pm 387$

$8.04 \pm 321$

$8.78 \pm 387$

$8.21 \pm 316$

$5.8 \mathrm{I} \pm 312$

$7.82 \pm 395$

$22.58 \pm$ I.I 31

$20.02 \pm 829$

$22.77 \pm 1.055$

$22.22 \pm 857$

$17.35 \pm 95^{8}$

$23.10 \pm 1.229$

I. $51 \pm 556$

$10.07 \pm 406$

I0. $36 \pm 462$

10.16士 396

I0.04士 544

I0.24 \pm 523

$31.51 \pm 1.644$

$32.19 \pm 1.412$

$31.7 \mathrm{I} \pm 1.53 \mathrm{I}$

$27.69 \pm 1.147$

$23.01 \pm 1.299$

$29.76 \pm 1.632$

Coef. of Var. $8.56 \pm 49 \mathrm{I}$ $8.19 \pm 424$

$8.13 \pm 344$

$10.26 \pm 446$

$9.20 \pm 357$

$7.76 \pm 353$

$19.19 \pm 142$

I8.46 \pm 986

$20.37 \pm 897$

$22.53 \pm 1.017$

$24.92 \pm 1.025$

$20.43 \pm \quad 967$ 
Number of Branches

$\begin{array}{rrr}250-12 \mathrm{U} & 19 \\ " & 12 \mathrm{~V} & 19 \\ " & 12 \mathrm{~W} & 18 \\ " & 12 \mathrm{X} & 18 \\ , & 12 \mathrm{Y} & 17 \\ " & 12 \mathrm{Z} & 18 \\ & & \\ " & 12 \mathrm{U} & 100 \\ " & 12 \mathrm{~V} & 100 \\ , & 12 \mathrm{~W} & 70 \\ " & 12 \mathrm{X} & 100 \\ " & 12 \mathrm{Y} & 70 \\ \text { " } & 12 \mathrm{Z} & 70\end{array}$

\begin{tabular}{|c|c|}
\hline $18.986 \pm$ & 128 \\
\hline I $8.459 \pm$ & I 5 I \\
\hline I $8.315 \pm$ & 102 \\
\hline $17.903=$ & 128 \\
\hline 17.324 & 108 \\
\hline 17.718 & I 33 \\
\hline
\end{tabular}

\begin{tabular}{|c|c|}
\hline I. $583 \pm$ & 091 \\
\hline $2.067=$ & 107 \\
\hline 1.701 & 072 \\
\hline 2.112 & O9I \\
\hline 1.96 & 076 \\
\hline 068 & 094 \\
\hline
\end{tabular}

$8.34 \pm 479$

Ir.20 586

$9.29 \pm 393$

I1.80 $\pm \quad 514$

$11.34 \pm \quad 446$

Number of Seed Pods

$91.304 \pm 2.159$

$26.589 \pm 1.527$

I I. $67 \pm 538$

$94.94 \mathrm{I} \pm 2.163$

$93.858 \pm \mathrm{I} .69 \mathrm{I}$

$94.146 \pm 1.797$

$87.086 \pm 1.412$

$86.909 \pm 1.656$
$29.570 \pm 1.530$

$28.258 \pm 1.196$

$29.547 \pm 1.271$

$25.724 \pm 998$

$25.752 \pm$ I.I7I
$29.12 \pm 1.809$

$31.14 \pm 1.766$

3O.II $\pm 1.3^{85}$

$31.38 \pm 1.476$

$29.54 \pm 1.24 \mathrm{I}$

$29.63 \pm 1.460$

\begin{tabular}{|c|c|c|}
\hline & igree & Mode \\
\hline & -I $3 U$ & 58 \\
\hline " & $13 \mathrm{~V}$ & 58 \\
\hline ", & I $3 \mathrm{~W}$ & 61 \\
\hline ", & I3X & 58 \\
\hline ", & I $3 \mathbf{Y}$ & 55 \\
\hline " & I $3 \mathbf{Z}$ & $6 \mathrm{I}$ \\
\hline " & I $3 \mathbf{U}$ & 28 \\
\hline ", & I $3 \mathrm{~V}$ & 28 \\
\hline " & $13 \mathrm{~W}$ & $3^{I}$ \\
\hline ", & $13 X$ & 31 \\
\hline " & I $3 \mathbf{Y}$ & 22 \\
\hline , & I $3 Z$ & 28 \\
\hline " & I $3 \mathrm{U}$ & 18 \\
\hline ", & I $3 \mathrm{~V}$ & 17 \\
\hline " & I $3 \mathrm{~W}$ & 18 \\
\hline " & I $3 X$ & I8 \\
\hline$"$ & I $3 \mathbf{Y}$ & 17 \\
\hline " & I $3 Z$ & I 8 \\
\hline " & I $3 U$ & 100 \\
\hline ", & I $3 \mathrm{~V}$ & 70 \\
\hline " & $13 \mathrm{~W}$ & 70 \\
\hline " & I $3 \mathbf{X}$ & 70 \\
\hline " & I $3 Y$ & 70 \\
\hline " & I $3 Z$ & 70 \\
\hline
\end{tabular}

Plant No. 250-13.

$\mathrm{Height}$

$\begin{array}{cc}\text { Mean } \\ 6.200 \pm & 331 \\ 6.672 \pm & 316 \\ 6.846 \pm & 370 \\ 6.784 \pm & 274 \\ 6.196 \pm & 267 \\ 6.859 \pm & 352\end{array}$

\section{Width}

$27.310 \pm 363$
$27.656 \pm 348$
$28.743 \pm$
$28.649 \pm 301$
$26.475 \pm 290$
$28.228 \pm 320$

$5.381 \pm 257$

$5.700 \pm 246$

$6.644 \pm 293$

$5.431 \pm 213$

$5.816 \pm 205$

$4.559 \pm 227$

Number of Branches

$\begin{array}{ll}17.660 \pm 128 & 1.904 \pm 091 \\ 17.402 \pm \text { II9 } & 1.957 \pm 084 \\ 17.761 \pm \text { I27 } & 2.041 \pm 090 \\ 17.507 \pm \text { III } & 1.995 \pm 078 \\ 17.470 \pm 078 & 1.576 \pm 055 \\ \text { I7.794 } \pm \text { I } 49 & 2.119 \pm 105 \\ \text { Number of Seed Pods } \\ 89.800 \pm 1.599 & 23.706 \pm 1.131 \\ 86.967 \pm 1.920 & 31.438 \pm 1.357 \\ 90.257 \pm 1.876 & 30.084 \pm 1.326 \\ 81.757 \pm 1.403 & 25.301 \pm 992 \\ 80.328 \pm 1.114 & 22.346 \pm 788 \\ 82.065 \pm 2.509 & 35.678 \pm 1.774\end{array}$

Coef. of Var.

$$
\begin{array}{r}
8.74 \pm \quad 417 \\
9.14 \pm \quad 395 \\
10.44 \pm \quad 465 \\
8.70 \pm 341 \\
9.54 \pm 336 \\
8.79 \pm 437
\end{array}
$$

$19.70 \pm 976$

$20.6 \mathrm{I} \pm 926$

23.II \pm 1.072

$18.96 \pm 769$

$21.97 \pm 811$

I6.I5

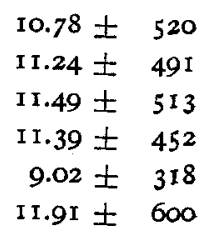

$26.40 \pm 1.345$

$36.15 \pm 1.751$

$33.33 \pm 1.624$

$30.95 \pm 1.323$

$27.82 \pm 1.053$

$43.47 \pm 2.537$ 
We see that all of the constants, mode, mean, standard deviation, and coefficient of variability, for each of the six progenies of each of the three mother plants, vary greatly one from another. In the cases studied the buds seem to have varied almost as much on one plant as they do between different plants.

While this data is not sufficient from which to draw iron-clad conclusions, yet there is enough to be very suggestive. To what extent may the plant be said to behave as an individual? is a question for further investigation.

\section{Influence of food supply on Variation.}

The author wishes to include in Chapter IV that part of the data obtained from this study of Silene noctiflora which bears more or less directly upon the question of food supply as affecting variability. "More or less directly", because in the "good soil" and "poor soil" plots spoken of in this chapter there were other differences besides that of food supply. Table 3 under "Materials and Methods" gives the chemical analysis of the two fields, Plant Breeding Garden and Mitchell Farm, upon which the Silene experiment plots were located. Referring back to that table we see that as regards potassium and phosphorus they are about equal, the garden plot having a little more potassium and a little less phosphorus than the Mitchell Farm plot. Comparing the two as to organic matter content we see that the garden plot is much the richer as shown by the figures $9.35 \%$ and $5.56 \%$. Along with this difference in the amount of organic matter we naturally find a much higher percentage of nitrogen in the garden soil. The figures are $.25 \%$ and .I3 \% N. Likewise high content of organic matter means large water holding capacity. It is readily seen that from the standpoint of chemical analysis we are justified in considering one soil much better adapted to plant growth that the other. The difference in favor of the Garden plot over the Mitchell Farm plot is also brought out by a casual examination of the two soils and the size and thrift of the plants growing thereon.

Comparing then pure line 250-IIa, which was grown on the garden plot, with pure lines $220-I I U, 250-I I V, 250-I I W, 250-I I X$, 250-IIY, and 250- IIZ, which were grown on the Mitchell Farm plot, we get a measure of the influence which this difference of food supply had upon the variability of the lines. The two constants, 
standard deviation and coefficient of variability, are used in the comparison, and the pure lines from three different mother plants, 250-II, 250-I2, and 250-I3 are given in the following table. In order that the table may be made as simple and as easily understood as possible the lines $\mathrm{U}, \mathrm{V}, \mathrm{W}, \mathrm{X}, \mathrm{Y}$, and $\mathrm{Z}$ are taken together and the average of the six used in each of the three cases. The figures are all taken from tables No. 8, 9, Io, and II.

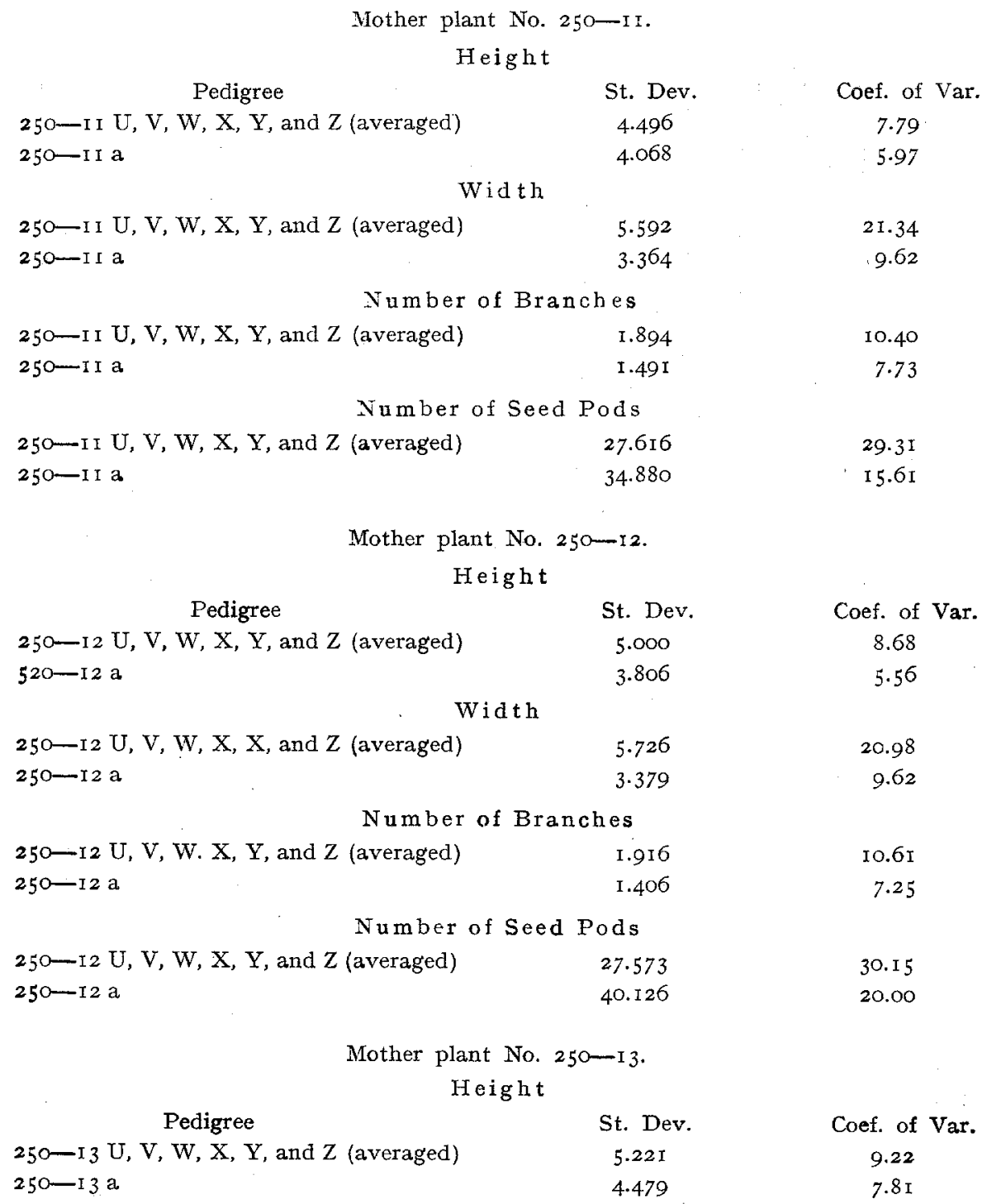

Mother plant No. 250-i2.

$$
\text { Height }
$$

Pedigree

250-I $2 \mathrm{U}, \mathrm{V}, \mathrm{W}, \mathrm{X}, \mathrm{X}$, and $\mathrm{Z}$ (averaged)

$520-12$ a

250-i 2 U, V, W, X, X, and $Z$ (averaged)

$250-12 \mathrm{a}$

St. Dev.

5.000

3.806

Width

$5 \cdot 726$

3.379

Number of Branches

Number of Seed Pods

250- $22 \mathrm{U}, \mathrm{V}, \mathrm{W}, \mathrm{X}, \mathrm{Y}$, and $\mathrm{Z}$ (averaged)

Mother plant No. 250-I3.$$
\text { Height }
$$

\section{Pedigree}

250-I $3 \mathrm{U}, \mathrm{V}, \mathrm{W}, \mathrm{X}, \mathrm{Y}$, and $\mathrm{Z}$ (averaged)

$250-13$ a

St. Dev.

5.221

4.479

20.98

9.62

$10.6 \mathrm{I}$

7.25

20.00 


\begin{tabular}{|c|c|c|}
\hline $2 I_{4}$ & & \\
\hline \multicolumn{3}{|c|}{ Width } \\
\hline $250-13 \mathrm{U}, \mathrm{V}, \mathrm{W}, \mathrm{X}, \mathrm{Y}$, and $\mathrm{Z}$ (averaged) & 5.588 & 20.08 \\
\hline $250-13 a$ & $3.5 \mathrm{II}$ & 10.79 \\
\hline \multicolumn{3}{|c|}{ Number of Branches } \\
\hline $250-13 U, V, W, X, Y$, and $Z$ (averaged) & I.932 & 10.96 \\
\hline $250-13 a$ & 1.414 & 7.00 \\
\hline \multicolumn{3}{|c|}{ Number of Seed Pods } \\
\hline $250-\mathrm{I} 3 \mathrm{U}, \mathrm{V}, \mathrm{W} X, \mathrm{Y}$, and $\mathrm{Z}$ (averaged) & 28.092 & 33.02 \\
\hline $250-13 a$ & 50.520 & 27.50 \\
\hline
\end{tabular}

We see that for each character for each line studied the coefficient of variability is greater in those lines from the Mitchell Farm (poor soil) than in those lines from the Plant Breeding Garden (good soil). Using the standard deviation as the index of variability the results are almost as striking though not quite so consistent. The standard deviation is greater for three of the characters out of four, in the lines grown on the Mitchell Farm plots. This is true for each pair used in comparison. The standard deviation for the character "number of seed pods", however, is greater in each case for the lines grown upon the Garden plot.

It should be pointed out that the lines grown upon the Mitchell Farm plot contained a much smaller number of variates than the lines grown upon the Garden plot. This is shown in tables No. 4, No. 5, No. 6, and No. 7. From this cause alone the Mitchell Farm lines would have somewhat smaller standard deviations. Without putting too much weight upon this fact, we may at least say that it reduces the difference which is in favor of greater variability in case of good soil as shown by the character "number of seed pods".

In nearly all of the comparisons made, then, the constants for the poor soil lines are very much greater than the corresponding constants for the good soil lines. This is contrary to the generally accepted idea that increase in nutrition is the principle cause for increase in variability. This idea was first expressed as a law by Knight ${ }^{1}$ ). It was adhered to by early writers and by Chas. Darwin ${ }^{2}$ ) who states that "of all the causes which induce variability, excess of food, whether or not changed in nature, is probably the most powerful." Within the last few years definitely planned experiments have been reported which give evidence, one way or the other upon

1) Knight, T. A. Treaties on the Culture of the Apple.

2) Darwin Chas. Animals and Plants under Domestication. Vol, II page 236. 
this subject of food supply as it may influence variability. Jennings ${ }^{\mathbf{1}}$ ) states that in Paramecium the characters do not all respond in the same way, some showing an increase and some showing a decrease in variability as the nutrition is changed. Reinohl') found in studying the effects of nutrition on the variability of the number of stamens of Stellaria media that the increase of the food supply gave a larger index of variability. In other words, the plants which had the excess food supply were more variable than those poorly fed. Davenport ${ }^{3}$ ) after conducting extensive experiments with corn (Zea Mays) concludes that "variability is not markedly increased by fertility." Love ${ }^{4}$ ) in studies with peas, buckwheat, asters, and corn under three conditions of food supply: namely, sand untreated soil, and heavily manured soil, finds that the increase in food supply has increased the variability in the great majority of cases under observation.

We would expect that as variability increases the correlation between characters would decrease. We find that this relation exists in the Silene plants studied. This is shown by referring to tables 22 to 27 inclusive. The following figures represent a summary of the correlation constants for these tables.

\begin{tabular}{|c|c|c|c|c|c|c|c|c|}
\hline $250-$ I I U &. .2 & Heigh & oject & Width re & elative & $\mathbf{r}$ & is & \\
\hline $250-$ I I a & & " & , & ". & ", & $\mathbf{r}$ & is & $3^{8}$ \\
\hline 250 -I I U &...$Z$ & ", & " & Branches & , & $\mathbf{r}$ & is & \\
\hline $250-1$ I a & & ", & " & ," & ", & $\mathbf{r}$ & is & \\
\hline $250-\mathrm{IIU}$ &.$\cdot z$ & ", & , & Seed Pods & relative & $\mathbf{r}$ & is & \\
\hline $250-11 \mathrm{a}$ & &, & , & , & " & $r$ & is & \\
\hline
\end{tabular}

We see here as stated above that as the variability increased the coefficient of correlation decreased, or in other words, that the garden plot (good soil) gave less variability and greater correlation of characters than did the plot on the Mitchell farm (poor soil).

It is of course recognized that in this Silene experiment reported, the difference between the Plant Breeding Garden and the Mitchell Farm plots does not rest alone in a difference in food supply. It includes also the points of temperature, moisture, physical condition, etc., etc. We know however that under one set of conditions the

1) Jennings, H. S. Heredity, Variation, and Evolution in Protozoa. II. Proc. Amer. Phil. Soc. Vol. 47:479. 1908.

2) Reinohl, F. Die Variation im Androceum der Stellaria media. Bot. Zeit. 1903 page I 59.

3) Davenport, E. and Rietz, H. L. Type and Variation in Corn, Bul. Ill. Exp. Sta. No. I 19.

4) Love, H. H. Studies in Variation. Doctorate thesis, Cornell University. Igog. 
available food supply is largcr than under the other set of conditions, and it seems proper to consider the different factors collectively as having direct bearing upon the available food supply.

It is quite possible that the transplanting process affected those plants put out on the Mitchell Farm differently from those put out on the Plant Breeding Garden. The difference in moisture and temperature conditions between soils rich and poor in organic matter is considerable. For this reason the results here reported may not be comparable with other results where the plants used were not transplanted. However, observation at the time of transplanting did not reveal any striking difference in the behavior of the plants on the different plots. The plants started off nicely in each case but grew faster in the Plant Breeding Garden than on the Mitchell Farm Plot.

The experimental data reported here is not exhaustive nor the results necessarily conclusive, yet there is certainly an indication that with Silene noctiflora under the conditions maintained during this experiment, increase in the food supply has decreased rather than increased variability.

\section{Correlation Tables.}

Table $\times 3$.

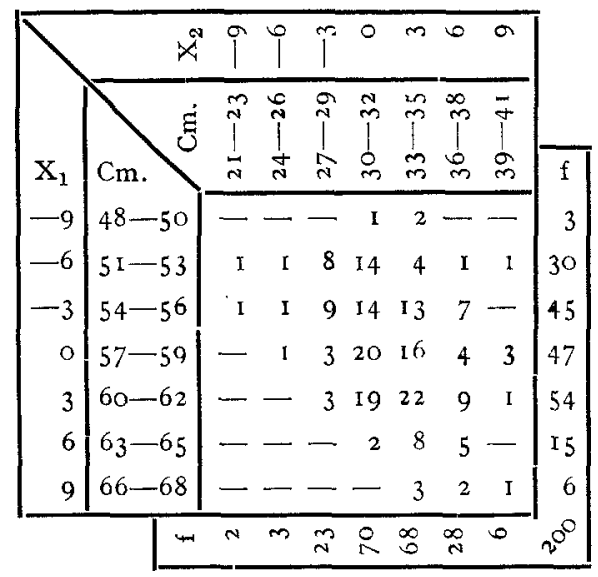

Correlation in $250-14 a$.

Height $=$ Subject.

Width $=$ Relative.

$r=.353 \pm .042$. 
Table I4.

\begin{tabular}{|c|c|c|c|c|c|c|c|c|c|c|c|c|c|}
\hline & & & in & 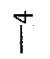 & 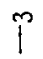 & $\mathfrak{\imath}$ & $\vec{i}$ & 0 & $m$ & $\sim$ & $m$ & + & \\
\hline$X_{1}$ & $\mathrm{Cm}$. & \pm & $\stackrel{2 n}{\pi}$ & 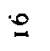 & $\approx$ & $\infty$ & 9 & $\stackrel{i}{i}$ & 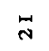 & a & $m$ & $\overline{4}$ & \\
\hline-9 & $48-50$ & 一 & - & - & - & - & 1 & I & $\mathrm{I}$ & - & - & 一 & 3 \\
\hline-6 & $5 \mathrm{I}-53$ & - & 一 & 一 & 3 & 5 & 7 & 8 & 4 & 3 & - & - & 30 \\
\hline-3 & $54-56$ & - & - & $\mathbf{I}$ & 5 & 3 & I3 & I5 & 5 & 2 & I & - & 45 \\
\hline $\mathrm{O}$ & $57-59$ & I & - & - & I & 8 & I 3 & 16 & 3 & 5 & - & - & 47 \\
\hline 3 & $60-62$ & - & - & - & 一 & 3 & I5 & 14 & 6 & I 4 & I & I & 54 \\
\hline 6 & $63-65$ & - & 一 & - & $\mathbf{I}$ & - & 4 & I & 6 & 3 & - & - & I 5 \\
\hline 9 & $66-68$ & - & - & - & - & 一 & - & 3 & 3 & - & - & - & 6 \\
\hline & & m & 0 & $\sim$ & $\stackrel{\circ}{2}$ & 9 & 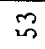 & $\infty$ & $\stackrel{\sim}{\infty}$ & $\approx$ & $n$ & - & \\
\hline
\end{tabular}

Correlation in $25^{0}-14$ a.

Height $=$ Subject.

Number of Branches = Relative.

$r=.240 \pm .045$

Table I5.

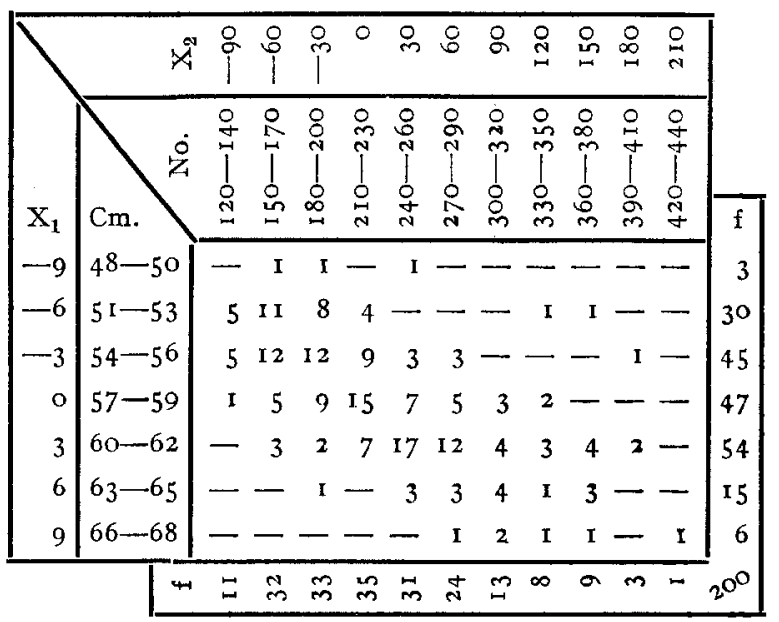

Correlation in $250-14 a$.

Height $=$ Subject.

Number of Seed Pods = Relative.

$\mathrm{r}=.606 \pm .030$. 
Table I6.

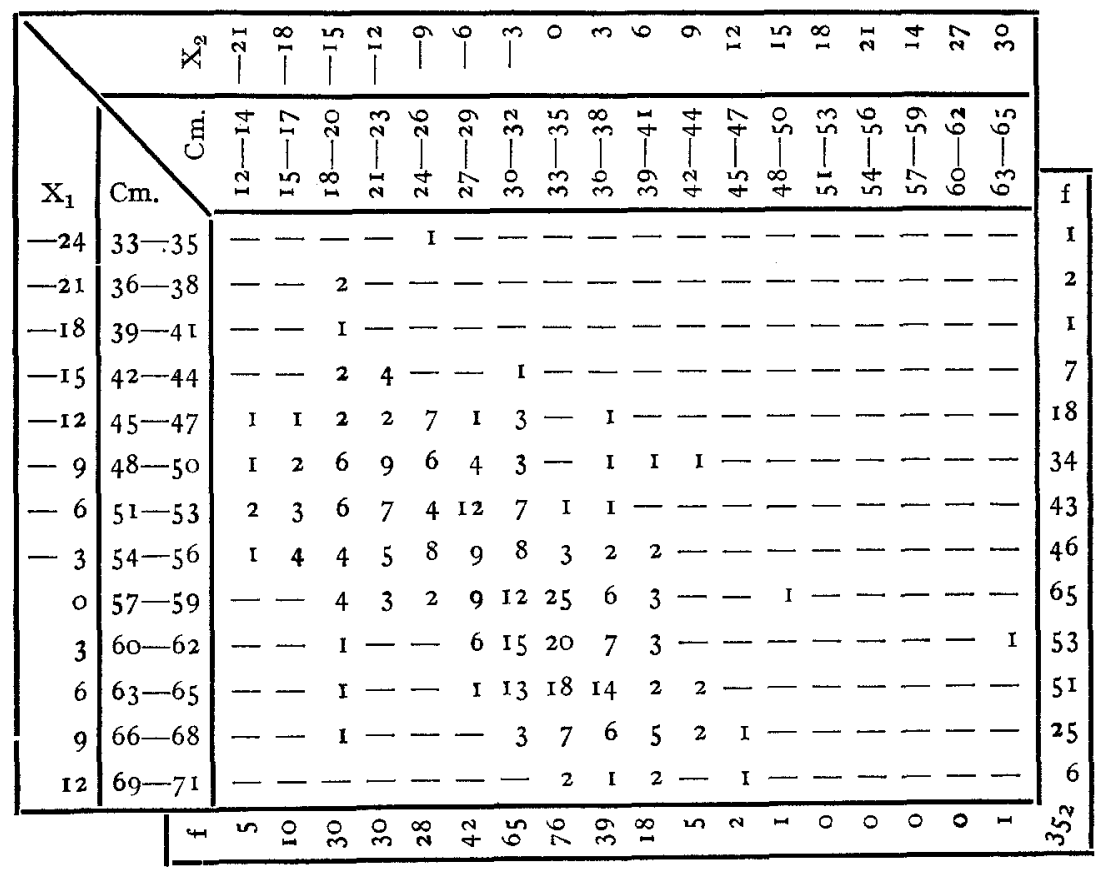

Correlation in $250-16$ a.

Height $=$ Subject.

Width = Relative.

$r=.606 \pm .023$. 
Table I7.

\begin{tabular}{|c|c|c|c|c|c|c|c|c|c|c|c|c|c|c|c|c|c|c|c|c|c|}
\hline & & $\vec{I}$ & & a & $\begin{array}{c}\infty \\
1\end{array}$ & $\mathbf{N}$ & $\begin{array}{l}0 \\
1\end{array}$ & in & $\vec{b}$ & & $m$ & $\begin{array}{l}n \\
1\end{array}$ & $\overline{1}$ & 0 & $r$ & $N$ & $m$ & + & n & 0 & \\
\hline $\mathrm{X}_{1}$ & $\mathrm{Cm}$. & $\infty$ & $a$ & $\stackrel{0}{=}$ & $\Xi$ & $\cong$ & $m$ & \pm & น́ & & 욤 & $\approx$ & $\infty$ & 욤 & in & $\ddot{\sim}$ & n & $\stackrel{m}{w}$ & A & $\stackrel{n}{\sim}$ & $f$ \\
\hline-24 & $33-35$ & 一 & - & 一 & - & - & - & - & - & & - & - & I & - & - & - & - & - & - & 一 & $\mathbf{I}$ \\
\hline$-2 I$ & $36-3^{8}$ & I & $\mathbf{I}$ & 一 & 一 & - & - & - & - & & - & - & 一 & - & - & - & - & - & - & - & 2 \\
\hline$-\mathrm{I} 8$ & $39-4 I$ & 一 & 一 & 一 & - & - & - & - & 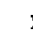 & I & - & 一 & - & - & - & - & - & - & - & - & I \\
\hline -I 5 & $42-44$ & 一 & - & 2 & 2 & I & I & 一 & - & & $I$ & - & - & - & - & - & - & - & - & - & 7 \\
\hline$-\mathrm{I} 2$ & $45-47$ & - & $\longrightarrow$ & 4 & - & 4 & $\mathbf{I}$ & 2 & 2 & 2 & - & 2 & - & I & 2 & - & - & - & - & - & 18 \\
\hline-9 & $48--50$ & - & I & 3 & 4 & 8 & 7 & 6 & - & & I & 2 & I & - & - & - & - & I & - & - & 34 \\
\hline-6 & $5 I-53$ & - & - & 2 & 3 & 10 & $\mathbf{I}$ & 12 & & I & 2 & 2 & 2 & I & 3 & 2 & 2 & - & - & $\ldots$ & 43 \\
\hline-3 & $54-56$ & 一 & - & 2 & 4 & 4 & 8 & 4 & & 3 & 7 & 2 & 3 & 2 & 6 & $\mathbf{I}$ & - & 一 & - & 一 & 46 \\
\hline 0 & $57-59$ & - & - & I & I & 3 & 3 & 8 & & I & - & 4 & 2 & 10 & 10 & I I & 7 & 2 & 2 & - & 65 \\
\hline 3 & $60-62$ & - & - & - & - & - & 1 & - & - & & - & - & 2 & 9 & I 5 & I I & 8 & 6 & I & 一 & 53 \\
\hline 6 & $63-65$ & - & - & - & $\longrightarrow$ & - & I & - & - & & - & - & - & I & I I & I 4 & 14 & 9 & $\mathbf{I}$ & 一 & $5 I$ \\
\hline 9 & $66-68$ & - & 一 & - & - & - & - & I & - & & - & - & I & 2 & 6 & 5 & 7 & 2 & - & I & 25 \\
\hline 12 & $69-71$ & - & 一 & - & - & - & - & - & - & & - & - & - & I & 2 & - & 2 & I & - & 一 & 6 \\
\hline & & $\mapsto$ & c & \pm & $\Xi$ & $\stackrel{\circ}{m}$ & $m$ & $m$ & & & 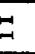 & 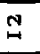 & 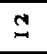 & $\hat{N}$ & in & 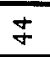 & & 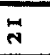 & + & - & $33^{4}$ \\
\hline
\end{tabular}

Correlation in $250-16 \mathrm{a}$.

Height $=$ Subject.

Number of Branches = Relative.

$T=.698 \pm .018$. 
Table I8.

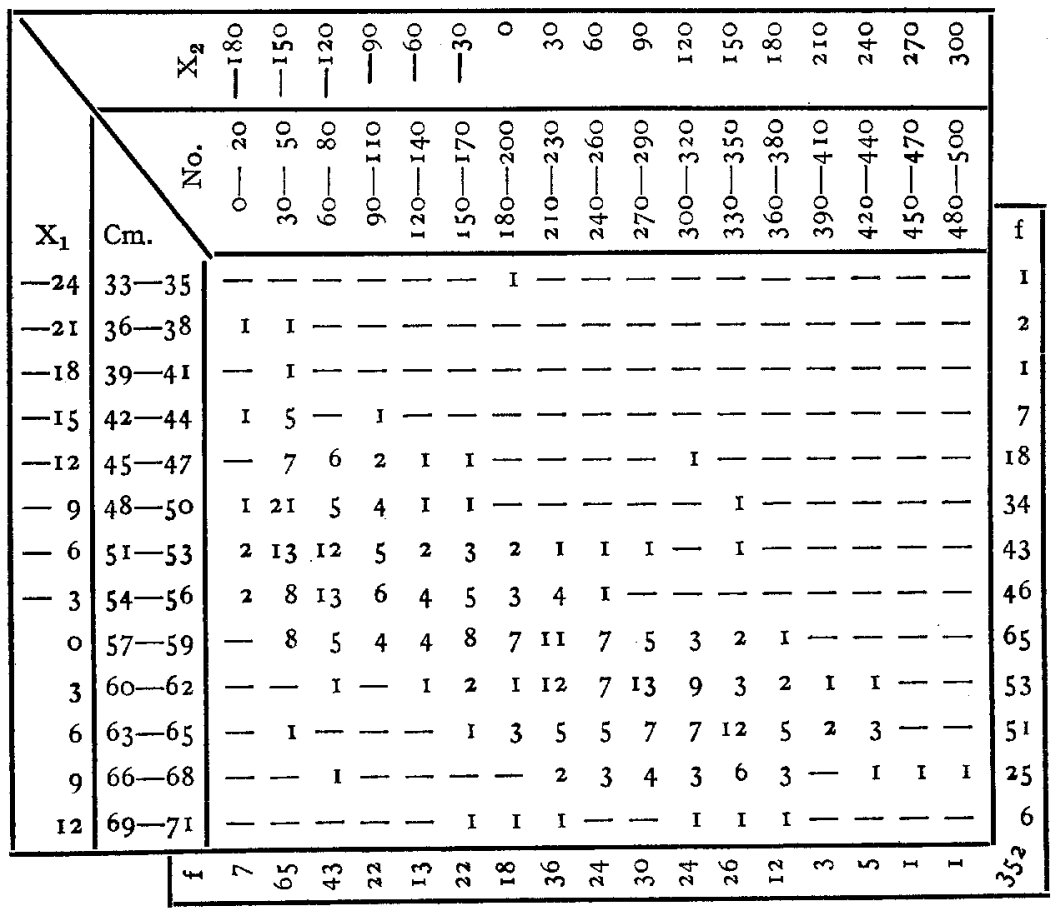

Correlation in $250-16$ a.

Height $=$ Subject.

Number of Seed Pods = Relative.

$x=.726 \pm .017$. 
Table rg.

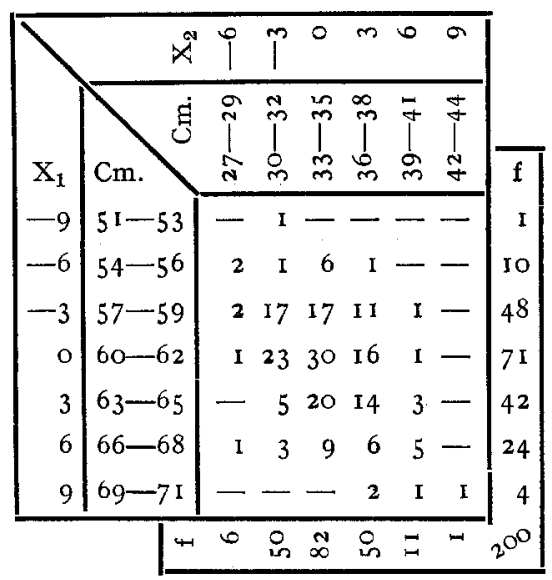

Correlation in $250-20$ a.

Height $=$ Subject.

Wid th = Relative.

$\mathbf{r}=.346 \pm .042$.

Table 20.

\begin{tabular}{|c|c|c|c|c|c|c|c|c|c|c|}
\hline & & 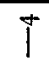 & $\tilde{i}$ & & $\overrightarrow{1}$ & 0 & - & $N$ & $m$ & \\
\hline$x_{1}$ & $\mathrm{Cm}$. & 0 & 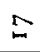 & $\stackrel{\infty}{+\infty}$ & or & 요 & $\vec{N}$ & N & $\ddot{N}$ & $f$ \\
\hline-9 & $51-53$ & 一 & - & - & 一 & - & - & I & 一 & I \\
\hline-6 & $54-5^{6}$ & - & 1 & 1 & - & 4 & I & 3 & - & ro \\
\hline-3 & $57-59$ & I & 2 & 6 & 8 & I9 & 7 & 4 & 1 & 48 \\
\hline o & $60-62$ & I & 2 & 6 & 19 & 24 & I 4 & 5 & - & 71 \\
\hline 3 & $63-65$ & - & I & 4 & 6 & I 5 & IO & 6 & - & 42 \\
\hline 6 & $66-68$ & 一 & - & I & 2 & IO & 7 & 2 & 2 & 24 \\
\hline 9 & $69-71$ & - & - & - & 2 & I & I & - & - & 4 \\
\hline & & $N$ & $\infty$ & $\stackrel{\infty}{\sim}$ & $m$ & $m$ & q & $\vec{a}$ & $m$ & 200 \\
\hline
\end{tabular}

Correlation in $250-202$.

Height $=$ Subject.

Number of Branches = Relative.

$r=.103 \pm .047$. 
Table 2I.

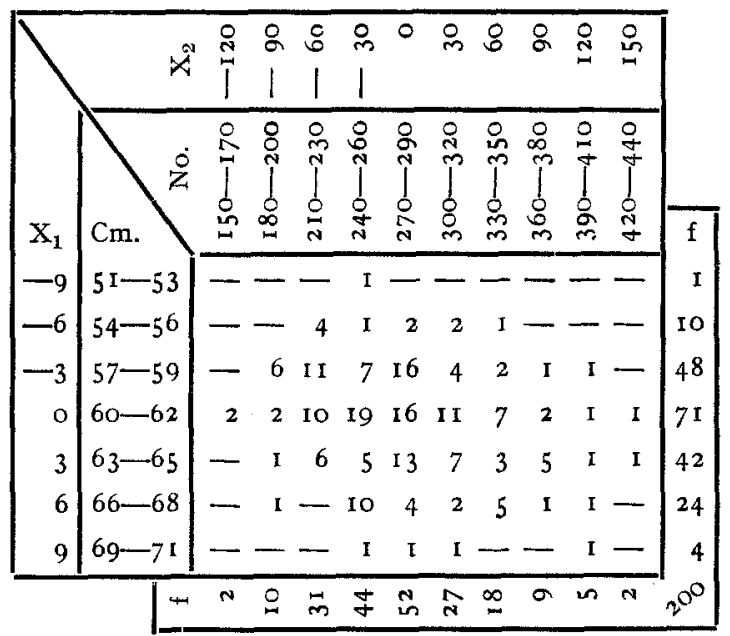

Correlation in $250-20 a$.

Height $=$ Subject.

Number of Seed Pods = Relative.

$r=.225 \pm .045$.

Table 22.

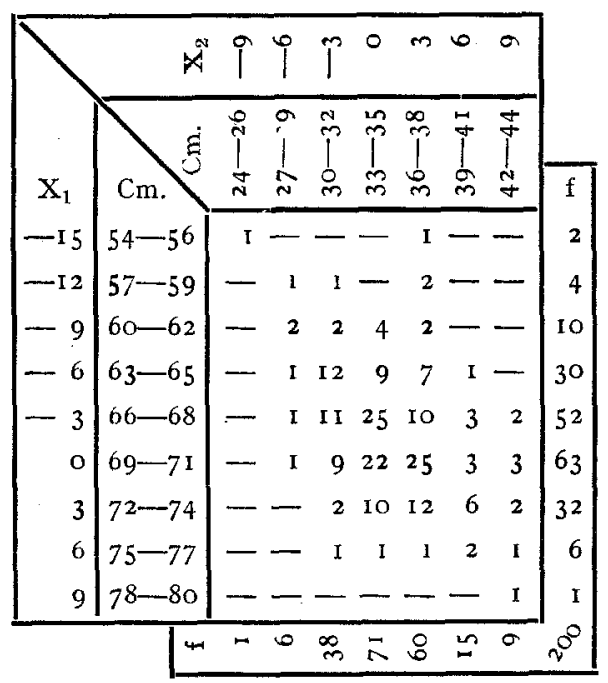

Correlation in $250-I I$ a.

Height $=$ Subject.

Width $=$ Relative.

$r=.384 \pm .04 \mathrm{I}$. 
Table 23.

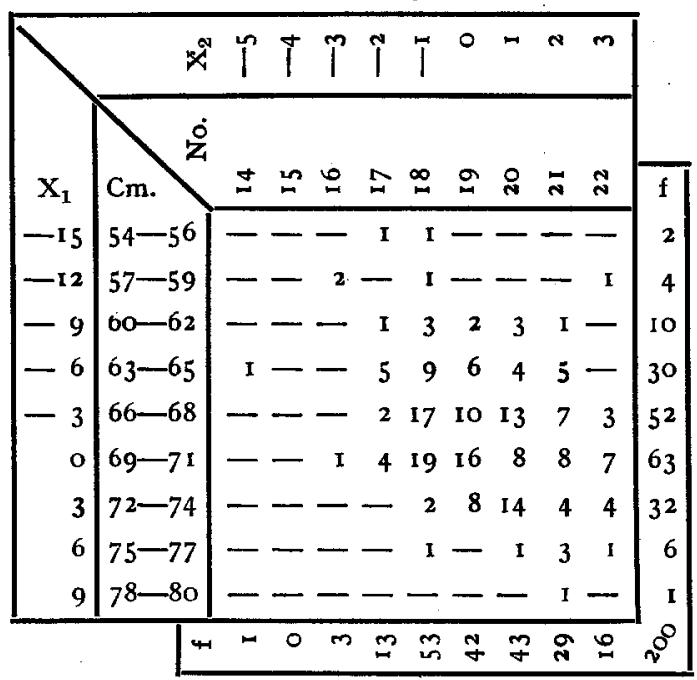

Correlation in $250-$ I I a.

Height $=$ Subject.

Number of Branches = Relative.

$\mathrm{I}=.3 \mathrm{II} \pm .043$.

Table 24 .

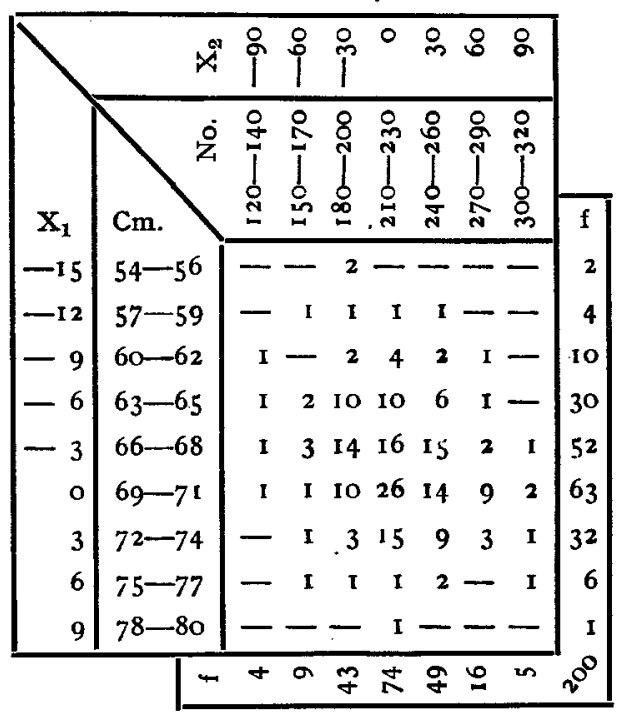

Correlation in 250-I I a.

Height $=$ Subject.

Number of Seed Pods = Relative.

$\mathbf{r}=.225 \pm .045$. 
Table 25 .

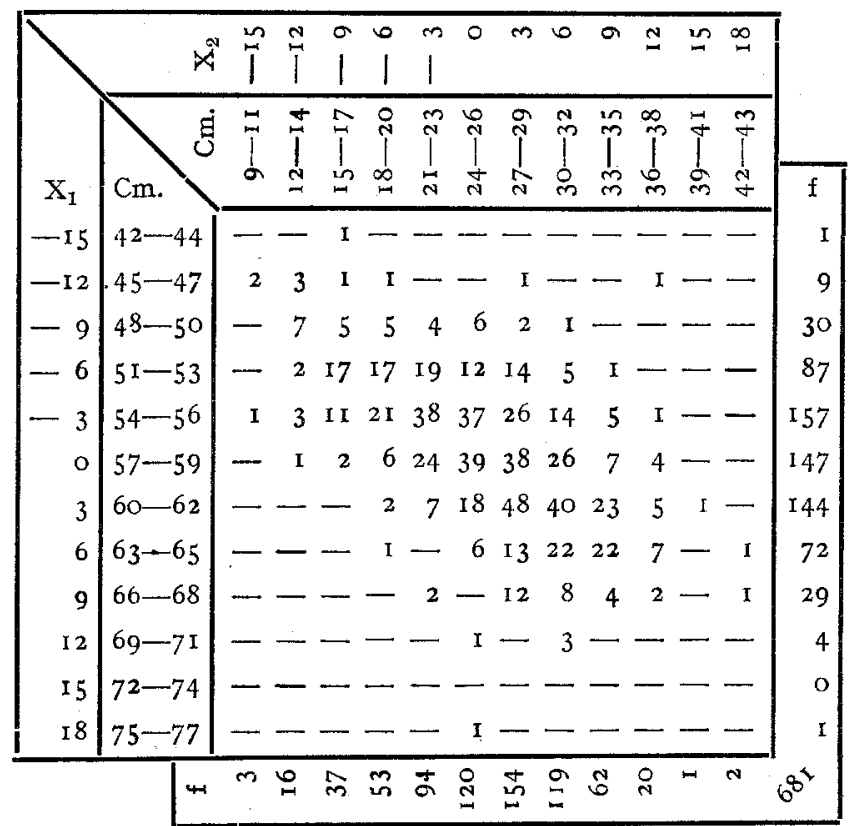

Correlation in 250-II u, 250-IIV, 250-II w, 250-IIX, 250-IIy and $250-I I z$.

Height $=$ Subject.

Width = Relative.

$\mathbf{r}=.590 \pm .017$ 
Table 26.

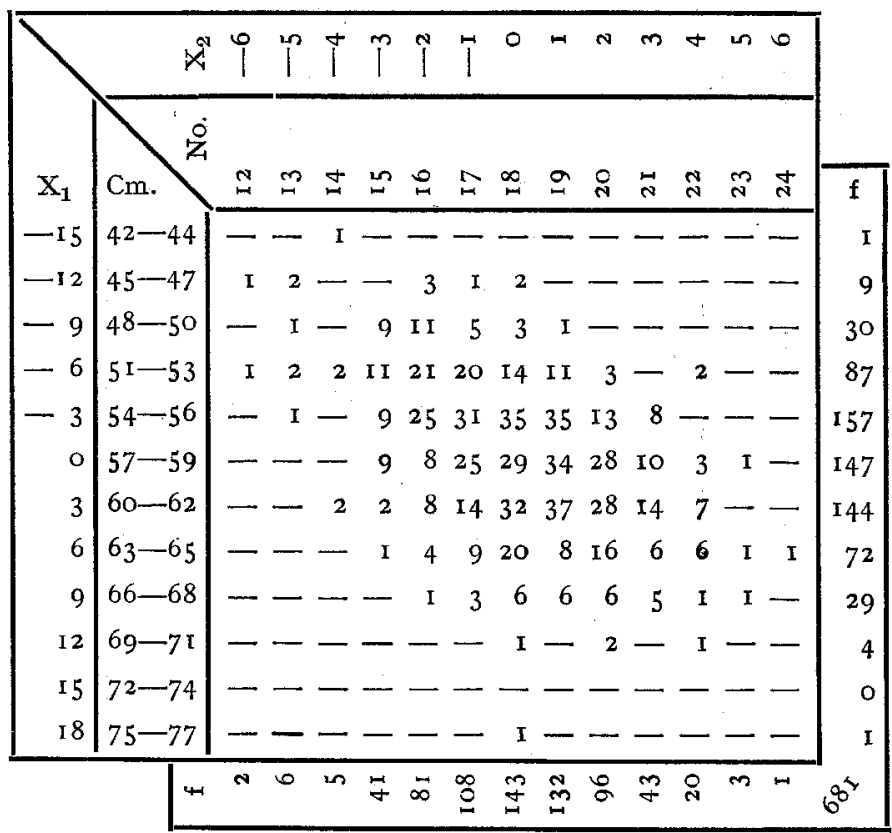

Correlation in $250-$ II, $250-$ IIV, 250-II $, 250-I I X, 250-$ I I and $250-I I z$.

Height $=$ Subject.

Number of Branches = Relative.

$\mathbf{r}=.447 \pm .02 \mathrm{I}$ 
226 Humbert, A quantitative Study of Variation, Natural and Induced, etc.

Table 27.

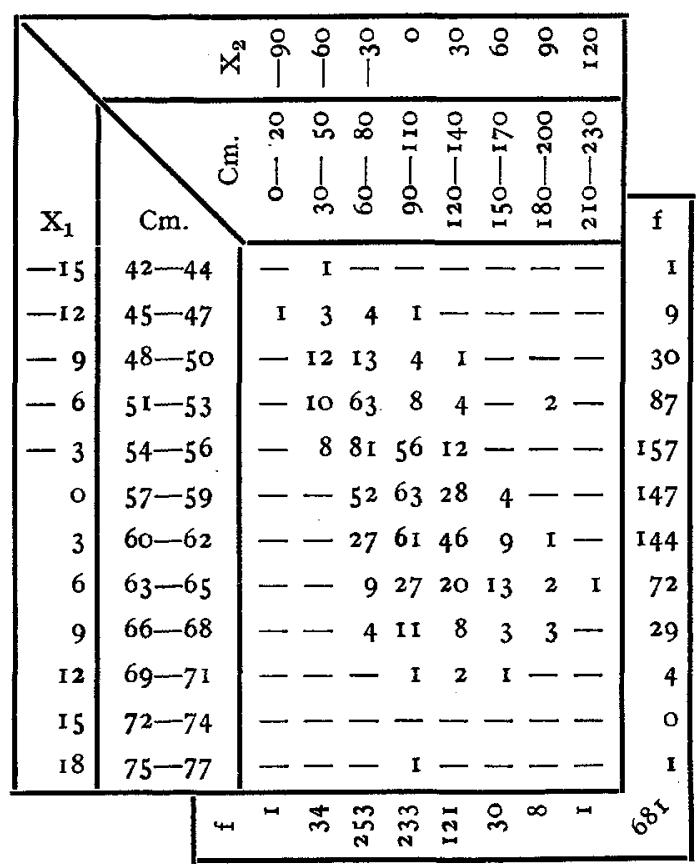

Correlation in $250-I \mathrm{Iu}, 250-I \mathrm{IV}, 250-\mathrm{IIW}, 250-\mathrm{IIX}, 250-\mathrm{IIy}$ and $250-1 \mathrm{Iz}$.

Height $=$ Subject.

Number of Seed Pods $=$ Relative.

$r=.539 \pm .018$. 